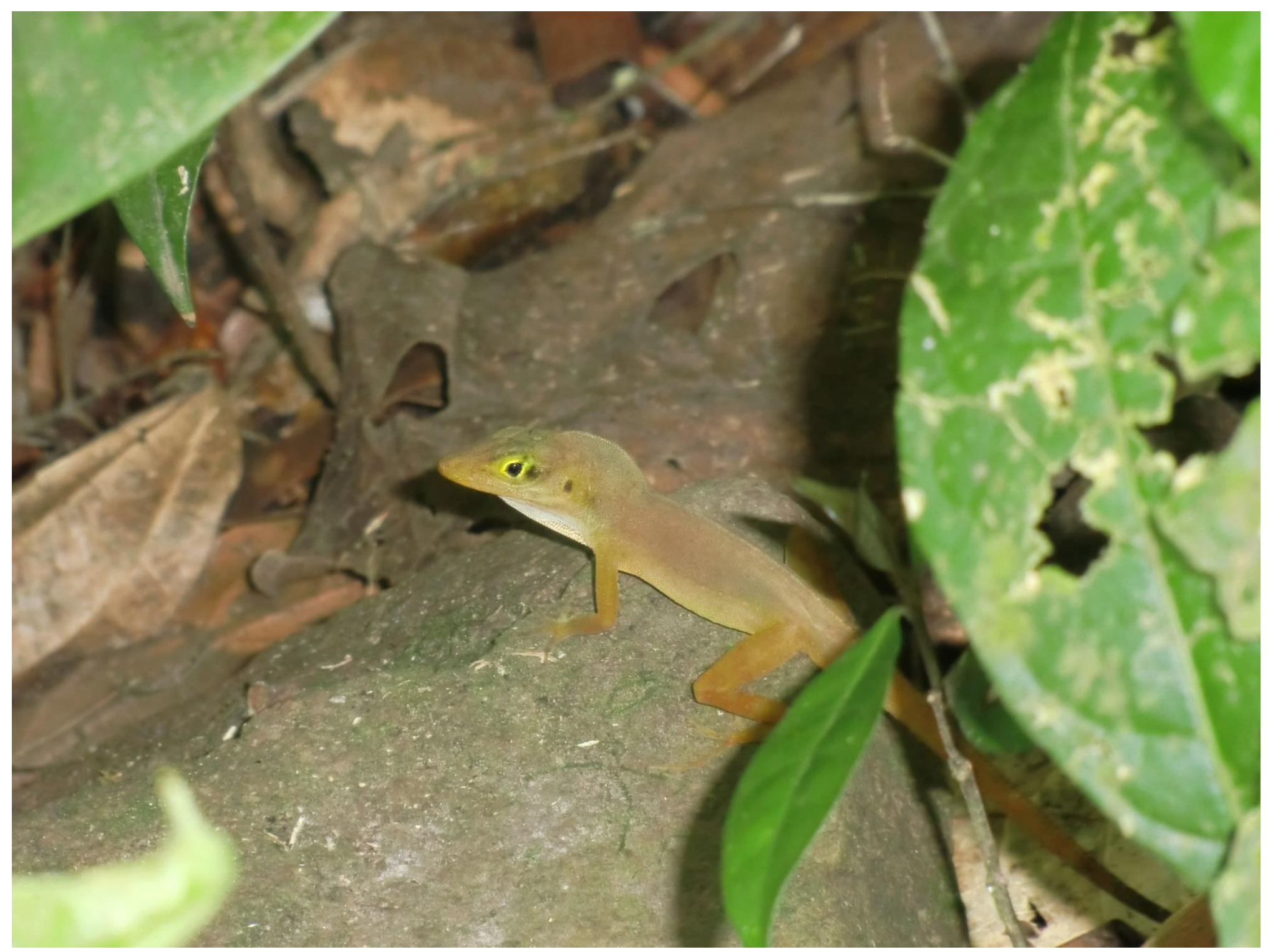

Preliminary checklist of extant endemic species and subspecies of the windward Dutch Caribbean (St. Martin, St. Eustatius, Saba and the Saba Bank) 


\section{Preliminary checklist of extant endemic species and subspecies of the windward Dutch Caribbean (St. Martin, St. Eustatius, Saba and the Saba Bank)}

Authors:

O.G. Bos ${ }^{1}$, P.A.J. Bakker², R.J.H.G. Henkens ${ }^{3}$, J. A. de Freitas ${ }^{4}$, A.O. Debrot $^{1}$

1. Wageningen Marine Research

2. Naturalis Biodiversity Center

3. Wageningen Environmental Research

4. Carmabi

Publication date:

This research project was carried out by Wageningen Marine Research at the request of and with funding from the Ministry of Agriculture, Nature and Food Quality for the purposes of Policy Support Research Theme 'Caribbean Netherlands' (project no. BO-43-021.04-012).

Wageningen Marine Research

Den Helder, October 2018

CONFIDENTIAL no

Wageningen Marine Research report C067/18

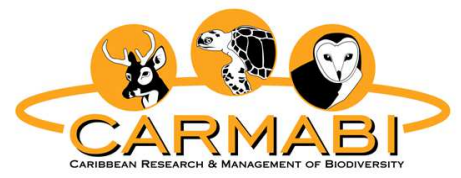


Bos OG, Bakker PAJ, Henkens RJHG, De Freitas JA, Debrot AO (2018). Preliminary checklist of extant endemic species of St. Martin, St. Eustatius, Saba and Saba Bank. Wageningen, Wageningen Marine Research (University \& Research centre), Wageningen Marine Research report C067/18

Keywords: endemic species, Caribbean, Saba, Saint Eustatius, Saint Marten, Saba Bank

Cover photo: endemic Anolis schwartzi in de Quill

crater, St Eustatius (photo: A.O. Debrot)

Date: $18^{\text {th }}$ of October 2018

Client: $\quad$ Ministry of LNV

Attn.: H. Haanstra

PO Box 20401

2500 EK The Hague

The Netherlands

BAS code BO-43-021.04-012 (KD-2018-055)

This report can be downloaded for free from https://doi.org/10.18174/460388

Wageningen Marine Research provides no printed copies of reports

Wageningen Marine Research is ISO 9001:2008 certified.

(C) 2018 Wageningen Marine Research Wageningen UR

Wageningen Marine Research institute of Stichting Wageningen Research is registered in the Dutch traderecord nr. 09098104, BTW nr. NL 806511618
The Management of Wageningen Marine Research is not responsible for resulting damage, as well as for damage resulting from the application of results or research obtained by Wageningen Marine Research, its clients or any claims related to the application of information found within its research. This report has been made on the request of the client and is wholly the client's property. This report may not be reproduced and/or published partially or in its entirety without the express written consent of the client. 


\section{Contents}

$\begin{array}{lr}\text { Summary } & 5\end{array}$

$\begin{array}{llr}1 & \text { Introduction } & 7\end{array}$

$\begin{array}{lll}1.1 & \text { Scope and objective } & 7\end{array}$

1.2 Endemic taxa in the Caribbean Netherlands $\quad 8$

1.3 Vulnerability of endemic taxa (species and subspecies) 9

1.4 Potential endemics and lost endemics 9

$\begin{array}{llr}1.5 & \text { Dutch Caribbean Species Register } & 10\end{array}$

$2 \quad$ Materials and Methods $\quad 13$

2.1 Endemics $\quad 13$

$\begin{array}{ll}2.1 .1 & \text { Definitions } \\ 2.1 .2 & 13\end{array}$

$\begin{array}{ll}2.1 .2 & \text { Identification of endemics } \\ & 13\end{array}$

2.1.3 Identification of potential endemic species $\quad 15$

$\begin{array}{lll}2.1 .4 & \text { New species } & 16\end{array}$

2.1.5 Geographical regions 16

$\begin{array}{ll}2.1 .6 & \text { Additional sources of information }\end{array}$

2.2 Conservation Status 20

$\begin{array}{llr}3 & \text { Results } & \mathbf{2 1}\end{array}$

3.1 Total number of endemic taxa for the SSS islands and the Saba Bank 21

3.2 Species and subspecies $\quad 21$

$\begin{array}{ll}3.3 & \text { Marine versus terrestrial endemic taxa }\end{array}$

$\begin{array}{lll}3.4 & \text { Endemics of the SSS islands and Saba Bank } & 23\end{array}$

$\begin{array}{ll}3.5 & \text { New species for the SSS islands and Saba Bank }\end{array}$

3.5.1 Fish 26

$\begin{array}{lll}3.5 .2 \text { Corals } & 26\end{array}$

$\begin{array}{lll}3.5 .3 & \text { Sponges } & 27\end{array}$

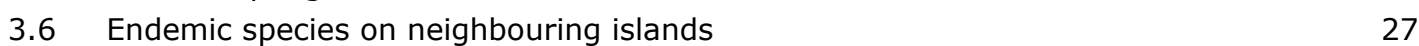

3.7 Endemic taxa (species and subspecies) per species group 32

3.7.1 Worms (Annelids-polychaetes)

3.7.2 Arthropods (Arthropoda) $\quad 32$

3.7.3 Bony fish (Chordata - Actinopterygii) $\quad 35$

$\begin{array}{lll}3.7 .4 & \text { Birds (Chordata - Aves) } & 35\end{array}$

3.7.5 Amphibians (Chordata - Amphibia) $\quad 35$

3.7.6 Sharks, rays (Chordata - Chondrichthyes) 36

3.7.7 Mammals (Chordata - Mammalia) 36

3.7.8 Reptiles (Chordata - Reptilia) 36

3.7.9 Anemones, hydrozoans, corals and jellyfish (Cnidaria) 37

3.7.10 Bivalves, snails, squid, chitons and tusk shells (Mollusca) 37

$\begin{array}{lll}3.7 .11 & \text { Flatworms (Platyhelminthes) } & 38\end{array}$

$\begin{array}{ll}3.7 .12 & \text { Sponges (Porifera) } \\ 3.7 .13 & 38\end{array}$

3.7.13 Wheel animals (Rotifera) 38

3.7.14 Red algae, green algae and vascular plants (Plantae) 39

$\begin{array}{ll}3.8 & \text { IUCN Conservation status }\end{array}$

4 Conclusions and recommendations $\quad 41$

$4.1 \quad$ Number of endemics $\quad 41$

$\begin{array}{lll}4.2 & \text { Potential endemics } & 42\end{array}$ 
$\begin{array}{lll}4.3 & \text { IUCN Conservation status } & 42\end{array}$

4.4 Research priorities and recommendations 42

$5 \quad$ Acknowledgements $\quad 44$

$6 \quad$ Quality Assurance $\quad 45$

$\begin{array}{lr}\text { References } & 46\end{array}$

$\begin{array}{lr}\text { Justification } & \mathbf{5 0}\end{array}$

Annex 1: Numbers of endemics of SSS islands and Saba Bank 51

Annex 2: Endemic species list of SSS islands and Saba Bank 56

Annex 3: Conservation status of species of the SSS islands and Saba Bank 62 


\section{Summary}

Endemic species and subspecies (or "taxa" for short) having restricted geographic distributions are an extremely important feature of biodiversity and a key criterion to conservation valuation and nature management goal-setting. Saba, St. Eustatius and St. Martin (the Dutch SSS islands) form part of the Caribbean biodiversity hotspot region but up to now no systematic assessment was available on the occurrence of endemic animals and plants on these islands and in the surrounding marine areas (incl. Saba Bank). We here provide such a preliminary assessment as an aid to conservation and nature management, and to help in prioritizing future research. Our assessment shows that the SSS islands and Saba Bank together possess 223 endemic animals and plants (32 subspecies, 191 species), of which 35 are endemic to the SSS islands or Saba Bank, 15 are endemic to the Northern Lesser Antilles (Virgin Islands southwards up to and including Montserrat, including St Kitts Bank and Anguilla Bank endemics), 110 to the Lesser Antilles (Virgin Islands southwards up to and including Grenada) and 58 to the joint Antilles (Lesser and Greater Antilles). Of the 35 island endemics, 8 are marine, 26 are terrestrial and 1 is from brackish water.

The breakdown of the 223 endemic species and subspecies according to larger taxonomic groupings is as follows: Worms (Polychaeta): 1; Spiders, scorpions and pseudoscorpions (Arachnida): 23; Copepods (Hexanauplia): 2; Beetles (Coleoptera): 33; Flies (Diptera): 4; True bugs (Hemiptera):3 ; Sawflies, wasps, bees, and ants (Hymenoptera): 3; Butterflies and moths (Lipidoptera): 12; Dragonflies and damselflies (Odonata): 1; Grasshoppers, locusts and crickets (Orthoptera): 22; Amphipods: 1; Crabs, lobsters and shrimps (Decapoda): 1; Isopoda: 1; Pycnogonida: 1; Bony fish (Actinopterygii): 4; Sharks and rays (Chondrichthyes): 1; Birds: 23; Amphibians: 1; Mammals (bats): 5; Reptiles: 16; Cnidarians: 5; Bivalves: 5; Gastropods: 28; Flatworms (Platyhelminthes) 1; Red Algae: 3; Spermatophyta (Vascular plants): 22.

The breakdown of the 35 taxa that are endemic to the SSS islands or Saba Bank is as follows: Polychaeta: 1; Arachnida: 4; Hexanauplia: 2; Coleoptera: 3; Diptera: 1; Hemiptera: 1; Orthoptera: 10; Bony fish: 2; Reptiles: 3; Bivalves: 1; Gastropods: 3; Red Algae 1; Vascular plants: 3.

The breakdown in numbers of island endemics for the SSS islands and Saba Bank is:

- St. Martin: 12 island endemics (10 animal species and 2 plant species)

- St. Eustatius: 10 island endemics: (8 animals species and 2 plant species)

- Saba: 10 island endemics: (10 animals species, 0 plant species).

- Saba Bank: 3 endemics ( 3 animal species, 0 plant species)

The number of endemics is probably larger than reported here. Very little marine taxonomic research has been conducted in the SSS islands and many species probably remain to be described. In the past decade many new and potentially endemic species (of algae, fish, corals, sponges, etc.) have been discovered, mainly on the Saba Bank. Furthermore, additional research on specific species groups (e.g. beetles) could result in the discovery of yet more new endemic species.

The IUCN assesses the conservation status of plant and animal species worldwide. Most rare and endangered island endemics are not included in the assessments due to lack of information or perceived priority. Therefore, most IUCN-listed threatened species for the SSS islands are species with much wider distributions. Assessments are only available for 42 of the endemic (sub)species of the SSS islands. The only recent endemic ground-dwelling mammal, the Nevis rice rat, is extinct. The endemic bats and bird subspecies have wider dispersal capabilities and currently carry no IUCN threatened listing, eventhough several only survive in tiny, scattered and vulnerable populations. Only the following six endemic terrestrial reptiles currently carry a IUCN threatened status:

- Critically Endangered: Lesser Antillean Iguana (Iguana delicatissima).

- Endangered: Anguilla Bank Racer (Alsophis rijgersmaei); Spondylurus powelli.

- Vulnerable: Saba Racer (Alsophis rufiventris) and Anguilla Bank Bush Anole (Anolis pogus).

- Near threatened: St. Christopher Ameiva (Pholidoscelis erythrocephalus). 
Many of the 223 endemic taxa listed here are restricted to very small populations on one or only a few small islands. This makes them very vulnerable to extinction. Indeed, in the recent past, some species may already have become extinct (e.g. two endemic plants known only from St. Martin). Therefore, assessments of the conservation status of each of the identified endemic taxa are urgently needed for the SSS islands and Saba Bank. In addition, conservation strategies need to be developed to minimize extinction risk for the most endangered endemics. 


\section{Introduction}

\subsection{Scope and objective}

The Convention on Biological Diversity (CBD) requires member states to identify (and monitor) important components of biodiversity, such as ecosystems or habitats containing high numbers of endemics. Endemic species which have a highly restricted distributional range represent a unique contribution of any particular region to global biodiversity. Endemic species are often abundant on or around islands due to the fact that populations of organisms inhabiting such areas may have been isolated from other populations for longer periods of time, allowing them to develop unique traits. Islands play an important role in generating (as "cradle") but also conserving (as "museum") biodiversity worldwide (Gascuel et al. 2016). As a consequence of a limited distributional range, and the development of "island naiveté", whereby species lose competitive and anti-predator skills (Lomolino et al. 2017), such island endemics are typically extra vulnerable to extinction (e.g. Biber 2002, Kouvari et al. 2018, Leclerc et al. 2018). Consequently, identification of endemic taxa is critical for the formulation of nature conservation and management policy.

So far, identification of species that are endemic to the Caribbean Netherlands is largely restricted to the Leeward Dutch Caribbean (Aruba, Bonaire, Curaçao) for which an inventory of species has been made (Debrot 2006), and to which imported updates have been recently added (Debrot et al. 2018). For the Windward Caribbean islands of the Kingdom, no systematic effort has yet been undertaken to assemble a list of endemic (sub)species. This is dearly needed both to fulfil the requirements of the CBD and as a contribution towards the new 2018 Nature Policy Plan, which is currently being drafted for the Caribbean Netherlands. For this, a complete and up to date list of endemic species is needed for Saba and St. Eustatius, as well as St. Maarten, because of its close biogeographical connection while also being part of the Kingdom of the Netherlands.

The term endemism or "endemic" refers to species possessing a limited geographic range. The term is hence geographically defined. For this assignment we inventory all species that are exclusively known to occur on the islands of Saba, St. Eustatius or St. Martin (so-called "island endemics") or are limited to a small area of the Lesser Caribbean chain of islands around Saba, St. Eustatius or St. Maarten. The assignment is not restricted only to the three mentioned Dutch islands but also includes endemics from nearby or neighbouring islands. This is because in the geological past (e.g. in the Pliocene and Pleistocene) several of these islands were connected to form larger islands as a result of lower sea level. This was for instance the case with St. Eustatius and St. Kitts. This means that species that today are endemic to St. Kitts are likely to have occured on St. Eustatius in the past, or may even be present on St. Eustatius. As such, these (lost) endemic species should be actively searched for and should also be seriously considered as important candidates for biodiversity restoration. Likewise, species endemic to St. Eustatius and only known so far from this island are likely candidates for having or having had populations on St. Kitts. Identification of endemic species is the starting point after which conservation status of each endemic species can be determined and subsequent conservation/restoration measures can be identified to protect the most critically endangered endemic species.

The objective is to produce an overview of existing, current and potential, terrestrial and marine, endemic species of plants and animals for the windward islands of the Dutch Caribbean (Saba, St. Eustatius, St. Martin, Saba Bank; further referred to as the SSS-islands). 


\subsection{Endemic taxa in the Caribbean Netherlands}

The Caribbean region is considered as a biodiversity hotspot because of the relatively high level of endemism (BEST 2016). At least 7,500 endemic plant species and 880 vertebrates are known for this region that features an exceptional array of ecosystems, from coral reefs, seagrass beds, mangroves to tropical rainforests, dry seasonal forests or cactus scrublands (BEST 2016).

As indicated, endemism is a geographically defined term. It is therefore necessary to be explicit about what geographic scales are being used to denote the level of species sharing. In this report we distinguish the following levels of endemism (Table 3 and Table 4).

a) Island level endemic species: species with a distribution that is restricted to only one of the SSS islands or Saba Bank.

b) Bank level endemic species: species occurring on one or more islands that formed a single island in the prehistoric past with one of the SSS islands.

c) Northern lesser Antilles level endemic species: species found on one or more of the SSS islands that are restrictively shared with the islands from Puerto Rico to and including Montserrat. This includes all inter-lying islands and banks such as St. Croix, the Saba Bank, Anguilla Bank and the St. Kitts Bank islands.

d) Lesser Antilles level endemic species: species found on one or more of the SSS islands that are restrictively shared with the islands of the Lesser Antilles (all islands between Anguilla and including Grenada).

e) Antilles level endemic species: species found on one or more of the SSS islands that are restrictively shared with the islands of up to the Greater Antilles (all islands between and including Cuba. The Bahamas and Turks and Caicos are excluded).

f) 'Other level' endemic species: species found at regions larger than the Antilles (Table 3 and Table 4).

Endemic species occuring the SSS islands, but which are occuring beyond the above mentioned levels were not distinguished from other Western Atlantic endemic species, West Indianendemic species or circumtropical species. Hence, on this basis, the widely ranging endangered endemic West Indian manatee, Trichechus manatus manatus, was not included in this overview of endemic taxa even though it has been recently documented for St. Martin (Debrot et al. 2006).

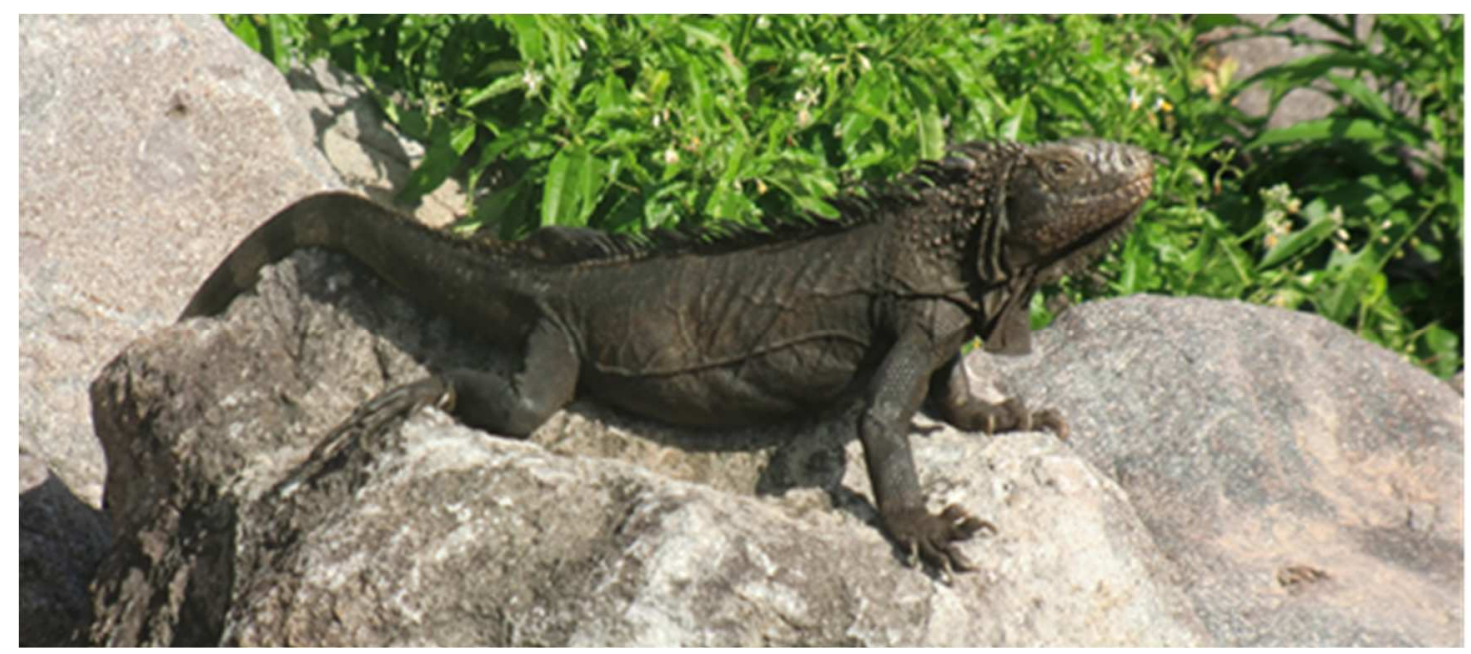

Figure 1. A virtually black female Saba Island Green Iguana, Iguana iguana, at the foot of Bunker Hill, Saba (photo: A. Debrot).

Measures of endemism at the species or subspecies level are of course minimalistic by nature (Myers et al. 2000) and provide only part of the total biodiversity picture. Therefore, it must be kept in mind that a great deal of the unique biodiversity present in an area is not necessarily expressed at the species or subspecies level, but at the level of the localized population at an island. One example that illustrates this point is the melanistic Green iguana, Iguana iguana, living on Saba which is considered 
to be a separate lineage within the green iguana (Brueil 2013, Stephen et al. 2013) (Figure 1). It has as yet not been described as an endemic species or subspecies but does represent an endemic genetic lineage which may ultimately be described as a separate species or subspecies.

Many of the taxa (species and subspecies) listed in this report are poorly described (little information is known on their taxonomic status, ecology, etc.) and may require a systematic revision. This could affect their species status. Consequently, the endemic taxa recorded in the preliminary list presented in this report, is only indicative and most certainly incomplete, but should provide a useful starting inventory. As more and more research becomes available, the known distributional ranges for the taxa listed in this report may change. This may affect whether or not they are to be considered "endemic".

Checklists of endemic taxa are dearly needed for biodiversity conservation purposes, because endemism is a special aspect of biodiversity. It refers to the narrow distributional range of certain species that can be considered "unique" to that area. Endemic species having a restricted regional distribution are an extremely important feature of biodiversity and a key criterion to conservation valuation and nature management goal-setting. Due to a limited distribution range, small total population size, and low genetic diversity, endemic species are extra vulnerable to extinction. The Dutch SSS islands form part of the Caribbean biodiversity hotspot region (Myers et al. 2000), but up to now, no systematic assessment was available on the occurrence of endemic species on these islands and the surrounding marine areas. Scattered information is available, such as the biological inventories of St. Martin, St. Eustatius and Saba (Rojer 1997abc) and inventories by the EU BEST programme (BEST 2016), which suggest that there should be a considerable number of endemic species on or within the territory of these islands.

\subsection{Vulnerability of endemic taxa (species and subspecies)}

In the BEST programme (BEST 2016), endemic and restricted-area species have been used to help identify Key Biodiversity Areas (KBAs) that are in need of protection. Because endemic species have such a restricted distribution and because they are often ecologically "naive" (Lomolino et al. 2017), they can easily become extinct if they, or their habitat ranges are threatened. Threats include the introduction of new species (rats, cats, goats, raccoons, mongoose, invasive plants), habitat destruction (e.g. coastal development) or consumption (e.g. iguanas) (Rojer 1997abc; BEST 2016). In the West Indies, $80 \%$ of extinctions of species have been caused principally by biological invasions (Leclerc et al. 2018) and the West Indies continue to remain a "hotspot" of insular extinction threat (Leclerc et al. 2018). Another threat to the survival of endemic species is climate change and its impacts in the region. At the same time due to the lack of ecological knowledge a lot of threats and impacts on e.g. population size of endemic species are not clear yet.

\subsection{Potential endemics and lost endemics}

During the last ice age (Last Glacial Maximum, ending 20,000 y BP) global sea level was approximately 120-135 m lower than today (Clark \& Mix 2002). As a result, in the past several of theSSS islands were connected to other islands to form one larger island (Rojer 1997a). In Figure 4 this is illustrated: taking the $-100 \mathrm{~m}$ isobath as a reference level, we assume that the following island groups formed larger islands:

- Anguilla Bank: St. Martin, Anguilla and St. Barthélemy

- $\quad$ St. Kitts Bank: St. Eustatius, St. Kitts and Nevis 
Note that Figure 4 also shows that Saba and Saba Bank are surrounded by deep waters and as a result were also isolated from eachother during the last ice age.

Species endemic to islands that were connected to the SSS islands in the past, but not occuring on the SSS islands anymore due to local extirpation, should still be considered as an authentic part of the endemic flora or fauna of the SSS islands.

Likely candidates for authentic endemic species which are possibly no longer present or which have not yet been documented on the SSS islands, are small species in groups such as terrestrial reptiles, non-flying insects and terrestrial molluscs that are characterised by limited dispersal capacities. For species groups that disperse through air or water, such as flying insects, crabs, lobsters, molluscs, birds, bats and fish it is expected that the sea forms no strict barrier for migration..

Endemic species which no longer exist, such as the giant ground sloth Amblyrhiza inundata, of St. Martin, Anguilla and St. Barths (McFarlane et al. 2014) and the St. Eustatius rice rat Pennatomys nivalis, which formerly was also found on the other islands of the St. Kitts Bank (Brace et al., 2015), have been excluded. While such species are very interesting from the viewpoint of biodiversity evolution, they are no longer of relevance to biodiversity conservation, which is the main underlying reason for this work.

Species can also be lost due to hybridization. The Lesser Antillean iguana, Iguana delicatissima, that until recently occurred on St. Maarten, but which has been lost due to hybridization with the introduced invasive green iguana, Iguana iguana (Van den Burg et al. 2018). Hence, even though I. delicatissima no longer exists on St. Maarten, it still should be considered an authentic endemic species of that island. Such species have been included as endemic species of a particular island or island group.

\subsection{Dutch Caribbean Species Register}

Many different publications have described the flora and fauna on the Dutch Caribbean islands (Aruba, Bonaire, Curaçao, Saba, Saint Eustatius, Saint Martin) and Saba Bank. They were brought together in 2017 in the online Dutch Caribbean Species Register (DCSR) by Naturalis Biodiversity Center (Figure 2). The register is based on $>1000$ publications (scientific papers, field guides, reports, etc.) and focuses on both terrestrial and marine species, but not specifically on endemics. Although a lot of information is present in the species register, the list of endemic species was therefore not yet complete at the start of this project (July 2018). For example, in July 2018 only 7 island endemics (species or subspecies exclusively present on Saba, Saint Eustatius, Saint Martin or the Saba Bank) were listed in the DSCR. Furthermore, 50 (sub)species endemic on the level of the Leeward Antilles were listed, as well as 19 (sub)species on the level of the Lesser Antilles, and 1 on the level of the West Indies (Figure 3.4), totalling only 58 endemic species at different geographical levels. This project was done to allow an update of the DCSR.

The register can be found on https://www.dutchcaribbeanspecies.org/. To find island endemic species in the Species Register, go to https://www.dutchcaribbeanspecies.org/, and click on: Search > Extensive Search $>$ Filter search $>$ Presence and Distribution $>$ Endemic to $>$ [name island]:

- $\quad$ Sint Maarten (reffered to as St. Martin throughout this report)

- $\quad$ Sint Eustatius

- Saba

- Saba Bank 
N Dutch Caribbean Species Register

Overview of the biodiversity of Aruba, Bonaire, Curaçao, Saba, Sint Eustatius and Sint Maarten

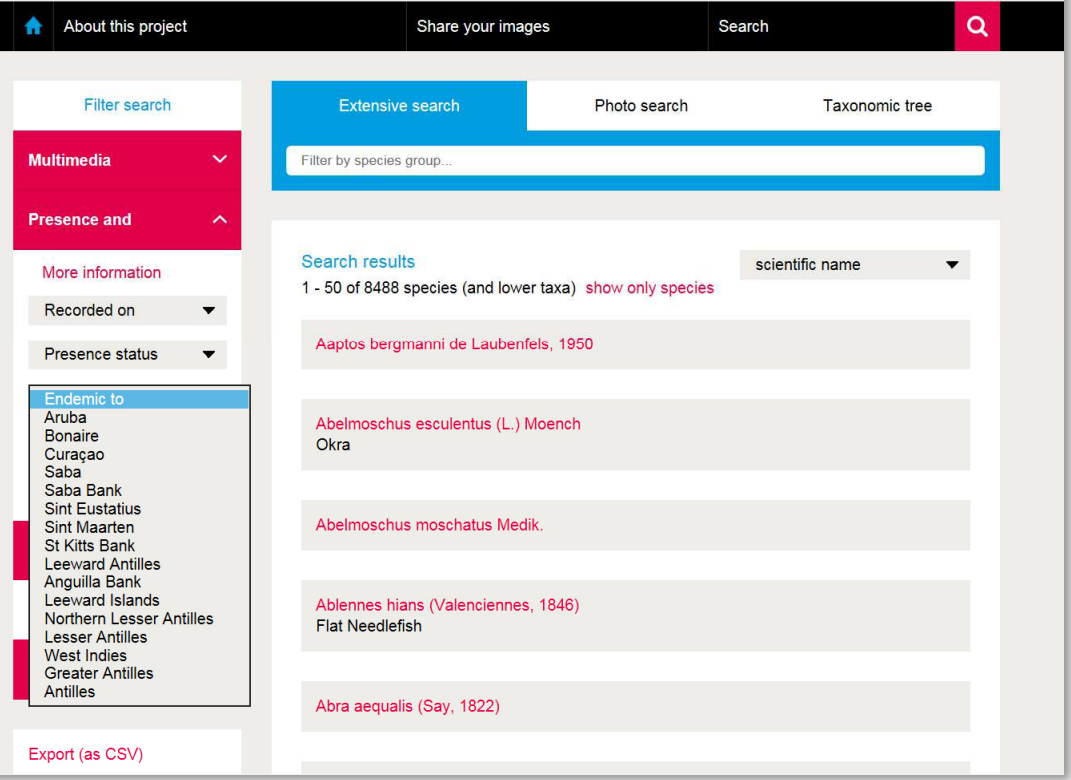

Figure 2. Dutch Caribbean Species Register (www. https://www.dutchcaribbeanspecies.org/). 


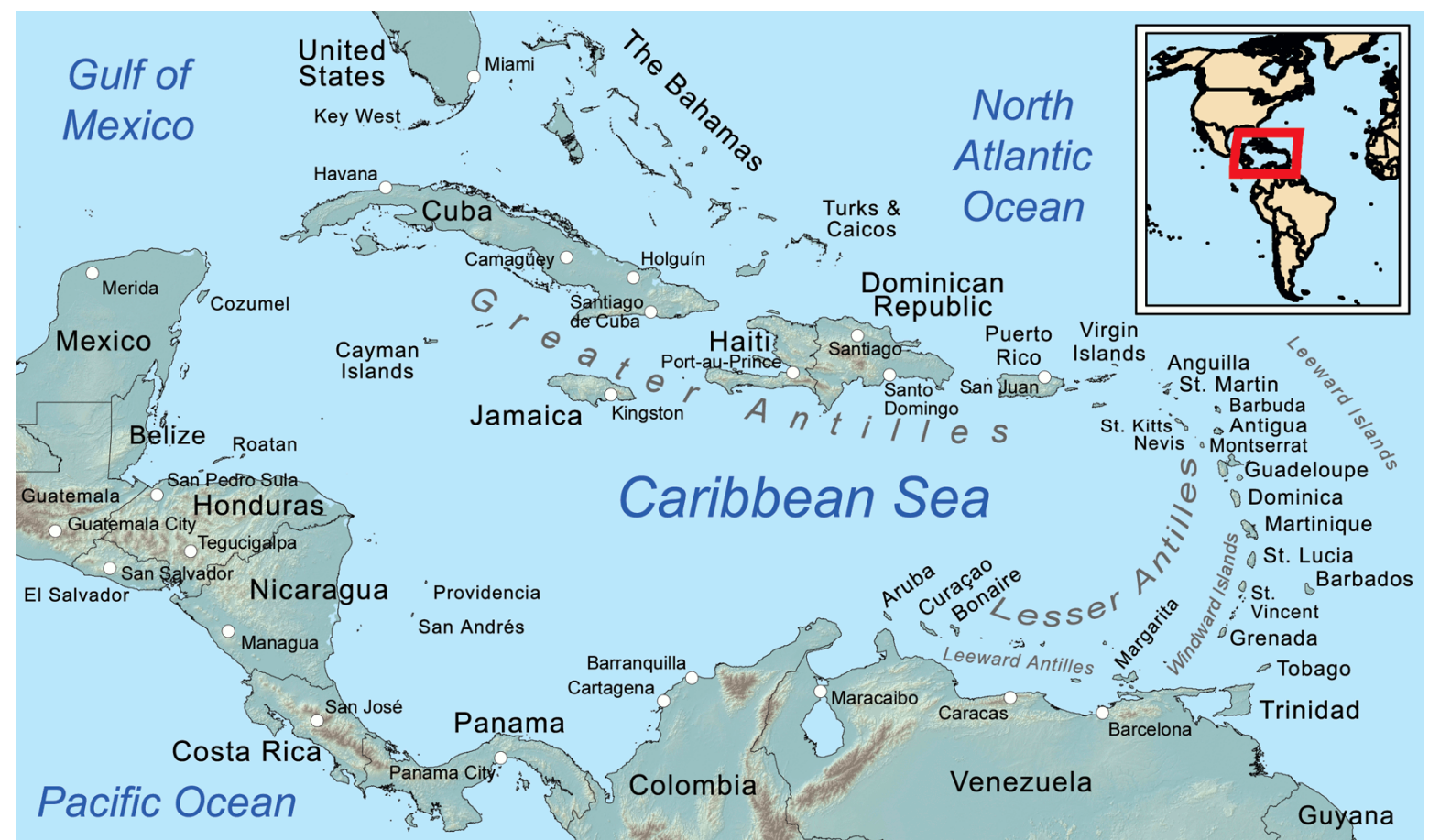

Figure 3. General map of the Caribbean Sea, showing the Greater Antilles, the Lesser Antilles, the Windward Islands, the Leeward Islands and the Leeward Antilles (source: Wikimedia,

https://upload.wikimedia.org/wikipedia/commons/9/98/Caribbean_general_map.png).

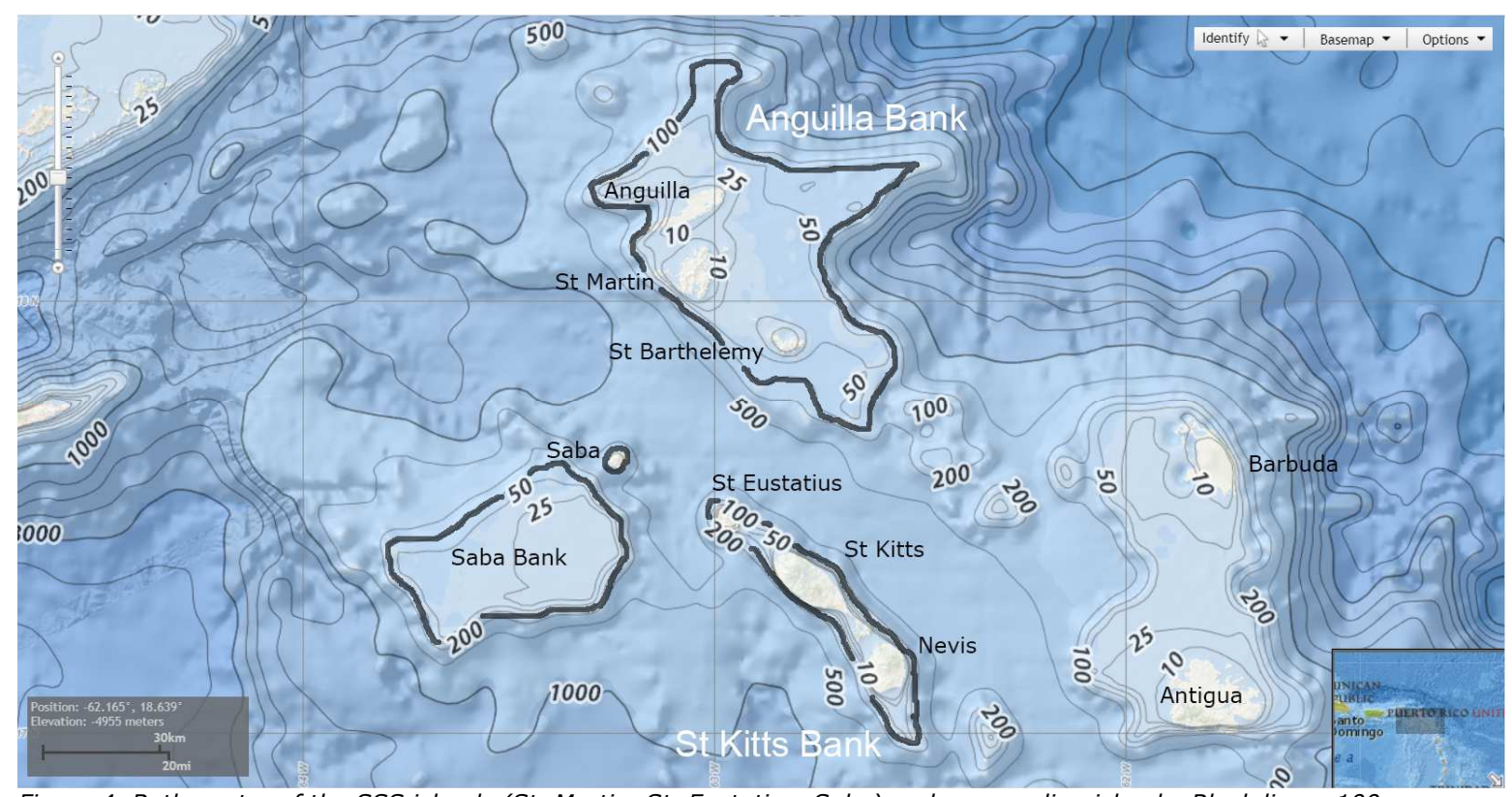

Figure 4. Bathymetry of the SSS islands (St. Martin, St. Eustatius, Saba) and surrounding islands. Black lines: $100 \mathrm{~m}$ isobath around the SSS islands and Saba Bank (adapted map from NOAA:

https://maps.ngdc.noaa.gov/viewers/bathymetry/). 


\section{Materials and Methods}

\section{$2.1 \quad$ Endemics}

\subsubsection{Definitions}

The following definitions are used in this report:

- Species: In this report, 'species' can refer to both the level of species and subspecies, to increase readability of the text. Subspecies are mainly found within butterflies, birds and molluscs (see Results).

- Island endemics: Species or subspecies that are only known to occur on one of the SSS islands (Saba, St. Eustatius or St. Martin (including the French part) or Saba Bank.

- Endemics: Species or subspecies endemic to larger geographical areas (e.g. Nothern Lesser Antilles endemics, Lesser Antilles endemics, etc.) (for geographical names, see 2.1.5).

- Potential endemics: Species or subspecies endemic to one or more of the surrounding islands (Anguilla, St. Barthélemy, St. Kitts and Nevis), not known for the SSS islands, that potentially could have counterparts on the SSS islands or Saba Bank.

\subsubsection{Identification of endemics}

The total number of (sub)species currently registered in the Dutch Caribbean Species Register at the start of the project (July 2018) was 8106 (1931 Saba, 827 Saba Bank, 2592 St. Eustatius and 2274 St. Maarten). A number of species groups were excluded from the assessment (Fungi, Chromista, Foraminifera, Bryophyta and Marchantiophyta) because no specialists were available to consult and/or it was estimated that no information on endemics could be retrieved within the time frame of the project. The reduced list of relevance therefore only contained Plantae and Animalia (plants and animal (sub)species) for the SSS Islands and Saba Bank, totalling 4107 species, with 58 listed endemics (see 1.5).

Next, the list was narrowed down to a list of 1940 (sub)species by excluding the taxa that have a wide distribution (e.g. American continent, West Indies, etc.) based on the existing distribution information in the Dutch Caribbean Species Register. Also species occurring both on the SSS and the ABC islands (for abbreviations: see 2.1.5) were removed from consideration. The remaining species list was divided among a number of taxonomy specialists to identify endemic species, based on existing literature. Available literature includes biological inventories for these islands (Rojer 1997abc), miscellaneous recent papers describing new species of insects such as butterflies (Hill, 2010), (sea)spiders and scorpions (Teruel 2008; Teruel \& Questel 2011ab), plants (Krings \& Axelrod 2013), fish (Williams et al. 2010) and corals (Etnoyer et al. 2010). 
The following species groups were reviewed (in alphabetical order):

Table 1. List of species groups and taxonomy specialists that reviewed them.

\begin{tabular}{|c|c|c|c|c|c|}
\hline Kingdom & Phylum & Group & Common name & Specialist & Affiliation \\
\hline \multirow[t]{15}{*}{ Animals } & Annelida, & Polychaeta & Bristle worms & H. ten Hove & Naturalis Biodiversity Center \\
\hline & Arthropoda & Isopoda & Isopods & R. Vonk & $\begin{array}{l}\text { Naturalis Biodiversity Center } \\
\text { (www.naturalis.nl) }\end{array}$ \\
\hline & & Araneae & Spiders, scorpions & S. Crews & $\begin{array}{l}\text { California Academy of Sciences } \\
\text { (www.calacademy.org) }\end{array}$ \\
\hline & & Decapoda & $\begin{array}{l}\text { Crabs, lobsters, } \\
\text { shrimp }\end{array}$ & C. Fransen & Naturalis Biodiversity Center \\
\hline & & $\begin{array}{l}\text { Diptera, } \\
\text { Apidae, } \\
\text { Odonata }\end{array}$ & $\begin{array}{l}\text { Flies, mosquitos, } \\
\text { bees, dragonflies, } \\
\text { etc. }\end{array}$ & J. Smit & $\begin{array}{l}\text { EIS-Knowledge Center } \\
\text { Netherlands, (www.eis- } \\
\text { nederland.nl) }\end{array}$ \\
\hline & & $\begin{array}{l}\text { Diptera, } \\
\text { Odonata }\end{array}$ & & K.-D. B. Dijkstra & Naturalis Biodiversity Center \\
\hline & Chordata & $\begin{array}{l}\text { Amphibia, } \\
\text { Reptilia }\end{array}$ & $\begin{array}{l}\text { Ampbians, } \\
\text { reptiles }\end{array}$ & G. van Buurt & $\begin{array}{l}\text { Curacao } \\
\text { (gvanbuurt@gmail.com) }\end{array}$ \\
\hline & & Aves & Birds & P. Kamminga & Naturalis Biodiversity Center \\
\hline & & Chiroptera & Bats & O. Doest & $\begin{array}{l}\text { Carmabi, Curaçao, } \\
\text { (www.carmabi.org) }\end{array}$ \\
\hline & Cnidaria & Corals & & B. Hoeksema & Naturalis Biodiversity Center \\
\hline & Mollusca & Molluscs & $\begin{array}{l}\text { Freshwater and } \\
\text { terrestrial } \\
\text { molluscs }\end{array}$ & A. Hovestadt & \\
\hline & & & $\begin{array}{l}\text { Freshwater and } \\
\text { terrestrial } \\
\text { molluscs }\end{array}$ & T. Neckheim & \\
\hline & & & $\begin{array}{l}\text { Freshwater and } \\
\text { terrestrial } \\
\text { molluscs }\end{array}$ & S. van Leeuwen & $\begin{array}{l}\text { Anemoon Foundation } \\
\text { (www.anemoon.org) }\end{array}$ \\
\hline & & & Marine molluscs & J. Goud & Naturalis Biodiversity Center \\
\hline & Porifera & Sponges & & $\begin{array}{l}\text { N. de Voogd } \\
\text { R. van Soest }\end{array}$ & Naturalis Biodiversity Center \\
\hline Plants & $\begin{array}{l}\text { Rhodophyta } \\
\text { Chlorophyta }\end{array}$ & $\begin{array}{l}\text { Red algae } \\
\text { plants, green } \\
\text { algae }\end{array}$ & & $\begin{array}{l}\text { W. Prud'homme } \\
\text { van Reine }\end{array}$ & $\begin{array}{l}\text { Naturalis Biodiversity } \\
\text { Center }\end{array}$ \\
\hline
\end{tabular}

In addition, for some species groups (e.g. Echinodermata, marine Mollusca, Lepidoptera), online databases and literature were consulted to obtain geographical distribution information (www.marinespecies.org; www.observation.org; www.inaturalist.org, Hill 2012) e.g. if no taxonomy specialists were available within the timeframe of the project.

During the literature research, 7 additional endemic species at different endemic levels were found that were not yet registered in the Dutch Caribbean Species Register in July 2018, consisting of 3 insect species: Lophoscutus geijskesi (Saba endemic: Kormilev \& Van Doesburg 1986); Alepia apexalba (Saba endemic: Wagner et al. 2010); Cyrtoxipha orientalis (Antilles endemic: Bland \& Desutter-Grandcolas 2003), 1 gastropod species: Lyria sabaensis (endemic to Saba Bank, Bail 1993) and 3 plant species: Cinnamomum falcatum (endemic to Lesser Antilles: Broome 2007); Epidendrum pallidiflorum (endemic to Lesser Antilles: Broome et al. 2007); Coccoloba $x$ boxii (' $x$ ' means nothospecies: 'hybrid which is formed by direct hybridization of two species, not other hybrids' ${ }^{\prime}$; endemic to Northern Lesser Antilles: Broome et al. 2007); The species were added to the species register by Naturalis Biodiversity Center and included in further analyses in this report.

Since we excluded species that were registered for the both ABC and SSS islands and Saba Bank, it is possible that some endemic species were removed wrongly, i.e. those endemic species from the SSS islands that have been introduced to the ABC islands. For some species, this was corrected, e.g. Agave karatto, but not all species were checked.

For many species in our list, the geographical distribution was only quickly assessed, due to time restrictions. We expect that a closer study of the species ranges may yield a narrower distribution for several listed species, thus effectively increasing the degree of endemism of many of such species.

\footnotetext{
${ }^{1}$ https://en.wiktionary.org/wiki/nothospecies
} 


\subsubsection{Identification of potential endemic species}

To identify potential endemic species, we inventoried the species lists of endemics for Anguilla, the French part of St. Martin, St. Barthélemy and St. Kitts \& Nevis from the BEST project report (BEST 2016) and other literature and databases found through a brief literature research (Table 2). Only endemics up to the level of the Lesser Antilles, and not present on the SSS islands and Saba Bank are presented. For these species, it was assessed if they could be present on the SSS islands or Saba Bank (potential endemics).

Table 2. Overview of databases and literature with information on endemics for surrounding islands and the French part of St. Maarten (i.e. St. Martin).

\begin{tabular}{ll} 
Island & Database/literatures \\
\hline Anguilla & $\begin{array}{l}\text { Proctor \& Fleming (1999). Report with species lists for } \\
\text { British overseas territories } \\
\text { BEST (2016). EU project with lists of endemics per island }\end{array}$ \\
\hline St. Martin (French part) & $\begin{array}{l}\text { INPN: Database 'Inventaire National dus Patrimoine } \\
\text { Naturelle' (https://inpn.mnhn.fr/accueil/index?lg=en) (use } \\
\text { drop down menu to select an island, then select endemic } \\
\text { species); BEST (2016) }\end{array}$ \\
\hline St. Barthélemy & INPN; BEST (2016) \\
\hline St. Kitts and Nevis & Horwirth \& Lindsay (1999) \\
\hline Database of Plants of the Eastern Caribbean & $\begin{array}{l}\text { Broome et al. (2007): Barbados Herbarium of the University } \\
\text { of the West Indies } \\
\text { (http://ecflora.cavehill.uwi.edu/advsearch.php; select } \\
\text { 'endemic' and an island name) }\end{array}$ \\
\hline
\end{tabular}




\subsubsection{New species}

A number of recent publications contain information on new species that have not yet been described (i.e. they do not have an official species name yet). Once they have officially been described, it will become clear if they are endemics. New species are therefore listed in a separate paragraph (3.5).

\subsubsection{Geographical regions}

To refer to the distribution of a species, existing geographical names for different groupings of islands were used (Figure 5) corresponding to the regions used in the Dutch Caribbean Species Register (Table 3) and complemented with some extra regions (Anguilla Bank, St. Kitts Bank, Northern and Southern Lesser Antilles, indicated with '*'). Names of regions and islands were put in a spreadsheet (Table 4) to allow for a quick assignment of species distributions found in the literature to the regions used in this report.

In this report, most endemic species of the SSS islands and Saba Bank were found to be endemic on the level of one of the SSS islands or Saba Bank ('island endemics'), Northern Lesser Antilles, Lesser Antilles and/or Greater Antilles. Species endemic to even larger regions were put in the category 'Other Regions' (e.g. West Indies or Caribbean). Since only few species were endemic to the level of the St Kitts Bank or Anguilla Bank, they were grouped with the Northern Lesser Antilles endemics.

Table 3. Geographical regions to define species distributions (source: the Dutch Caribbean Species Register with some additions from A. Debrot*). Definitions in black were used in this report to describe species distributions.

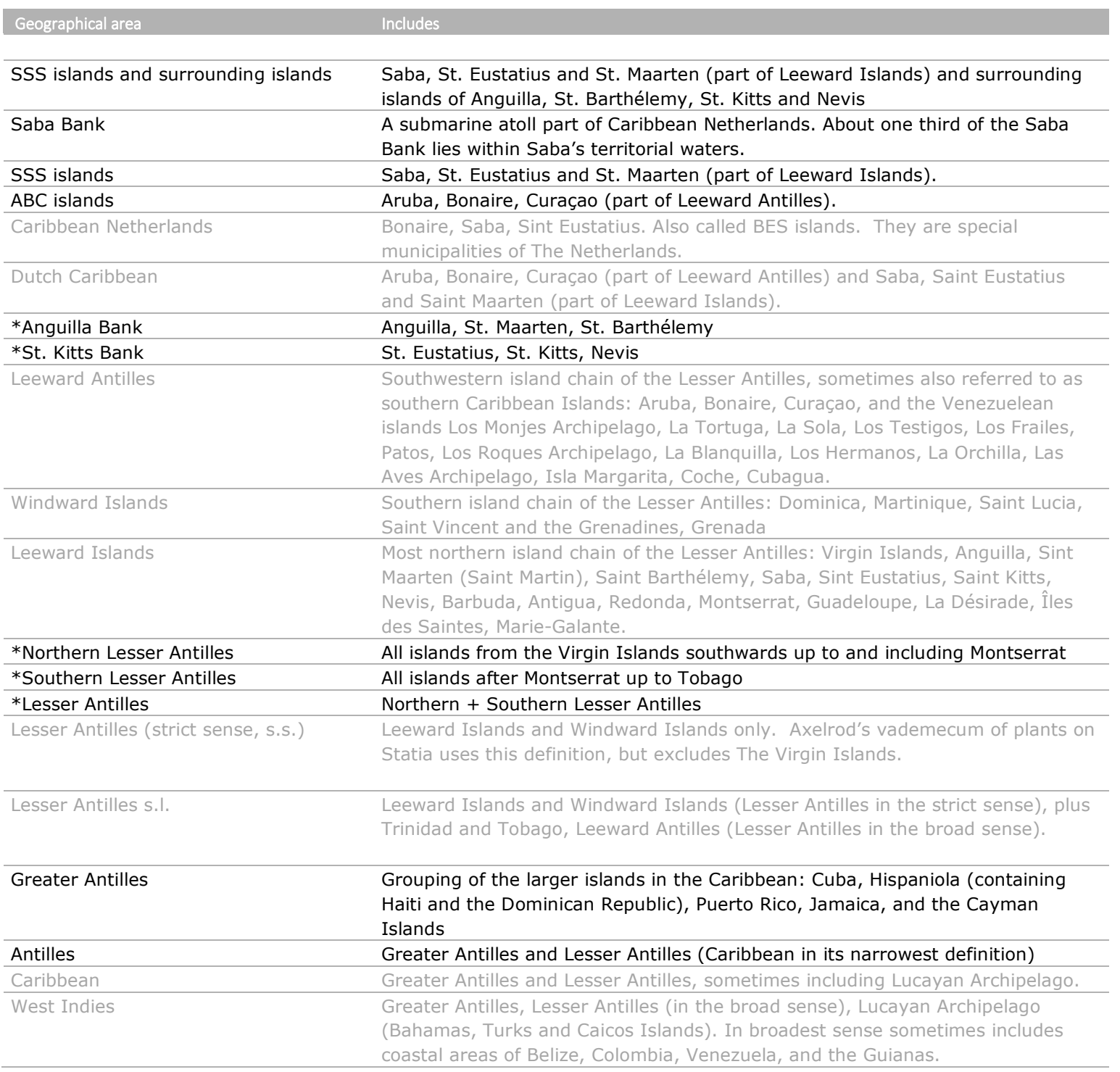


Table 4. Geographical regions (columns) and islands (rows).

\begin{tabular}{|c|c|c|c|c|c|c|c|c|c|c|c|c|c|c|c|c|c|}
\hline Island & 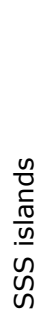 & 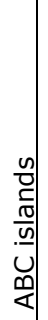 & 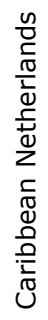 & 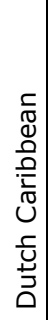 & 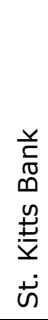 & 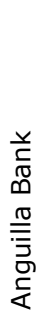 & 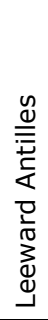 & 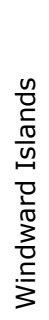 & 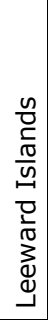 & 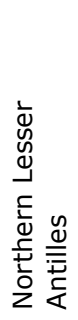 & 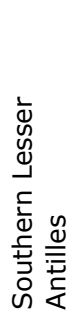 & 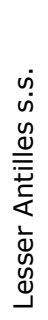 & 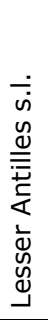 & 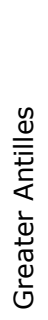 & 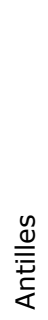 & 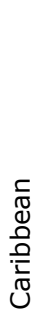 & 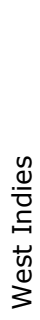 \\
\hline Saba & 1 & 0 & 1 & 1 & 0 & 0 & 0 & 0 & 1 & 1 & 0 & 1 & 1 & 0 & 1 & 1 & 1 \\
\hline Saba Bank & 0 & 0 & 0 & 0 & 0 & 0 & 0 & 0 & 0 & 0 & 0 & 0 & 0 & 0 & 0 & 0 & 0 \\
\hline St. Eustatius & 1 & 0 & 1 & 1 & 1 & 0 & 0 & 0 & 1 & 1 & 0 & 1 & 1 & 0 & 1 & 1 & 1 \\
\hline St. Martin & 1 & 0 & 0 & 1 & 0 & 1 & 0 & 0 & 1 & 1 & 0 & 1 & 1 & 0 & 1 & 1 & 1 \\
\hline Aruba & 0 & 1 & 0 & 1 & 0 & 0 & 1 & 0 & 0 & 0 & 0 & 0 & 0 & 0 & 0 & 0 & 0 \\
\hline Curaçao & 0 & 1 & 0 & 1 & 0 & 0 & 1 & 0 & 0 & 0 & 0 & 0 & 0 & 0 & 0 & 0 & 0 \\
\hline Bonaire & 0 & 1 & 1 & 1 & 0 & 0 & 1 & 0 & 0 & 0 & 0 & 0 & 0 & 0 & 0 & 0 & 0 \\
\hline Virgin Islands & 0 & 0 & 0 & 0 & 0 & 0 & 0 & 0 & 1 & 1 & 0 & 0 & 1 & 0 & 1 & 1 & 1 \\
\hline Anguilla & 0 & 0 & 0 & 0 & 0 & 1 & 0 & 0 & 1 & 1 & 0 & 1 & 1 & 0 & 1 & 1 & 1 \\
\hline $\begin{array}{l}\text { Saint Barthélemy } \\
\text { (St. Barths) }\end{array}$ & 0 & 0 & 0 & 0 & 0 & 1 & 0 & 0 & 1 & 1 & 0 & 1 & 1 & 0 & 1 & 1 & 1 \\
\hline Saint Kitts & 0 & 0 & 0 & 0 & 1 & 0 & 0 & 0 & 1 & 1 & 0 & 1 & 1 & 0 & 1 & 1 & 1 \\
\hline Nevis & 0 & 0 & 0 & 0 & 1 & 0 & 0 & 0 & 1 & 1 & 0 & 1 & 1 & 0 & 1 & 1 & 1 \\
\hline Barbuda & 0 & 0 & 0 & 0 & 0 & 0 & 0 & 0 & 1 & 1 & 0 & 1 & 1 & 0 & 1 & 1 & 1 \\
\hline Antigua & 0 & 0 & 0 & 0 & 0 & 0 & 0 & 0 & 1 & 1 & 0 & 1 & 1 & 0 & 1 & 1 & 1 \\
\hline Redonda & 0 & 0 & 0 & 0 & 0 & 0 & 0 & 0 & 1 & 1 & 0 & 1 & 1 & 0 & 1 & 1 & 1 \\
\hline Montserrat & 0 & 0 & 0 & 0 & 0 & 0 & 0 & 0 & 1 & 1 & 0 & 1 & 1 & 0 & 1 & 1 & 1 \\
\hline Guadeloupe & 0 & 0 & 0 & 0 & 0 & 0 & 0 & 0 & 1 & 0 & 1 & 1 & 1 & 0 & 1 & 1 & 1 \\
\hline La Désirade & 0 & 0 & 0 & 0 & 0 & 0 & 0 & 0 & 1 & 0 & 1 & 1 & 1 & 0 & 1 & 1 & 1 \\
\hline Îles des Saintes & 0 & 0 & 0 & 0 & 0 & 0 & 0 & 0 & 1 & 0 & 1 & 1 & 1 & 0 & 1 & 1 & 1 \\
\hline Marie-Galante & 0 & 0 & 0 & 0 & 0 & 0 & 0 & 0 & 1 & 0 & 1 & 1 & 1 & 0 & 1 & 1 & 1 \\
\hline Dominica & 0 & 0 & 0 & 0 & 0 & 0 & 0 & 1 & 0 & 0 & 1 & 1 & 1 & 0 & 1 & 1 & 1 \\
\hline Martinique & 0 & 0 & 0 & 0 & 0 & 0 & 0 & 1 & 0 & 0 & 1 & 1 & 1 & 0 & 1 & 1 & 1 \\
\hline Saint Lucia & 0 & 0 & 0 & 0 & 0 & 0 & 0 & 1 & 0 & 0 & 1 & 1 & 1 & 0 & 1 & 1 & 1 \\
\hline $\begin{array}{l}\text { Saint Vincent and } \\
\text { the Grenadines }\end{array}$ & 0 & 0 & 0 & 0 & 0 & 0 & 0 & 1 & 0 & 0 & 1 & 1 & 1 & 0 & 1 & 1 & 1 \\
\hline Grenada & 0 & 0 & 0 & 0 & 0 & 0 & 0 & 1 & 0 & 0 & 1 & 1 & 1 & 0 & 1 & 1 & 1 \\
\hline Barbados & 0 & 0 & 0 & 0 & 0 & 0 & 0 & 0 & 0 & 0 & 1 & 0 & 1 & 0 & 1 & 1 & 1 \\
\hline Tobago & 0 & 0 & 0 & 0 & 0 & 0 & 0 & 0 & 0 & 0 & 1 & 0 & 1 & 0 & 1 & 1 & 1 \\
\hline Trinidad & 0 & 0 & 0 & 0 & 0 & 0 & 0 & 0 & 0 & 0 & 0 & 0 & 1 & 0 & 1 & 1 & 1 \\
\hline $\begin{array}{l}\text { Los Monjes } \\
\text { Archipelago }\end{array}$ & 0 & 0 & 0 & 0 & 0 & 0 & 1 & 0 & 0 & 0 & 0 & 0 & 1 & 0 & 1 & 1 & 1 \\
\hline La Tortuga & 0 & 0 & 0 & 0 & 0 & 0 & 1 & 0 & 0 & 0 & 0 & 0 & 1 & 0 & 1 & 1 & 1 \\
\hline La Sola & 0 & 0 & 0 & 0 & 0 & 0 & 1 & 0 & 0 & 0 & 0 & 0 & 1 & 0 & 1 & 1 & 1 \\
\hline Los Frailes & 0 & 0 & 0 & 0 & 0 & 0 & 1 & 0 & 0 & 0 & 0 & 0 & 1 & 0 & 1 & 1 & 1 \\
\hline Patos & 0 & 0 & 0 & 0 & 0 & 0 & 1 & 0 & 0 & 0 & 0 & 0 & 1 & 0 & 1 & 1 & 1 \\
\hline $\begin{array}{l}\text { los Roques } \\
\text { Archipelago }\end{array}$ & 0 & 0 & 0 & 0 & 0 & 0 & 1 & 0 & 0 & 0 & 0 & 0 & 1 & 0 & 1 & 1 & 1 \\
\hline La Blanquilla & 0 & 0 & 0 & 0 & 0 & 0 & 1 & 0 & 0 & 0 & 0 & 0 & 1 & 0 & 1 & 1 & 1 \\
\hline Los Hermanos & 0 & 0 & 0 & 0 & 0 & 0 & 1 & 0 & 0 & 0 & 0 & 0 & 1 & 0 & 1 & 1 & 1 \\
\hline La Orchila & 0 & 0 & 0 & 0 & 0 & 0 & 1 & 0 & 0 & 0 & 0 & 0 & 1 & 0 & 1 & 1 & 1 \\
\hline $\begin{array}{l}\text { Las Aves } \\
\text { Archipelago }\end{array}$ & 0 & 0 & 0 & 0 & 0 & 0 & 1 & 0 & 0 & 0 & 0 & 0 & 1 & 0 & 1 & 1 & 1 \\
\hline Isla Margarita & 0 & 0 & 0 & 0 & 0 & 0 & 1 & 0 & 0 & 0 & 0 & 0 & 1 & 0 & 1 & 1 & 1 \\
\hline Coche & 0 & 0 & 0 & 0 & 0 & 0 & 1 & 0 & 0 & 0 & 0 & 0 & 1 & 0 & 1 & 1 & 1 \\
\hline Cubaqua & 0 & 0 & 0 & 0 & 0 & 0 & 1 & 0 & 0 & 0 & 0 & 0 & 1 & 0 & 1 & 1 & 1 \\
\hline Cuba & 0 & 0 & 0 & 0 & 0 & 0 & 0 & 0 & 0 & 0 & 0 & 0 & 0 & 1 & 1 & 1 & 1 \\
\hline $\begin{array}{l}\text { Hispaniola (Haiti, } \\
\text { Dominican } \\
\text { Republic) }\end{array}$ & 0 & 0 & 0 & 0 & 0 & 0 & 0 & 0 & 0 & 0 & 0 & 0 & 0 & 1 & 1 & 1 & 1 \\
\hline Puerto Rico & 0 & 0 & 0 & 0 & 0 & 0 & 0 & 0 & 0 & 0 & 0 & 0 & 0 & 1 & 1 & 1 & 1 \\
\hline Jamaica & 0 & 0 & 0 & 0 & 0 & 0 & 0 & 0 & 0 & 0 & 0 & 0 & 0 & 1 & 1 & 1 & 1 \\
\hline Cayman Islands & 0 & 0 & 0 & 0 & 0 & 0 & 0 & 0 & 0 & 0 & 0 & 0 & 0 & 1 & 1 & 1 & 1 \\
\hline $\begin{array}{l}\text { Lucayan } \\
\text { Archipelago } \\
\text { (Bahamas, Turks } \\
\text { and Caicos } \\
\text { Islands) }\end{array}$ & & & & & & & & & & & & & & & & & \\
\hline Islands) & 0 & 0 & 0 & 0 & 0 & 0 & 0 & 0 & 0 & 0 & 0 & 0 & 0 & 0 & 0 & 0 & 1 \\
\hline
\end{tabular}



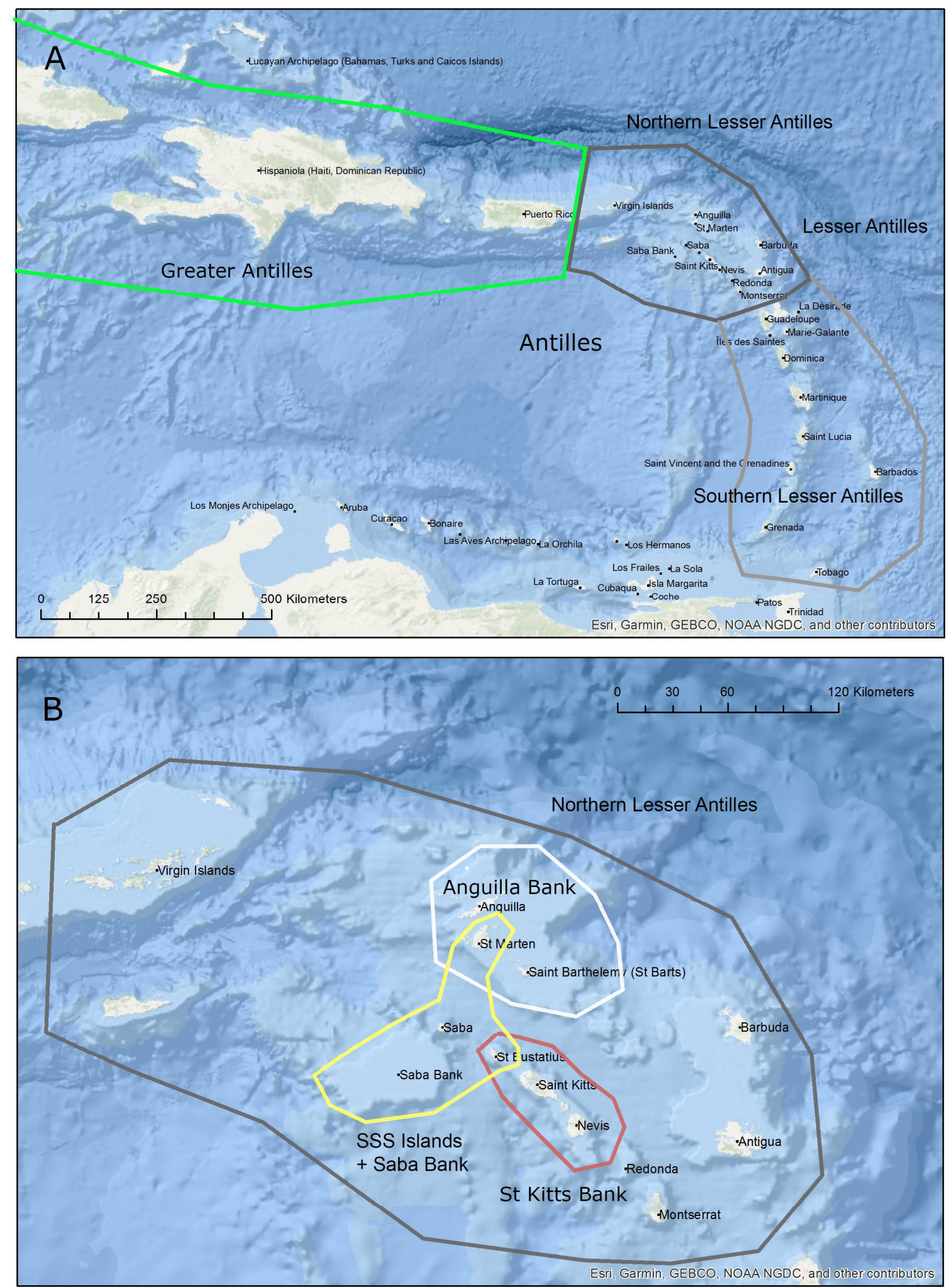

Figure 5. Schematic representation of geographical areas referred to in this report: A) Northern and Southern Lesser Antilles (dark and light grey), together referred to as the Lesser Antilles, and Greater Antilles (green). The Lesser Antilles and Greater Antilles together are referred to as the Antilles. B) Northern Lesser Antilles (grey line), SSS Islands and Saba Bank (yellow), St. Kitts Bank (red) and Anguilla Bank (white). 


\subsubsection{Additional sources of information}

Databases and checklists additional to the Species Register that were used to check for endemics:

- Plants of the Eastern Caribbean (select 'endemic' and an island name)

http://ecflora.cavehill.uwi.edu/advsearch.php

- Living National Treasures:

- http://Intreasures.com/saba.html (Saba)

- http://Intreasures.com/se.html (St. Eustatius) 


\subsection{Conservation Status}

The IUCN Red List conservation status was extracted from the IUCN database and follows the IUCN criteria (IUCN, 2012) (Table 5). For the Chondrichtyes (sharks, rays) a regional IUCN assessment has been made (Kyne et al. 2012), while for the other species only world-wide assessments are available (http://www.iucnredlist.org/). The IUCN conservation status for species occurring in the Dutch Caribbean have been published in http://www.dcnanature.org/wp-content/uploads/2013/01/3-RedList.pdf. Note that not all species have been assessed by IUCN, and that only endemic species have been assessed in this report.

Table 5. IUCN conservation status descriptions (IUCN, 2012).

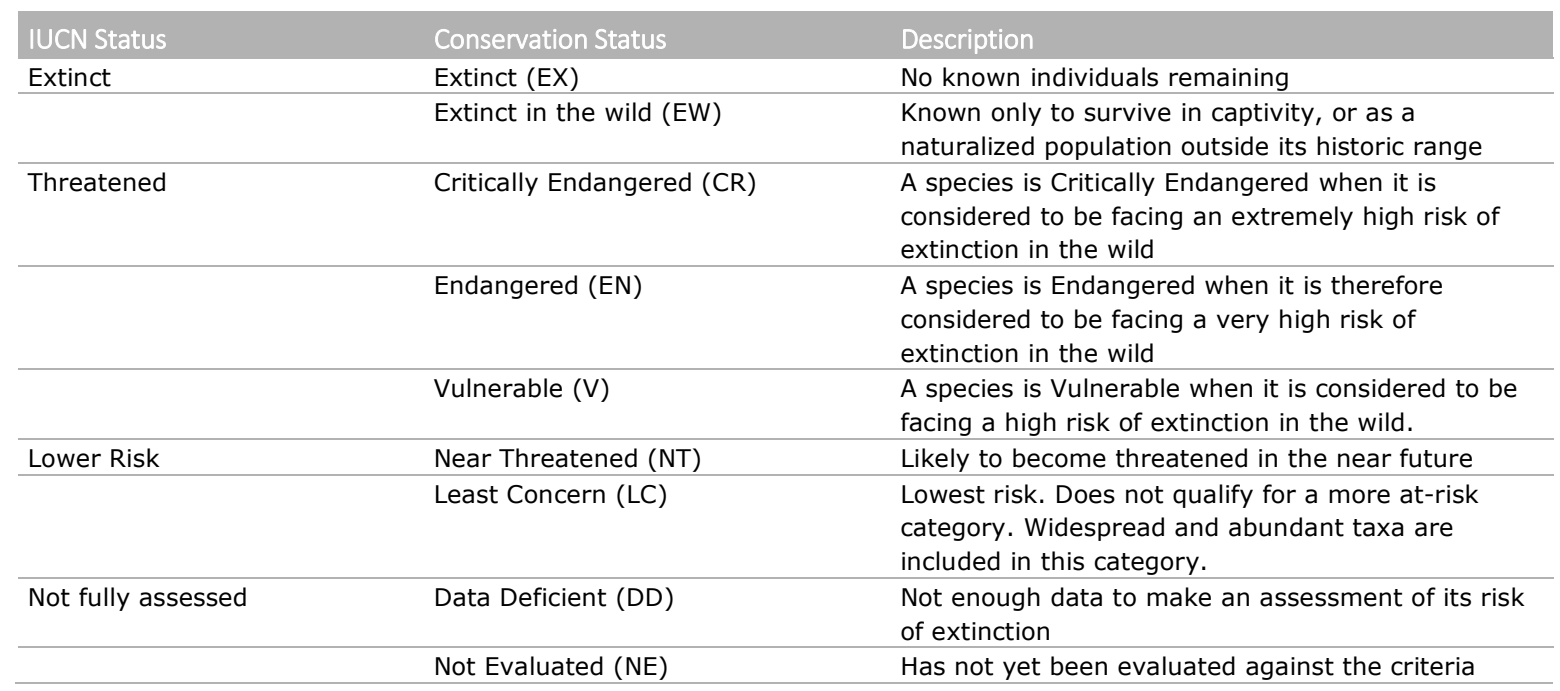




\section{Results}

\subsection{Total number of endemic taxa for the SSS islands and the Saba Bank}

In Annexes 1 and 2, an overview is given of the total number of species, and the number of endemic species per species group for the SSS islands and Saba Bank, with the level of endemism. In total, 4114 animal and plant (sub)species are registered for the SSS islands and Saba Bank (registered (sub)species per July 2018, plus additional (sub)species found in this report). After analyses of the (sub)species groups by specialists and through literature research, and by excluding the 2060 taxa that also occur at the ABC islands, and by including the 7 endemics found in various reports and lists during this research (see paragraph 2.1.2), a total number of 222 (sub)species (197 animal and 25 plant species) were found to be endemic (5\%) with $35(0.8 \%)$ (sub)species being endemic to only one of the SSS islands or Saba Bank (island endemics).

\subsection{Species and subspecies}

In Table 6 the number of species and subspecies are shown. In total, the 222 endemic taxa (all geographical levels) consist of 32 subspecies and 190 species. Most endemic subspecies are found within birds (Aves: 16), butterflies and moths (Lepidoptera: 6), gastropods (5) and bats (3). Also 1 beetle (Coleoptera) and 1 taxon beloning to the Orthoptera are endemic subspecies. At the level of the SSS islands and Saba Bank, no subspecies are found, only species.

Table 6. Numbers of endemic species and subspecies per taxonomic level.

\begin{tabular}{|c|c|c|c|c|}
\hline Taxa & $\begin{array}{r}\text { All endemic levels } \\
\text { Subspecies }\end{array}$ & Species & Grand Total & $\begin{array}{l}\text { SSS islands and Saba Bank } \\
\text { Species }\end{array}$ \\
\hline Animalia & 32 & 165 & 198 & 31 \\
\hline Annelida & & 1 & 1 & 1 \\
\hline Polychaeta & & 1 & 1 & 1 \\
\hline Phyllodocida & & 1 & 1 & 1 \\
\hline Arthropoda & 8 & 100 & 108 & 21 \\
\hline Arachnida & & 23 & 23 & 4 \\
\hline Hexanauplia & & 2 & 2 & 2 \\
\hline Insecta & 8 & 70 & 78 & 15 \\
\hline Coleoptera & 1 & 32 & 33 & 3 \\
\hline Diptera & & 4 & 4 & 1 \\
\hline Hemiptera & & 3 & 3 & 1 \\
\hline Hymenoptera & & 3 & 3 & - \\
\hline Lepidoptera & 6 & 6 & 12 & - \\
\hline Odonata & & 1 & 1 & - \\
\hline Orthoptera & 1 & 21 & 22 & 10 \\
\hline Malacostraca & & 4 & 4 & - \\
\hline Pycnogonida & & 1 & 1 & - \\
\hline Chordata & 19 & 31 & 50 & 5 \\
\hline Actinopterygii & & 4 & 4 & 2 \\
\hline Amphibia & & 1 & 1 & - \\
\hline Aves & 16 & 7 & 23 & - \\
\hline Chondrichthyes & & 1 & 1 & - \\
\hline Mammalia (bats) & 3 & 2 & 5 & - \\
\hline Reptilia & & 16 & 16 & 3 \\
\hline Cnidaria & & 5 & 5 & - \\
\hline Anthozoa & & 4 & 4 & - \\
\hline Hydrozoa & & 1 & 1 & - \\
\hline Mollusca & 5 & 28 & 33 & 4 \\
\hline Bivalvia & & 5 & 5 & 1 \\
\hline Gastropoda & 5 & 23 & 28 & 3 \\
\hline Platyhelminthes & & 1 & 1 & - \\
\hline Plantae & & 25 & 25 & 4 \\
\hline Rhodophyta & & 3 & 3 & 1 \\
\hline Tracheophyta & & 22 & 22 & 3 \\
\hline Grand Total & 32 & 190 & 223 & 35 \\
\hline
\end{tabular}




\subsection{Marine versus terrestrial endemic taxa}

Of the total number of 4114 registered animal and plant species (see Table 7), 1858 species are strictly related to marine habitats (sum of 'marine' animals and plant species, 1623+262), 1978 to terrestrial habitats, 43 to freshwater habitats and 3 to brackish habitats, with 207 species using multiple habitats (see combinations of habitats in Table 7).

Of the 223 endemic species (all geographical levels), 32 are strictly related to marine habitats, 162 to terrestrial, 1 to freshwater and none to brackish habitats, with 5 species using two or three habitats (Table 7). Of the 25 endemic plant species, 3 are marine (red algae) and 22 terrestrial (vascular plants). Note that a number of groups that probably also contains endemics, including e.g. brown algae (Chromista) were not analysed in this report.

Within the 35 island endemics of the SSS islands and Saba Bank, 26 are related to terrestrial habitats and 8 to marine habitats (Table 7).

The percentage of strictly marine endemics compared to the total number of marine species $(32 / 1858=2 \%)$ is comparable to the percentage of freshwater endemics $(1 / 43=2 \%)$, but lower than the percentage of terrestrial endemics $(162 / 1978=8 \%)$.

Table 7. Endemic taxa per habitat.

\begin{tabular}{|c|c|c|c|}
\hline Habitat & Total $\mathbf{N}$ species & $\begin{array}{l}\text { N endemic } \\
\text { taxa (all } \\
\text { levels) }\end{array}$ & $\begin{array}{l}\mathbf{N} \text { island } \\
\text { endemics } \\
\text { (SsS } \\
\text { islands or } \\
\text { Saba Bank) }\end{array}$ \\
\hline Animalia & 2661 & 198 & 31 \\
\hline Brackish water & 1 & - & - \\
\hline Brackish water, Marine & 2 & 1 & 1 \\
\hline Freshwater, Brackish water, Marine & 10 & - & - \\
\hline Freshwater|Brackish water & 1 & - & - \\
\hline Marine & 1623 & 31 & 7 \\
\hline Terrestrial & 797 & 161 & 23 \\
\hline Terrestrial, Brackish water, Marine & 6 & - & - \\
\hline Terrestrial, Freshwater & 66 & 3 & - \\
\hline Terrestrial|Freshwater|Marine & 1 & - & - \\
\hline Plantae & 1453 & 25 & 4 \\
\hline Brackish water, Marine & 2 & - & - \\
\hline Freshwater & 2 & - & - \\
\hline Marine & 262 & 1 & 1 \\
\hline Terrestrial & 1181 & 1 & 3 \\
\hline Terrestrial, Brackish water, Marine & 1 & - & - \\
\hline Terrestrial, Freshwater & 2 & - & - \\
\hline Terrestrial, Freshwater, Brackish water & 1 & - & - \\
\hline Terrestrial, Marine & 2 & - & - \\
\hline Grand Total & 4114 & 223 & 35 \\
\hline
\end{tabular}




\subsection{Endemics of the SSS islands and Saba Bank}

The total list of endemics can be found in Annex 2. Here we only show the island endemics per island and for the Saba Bank. The number of island endemics are:

- St. Martin: 12 island endemics (10 animal species and 2 plant species) (Table 8)

- St. Eustatius: 10 island endemics: (8 animals species and 2 plant species) (Table 9).

- Saba: 10 island endemics: (10 animals species, 0 plant species) (Table 10).

- Saba Bank: 3 endemics (3 animal species, 0 plant species) (Table 11)

Table 8. Island endemics registered for St. Martin (taxa endemic on larger scales such as Lesser Antilles are not included).

\begin{tabular}{|c|c|c|}
\hline St. Martin & $\begin{array}{l}\text { Common } \\
\text { name }\end{array}$ & Total \\
\hline Animalia & & 10 \\
\hline \multicolumn{3}{|l|}{ Arthropoda } \\
\hline \multicolumn{3}{|l|}{ Arachnida } \\
\hline 1. Amblyolpium martinensis Van den Tooren, 2002 & - & \\
\hline \multicolumn{3}{|l|}{ Hexanauplia } \\
\hline 2. Acanthomolgus seticornis Stock, 1975 & - & \\
\hline 3. Leptocaris glaber Fiers, 1986 & - & \\
\hline \multicolumn{3}{|l|}{ Insecta } \\
\hline 4. Phoebolampta caeruleotergum Heads, 2008 & $\begin{array}{l}\text { Leaf Mimic } \\
\text { Katydid }\end{array}$ & \\
\hline 5. Phyllophaga stehlei Chalumeau, 1985 & - & \\
\hline 6. Solenoptera chalumeaui Villiers, 1979 & $\begin{array}{l}\text { Michelle's } \\
\text { Metallic } \\
\text { Longhorn }\end{array}$ & \\
\hline \multicolumn{3}{|l|}{ Chordata } \\
\hline \multicolumn{3}{|l|}{ Actinopterygii } \\
\hline 7. Melanorhinus boekei & $\begin{array}{l}\text { St. Maarten } \\
\text { Pejerry }\end{array}$ & \\
\hline \multicolumn{3}{|l|}{ Reptilia } \\
\hline 8. Spondylurus martinae Hedges \& Conn, 2012 & Slipperyback & \\
\hline 9. Thecadactylus oskrobapreinorum Köhler \& Vesely, 2011 & $\begin{array}{l}\text { St. Maarten } \\
\text { Thick-tailed } \\
\text { Gecko }\end{array}$ & \\
\hline
\end{tabular}

\begin{tabular}{|c|c|c|}
\hline \multirow{2}{*}{\multicolumn{3}{|c|}{ Mollusca }} \\
\hline & & \\
\hline \multicolumn{3}{|l|}{ Gastropoda } \\
\hline 10. Conasprella berschaueri (Petuch \& Myers, 2014) & - & \\
\hline Plantae & & 2 \\
\hline \multicolumn{3}{|l|}{ Tracheophyta } \\
\hline \multicolumn{3}{|l|}{ Spermatopsida } \\
\hline 11. Calyptranthes boldinghii Urb. & - & \\
\hline 12. Galactia nummularia Urb. & - & \\
\hline Grand Total & & 12 \\
\hline
\end{tabular}


Table 9. Island endemics registered for St. Eustatius (taxa endemic on larger scales such as Lesser Antilles are not included).

\begin{tabular}{|c|c|c|}
\hline St. Eustatius & $\begin{array}{l}\text { Common } \\
\text { name }\end{array}$ & total \\
\hline Animalia & & 8 \\
\hline \multicolumn{3}{|l|}{ Annelida } \\
\hline \multicolumn{3}{|l|}{ Polychaeta } \\
\hline 1. Namanereis sublittoralis Glasby, 1999 & - & \\
\hline \multicolumn{3}{|l|}{ Arthropoda } \\
\hline \multicolumn{3}{|l|}{ Arachnida } \\
\hline 2. Pachyolpium confusum Van den Tooren, 2002 & - & \\
\hline \multicolumn{3}{|l|}{ Insecta } \\
\hline 3. Lactista eustatia Bland, 2002 & - & \\
\hline 4. Laurepa maculata (Desutter-Grandcolas \& Bland, 2003) & - & \\
\hline 5. Orocharis angustus Desutter-Grandcolas, 2003 & - & \\
\hline 6. Orocharis minutus Desutter-Grandcolas, 2003 & - & \\
\hline 7. Cyrtoxipha orientalis (Bland \& Desutter-Grandcolas, 2003) & - & \\
\hline \multicolumn{3}{|l|}{ Mollusca } \\
\hline \multicolumn{3}{|l|}{ Gastropoda } \\
\hline 8. Glyphyalus quillensis de Winter, van Leeuwen \& Hovestadt, 2016 & - & \\
\hline
\end{tabular}

\section{Plantae}

\section{Rhodophyta}

Florideophyceae

9. Stichothamnion antillarum Vroman

\section{Tracheophyta}

Spermatopsida

10. Gonolobus aloiensis Krings \& F.S.Axelrod 
Table 10. Island endemics registered for Saba (taxa endemic on larger scales such as Lesser Antilles are not included).

\begin{tabular}{|c|c|c|}
\hline SABA & $\begin{array}{l}\text { Common } \\
\text { name }\end{array}$ & Total \\
\hline Animalia & & 10 \\
\hline \multicolumn{3}{|l|}{ Arthropoda } \\
\hline \multicolumn{3}{|l|}{ Arachnida } \\
\hline 1. Corticochernes sabae Van den Tooren, 2008 & - & \\
\hline 2. Stenoonops saba Platnich \& Dupérré, 2010 & - & \\
\hline \multicolumn{3}{|l|}{ Insecta } \\
\hline 3. Alepia apexalba Wagner, Richardson \& Richardson, 2010 & - & \\
\hline 4. Antillicharis naskreckii Otte \& Perez-Gelabert, 2009 & - & \\
\hline 5. Antillicharis sabaensis Otte \& Perez-Gelabert, 2009 & - & \\
\hline 6. Chrysobothris sabae Maier \& Ivie, 2013 & - & \\
\hline 7. Laurellia saba Otte \& Perez-Gelabert, 2009 & - & \\
\hline 8. Laurepa saba Otte \& Perez-Gelabert, 2009 & - & \\
\hline 9. Lophoscutus geijskesi Kormilev \& Van Doesburg, 1986 & - & \\
\hline \multicolumn{3}{|l|}{ Chordata } \\
\hline \multicolumn{3}{|l|}{ Reptilia } \\
\hline 10. Anolis sabanus Garman, 1887 & Saban anole & \\
\hline
\end{tabular}

Table 11. Island endemics registered for Saba Bank (taxa endemic on larger scales such as Lesser Antilles are not included).

\begin{tabular}{|c|c|c|}
\hline Saba Bank & Common name & Total \\
\hline Animalia & & 3 \\
\hline \multicolumn{3}{|l|}{ Chordata } \\
\hline \multicolumn{3}{|l|}{ Actinopterygii } \\
\hline 1. Starksia williamsi Baldwin \& Castillo, 2011 & William's blenny & \\
\hline \multicolumn{3}{|l|}{ Mollusca } \\
\hline \multicolumn{3}{|l|}{ Bivalvia } \\
\hline 2. Cardiomya saba Knudsen, 1982 & - & \\
\hline \multicolumn{3}{|l|}{ Gastropoda } \\
\hline 3. Lyria sabaensis Bail, 1993 & - & \\
\hline Grand Total & & 3 \\
\hline
\end{tabular}




\subsection{New species for the SSS islands and Saba Bank}

In recent years, a number of new species have been found on the SSS islands and Saba Bank. These species could potentially be endemic, since they have not been registered or described anywhere else before. In this paragraph we list new species that have no official scientific names yet, and that are therefore not yet registered in the Dutch Caribbean Species Register.

\subsubsection{Fish}

Williams et al. (2010), who conducted fish survey on Saba Bank, found at least 6 new species which had not yet been described Figure 6, Figure 7). We have not checked whether they are described now. Williams et al. (2010) report 270 different fish species and estimate that a total of $320-411$ species should be present on the basis of species-area curves. The species register currently contains 290 fish species for Saba Bank.

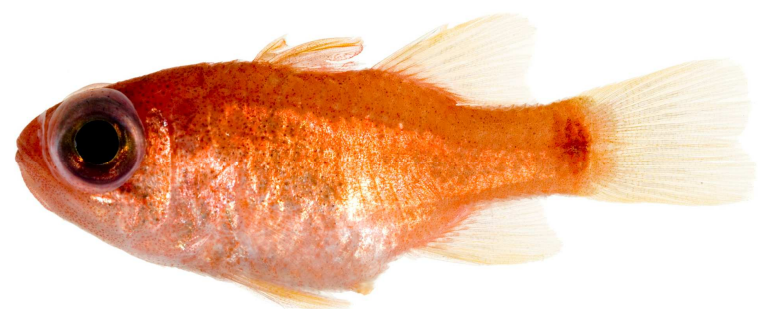

Figure 6. A new undescribed cardinalfish of Saba Bank, Apogon cf quadrisquamatus (photo: JT Williams, Williams et al., 2010).

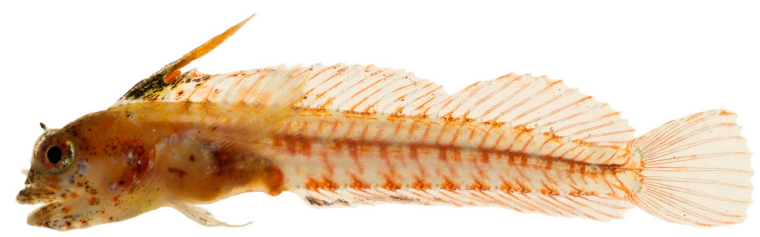

Figure 7. A new undescribed tube blenny of Saba Bank, Emblemariopsis of signifer (photo: JT Williams, Williams et al., 2010).

\subsubsection{Corals}

Two likely undescribed species of octocorals (genera Pterogorgia (Figure 8) and Lytreia) were found by Etnoyer et al. (2010) during a rapid assessment of octocoral diversity and habitat on Saba Bank.

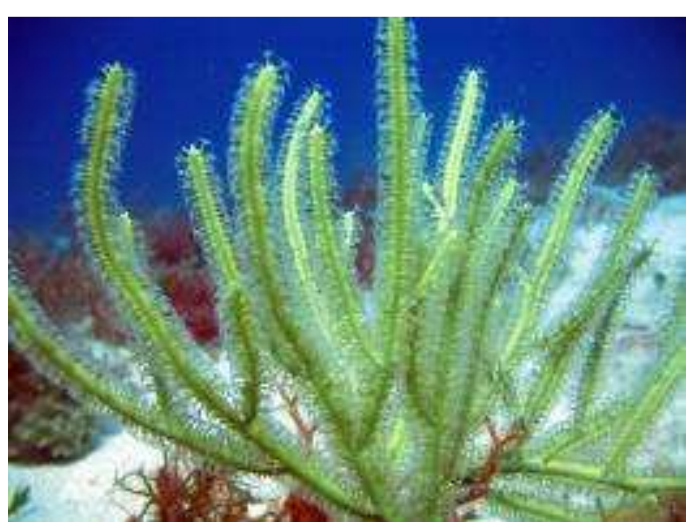

Figure 8. A new undescribed gorgonian soft coral (photo: J. Sanchez, Universidad de los Andes, Colombia). 


\subsubsection{Sponges}

On the Saba Bank, one or two new sponge species were discovered during the Saba Bank Expedition 2015 (Figure 9). These species remain to be reported and described (Wilting et al. in prep).

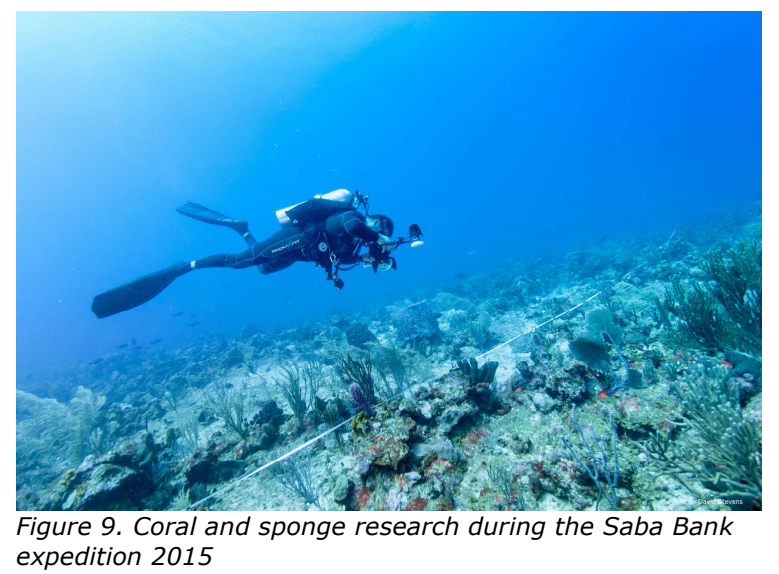

\subsection{Endemic species on neighbouring islands}

After checking lists of endemics for neighbouring islands (Anguilla, Anguilla Bank, St. Barthélemy, St. Kitts, Nevis, St. Kitts Bank and the Lesser Antilles), 47 endemic species were identified that are not present on the SSS islands and Saba Bank (Table 12). In the French database for St. Martin, no additional species were found compared to the species present in the Species Register. The endemics of the neighbouring islands include a number of Arachnida (spiders and scorpions), beetles, a cockroach, ground lizards and blind snakes, ferns, an orchid and some other vascular plants. The flora in St. Kitts and Nevis has been well studied (Horwirth \& Lindsay 1999), hence the relatively large number of endemic species from St. Kitts and Nevis. Species per taxonomic group are listed in Table 13.

For each species more information was retrieved, to assess whether it would be a potential endemic (Table 13). We assess that reptile species are relatively well known and that few species are present, hence that no more new endemic reptile species should be expected. Also the endemic plant species from neighbouring islands concern species that grow sufficiently large to have been noticed by researchers in the past. For beetles, a very diverse group, more species are expected to be present (Peck, 2011). For spiders and scorpion species, a number of species was found on St. Barthélemy of which no or only very few related species are known to the Lesser Antilles. This suggest that the group is not yet well studied and that more species and perhaps endemics may be present. 
Table 12. Numbers of endemic species for the neighbouring islands of Anguilla, Anguilla Bank, St. Barthélemy, St. Martin and St. Kitts and Nevis. Totals and subtotals are shown per species group. Endemic species that are listed in the Dutch Caribbean Species Register are not included.

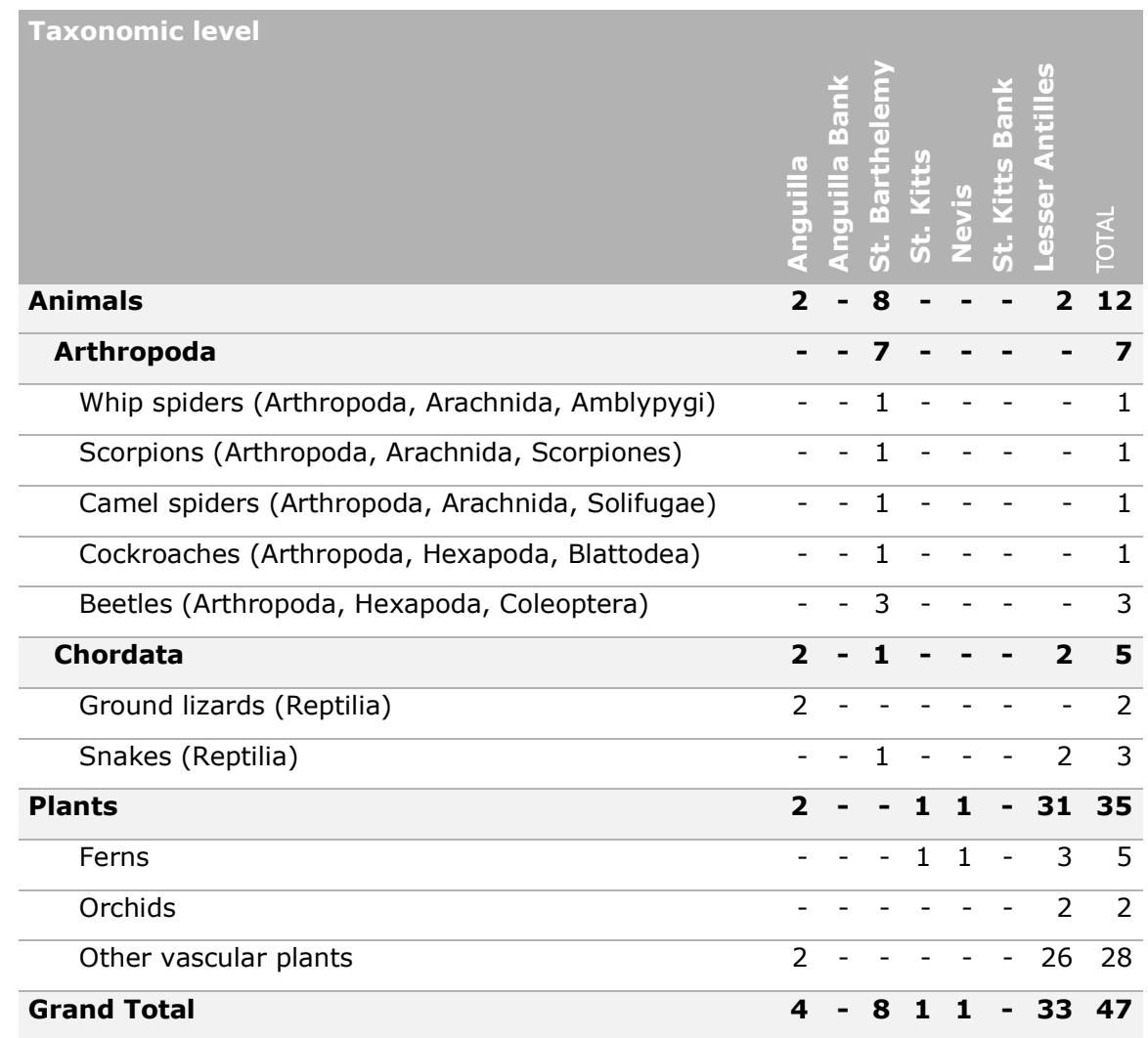


Table 13. Endemic species for Anguilla, Anguilla Bank, St. Barthélemy, St. Martin and St. Kitts and Nevis that are not mentioned in the Dutch Caribbean Species Register, and an assessment if they could be potential endemic to the SSS islands and Saba Bank.

\begin{tabular}{|c|c|c|c|}
\hline & Endemics per & Source & Potential endemic for SSS islands? \\
\hline & geographical area & & \\
\hline & $\begin{array}{l}\text { Endemic to } \\
\text { Anguilla }\end{array}$ & & \\
\hline \multirow[t]{2}{*}{$\begin{array}{l}\text { Reptiles and } \\
\text { amphibians }\end{array}$} & $\begin{array}{l}\text { Ameiva corvina (a } \\
\text { black ground } \\
\text { lizard): endemic to } \\
\text { Sombrero; }\end{array}$ & Procter \& Fleming (1999) & $\begin{array}{l}\text { A } 15 \mathrm{~cm} \text { size lizard. We assess that no similar } \\
\text { species on the SSS islands are present, given } \\
\text { their size and the small number of species } \\
\text { present on the islands. }\end{array}$ \\
\hline & $\begin{array}{l}\text { Ameiva corax (a } \\
\text { black ground } \\
\text { lizard): endemic to } \\
\text { Little Scrub Island }\end{array}$ & Procter \& Fleming (1999) & $\begin{array}{l}\text { A small lizard. We assess that no similar } \\
\text { species on the SSS islands are present (see } \\
\text { above). }\end{array}$ \\
\hline \multirow[t]{2}{*}{ Plants } & $\begin{array}{l}\text { Rondeletia } \\
\text { anguillensis } \\
\text { (Rubiaceae) }\end{array}$ & Procter \& Fleming (1999) & $\begin{array}{l}\text { Is endemic to Anguilla and not to other islands } \\
\text { (Bárrios \& Samuel, 2015). }\end{array}$ \\
\hline & $\begin{array}{l}\text { Evolvulus } \\
\text { arbuscula Poir. }\end{array}$ & Broome et al. (2007) & $\begin{array}{l}\text { On the SSS island, } 6 \text { species of Evolvulus are } \\
\text { known. Hence, we suppose that any extra } \\
\text { species would have been noticed already. }\end{array}$ \\
\hline
\end{tabular}

$\begin{array}{lll} & \begin{array}{l}\text { Endemic to St. } \\ \text { Barthélemy }\end{array} & \begin{array}{l}\text { INPN database } \\ \text { (https://inpn.mnhn.fr/collTe } \\ \text { treMer/977/BLM/tab/stats); } \\ \text { BEST 2016 }\end{array} \\ \text { Arthropods - } & \begin{array}{l}\text { Ammotrechella } \\ \text { beatriceae Teruel } \\ \text { \& Questel, 2011 }\end{array} \\ & \begin{array}{l}\text { Oiclus questeli } \\ \text { Teruel, 2008 }\end{array} \\ & \begin{array}{l}\text { Charinus bruneti } \\ \text { Teruel \& Questel, }\end{array} & \text { Figure 10. Ammotrechella }\end{array}$

Teruel \& Questel, 2011 beatriceae (Teruel \& Questel, 2011a)

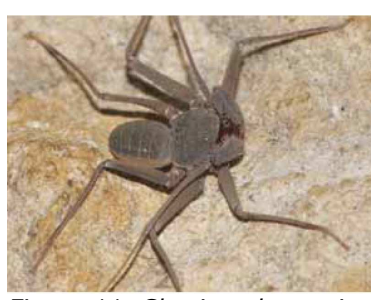

Figure 11. Charinus bruneti (Teruel \& Questel, 2011b)

\section{Ammotrechella beatriceae was only recently described as a new species (2011) (Figure 10). The authors (Teruel \& Questrel, 2011a) state that the order of Solifugae is very poorly studied in the Lesser Antilles. Therefore possible endemics are expected on the other islands of the Anguilla Bank (St. Martin and Anguilla).}

The scorpion Oiclus guesteli was only recently described (Teruel, 2008). It is estimated that on the SSS islands new endemics will not be present, because the fauna seems to be well studied. E.g. for St. Eustatius, the same author has described the whole of the scorpion fauna.

Charinus bruneti (Figure 11) is part of a welldiversified and widespread family of spiders (Charinidae) in the Greater Antilles. In the Lesser Antilles, its occurrence has been documented only a few times (Teruel \& Questel, 2011). Therefore, it is expected that possible endemics may be present on the SSS islands as well.

\begin{tabular}{|c|c|c|c|}
\hline $\begin{array}{l}\text { Arthropods - } \\
\text { insects }\end{array}$ & $\begin{array}{l}\text { Cratomorphus } \\
\text { dorsalis (Gyllenhal, } \\
\text { 1817) } \\
\text { Anthonomus } \\
\text { aestuans } \\
\text { (Fabricius, 1792) } \\
\text { Hemiblabera tristis } \\
\text { Bonfils, } 1969 \\
\text { Lachnopus } \\
\text { memnonius } \\
\text { (Gyllenhal, 1834) }\end{array}$ & $\begin{array}{l}\text { INPN database } \\
\text { (https://inpn.mnhn.fr/collTerr/ou } \\
\text { treMer/977/BLM/tab/stats); } \\
\text { BEST } 2016\end{array}$ & $\begin{array}{l}\text { Cratomorphus dorsalis and Anthonomus } \\
\text { aestuans are beetle species, described as a } \\
\text { single island endemic (Peck, 2011). We expect } \\
\text { there to be more beetle species present (see } \\
\text { above). } \\
\text { Hemiblabera tristis is a cockroach species, } \\
\text { described in } 1969 \text {. No further information as } \\
\text { found on how well studied this group is. } \\
\text { Lachnopus memnonius is a beetle described as } \\
\text { a single island endemic (Peck, 2011, 2016). } \\
\text { On St. Eustatius, a family member is present } \\
\text { (L. villosipes). Peck ( } 2011 \text { ) states however } \\
\text { that 'for the Northern Leeward islands, it is } \\
\text { evident that the beetle diversity is markedly } \\
\text { understudied, and that the actual number of } \\
\text { species is many times higher than now }\end{array}$ \\
\hline
\end{tabular}




\begin{tabular}{|c|c|c|c|}
\hline \multirow[t]{2}{*}{ Reptiles } & $\begin{array}{l}\text { Antillotyphlops } \\
\text { annae (Typhlops } \\
\text { de St. Barths) } \\
\text { (Breuil, 1999) } \\
\text { Typhlops de Saint- } \\
\text { Barthélemy }\end{array}$ & $\begin{array}{l}\text { INPN database } \\
\text { (https://inpn.mnhn.fr/collTerr/ou } \\
\text { treMer/977/BLM/tab/stats); } \\
\text { BEST } 2016\end{array}$ & $\begin{array}{l}\text { See above, no new endemic reptile species are } \\
\text { expected to be found. }\end{array}$ \\
\hline & $\begin{array}{l}\text { Endemic to St. } \\
\text { Kitts }\end{array}$ & & \\
\hline \multirow[t]{2}{*}{ Plants } & $\begin{array}{l}\text { Asplenium } \\
\text { malcolm-smithii } \\
\text { (believed to be a } \\
\text { hybrid endemic to } \\
\text { St. Kitts) }\end{array}$ & Horwirth \& Lindsay (1999) & $\begin{array}{l}7 \text { Asplenium species are present on the SSS } \\
\text { Islands. Based on that number, it is expected } \\
\text { that they have been well studies. No other } \\
\text { endemic species are expected. }\end{array}$ \\
\hline & Endemic to Nevis & & \\
\hline \multirow[t]{2}{*}{ Plants } & $\begin{array}{l}\text { Thelypteris. } \\
\text { muscicola }\end{array}$ & Horwirth \& Lindsay (1999) & $\begin{array}{l}12 \text { family members (Thelypteridacaea) are } \\
\text { present on the SSS Islands. Based on that } \\
\text { number, it is expected that they have been } \\
\text { well studied. No other endemic species are } \\
\text { expected. }\end{array}$ \\
\hline & $\begin{array}{l}\text { Endemic to } \\
\text { Lesser Antilles } \\
\text { (and present on } \\
\text { Nevis and/or St. } \\
\text { Kitts and/or St. } \\
\text { Barthelomy) }\end{array}$ & & \\
\hline \multirow[t]{2}{*}{ Reptiles } & $\begin{array}{l}\text { Typhlops monastus } \\
\text { (a blind snake) }\end{array}$ & Horwirth \& Lindsay (1999) & $\begin{array}{l}\text { See above, no new endemic reptile species are } \\
\text { expected to be found. }\end{array}$ \\
\hline & $\begin{array}{l}\text { Typhlops. } \\
\text { monastus } \\
\text { geotomus } \\
\text { (subspecies of the } \\
\text { blind snake) }\end{array}$ & Horwirth \& Lindsay (1999) & $\begin{array}{l}\text { See above, no new endemic reptile species are } \\
\text { expected to be found. }\end{array}$ \\
\hline \multirow[t]{3}{*}{ Plants (ferns) } & $\begin{array}{l}\text { Hymenophyllum } \\
\text { hirtellum var. } \\
\text { gratum }\end{array}$ & Horwirth \& Lindsay (1999) & Remains to be checked \\
\hline & $\begin{array}{l}\text { Thelypteris } \\
\text { antillana }\end{array}$ & Horwirth \& Lindsay (1999) & See T. muscicola \\
\hline & $\begin{array}{l}\text { Thelypteris } \\
\text { clypeolutata }\end{array}$ & Horwirth \& Lindsay (1999) & See T. muscicola \\
\hline \multirow[t]{2}{*}{ Plants (orchids) } & $\begin{array}{l}\text { Stelis scabrida } \\
\text { (orchid species) }\end{array}$ & Horwirth \& Lindsay (1999) & $\begin{array}{l}\text { Given that orchid species are likely to attract } \\
\text { attention of plant specialist, we estimate that } \\
\text { this species is not present on the SSS islands. }\end{array}$ \\
\hline & $\begin{array}{l}\text { Ponthieva petiolata } \\
\text { Lindl. }\end{array}$ & Broome et al. (2007) & See S. scabrida \\
\hline \multirow[t]{14}{*}{$\begin{array}{l}\text { Plants (other } \\
\text { vascular plants) }\end{array}$} & Asplundia insignis & Broome et al. (2007) & $\begin{array}{l}\text { Flowering plant, quite large. Probably } \\
\text { therefore not overlooked. }\end{array}$ \\
\hline & $\begin{array}{l}\text { Charianthus } \\
\text { umbrosa }\end{array}$ & Horwirth \& Lindsay (1999) & No information was found for this species \\
\hline & $\begin{array}{l}\text { Chromolaena } \\
\text { integrifolia }\end{array}$ & Broome et al. (2007) & $\begin{array}{l}\text { Blue flowering plant. Probably therefore not } \\
\text { overlooked. }\end{array}$ \\
\hline & $\begin{array}{l}\text { Chromolaena } \\
\text { trigonocarpa }\end{array}$ & Broome et al. (2007) & $\begin{array}{l}\text { White flowering plant. Probably therefore not } \\
\text { overlooked. }\end{array}$ \\
\hline & $\begin{array}{l}\text { Chrysobalanus } \\
\text { cuspidatus }\end{array}$ & Broome et al. (2007) & $\begin{array}{l}\text { Tree/bush like. Probably not overlooked } \\
\text { because of its size. }\end{array}$ \\
\hline & $\begin{array}{l}\text { Connarus } \\
\text { grandifolius }\end{array}$ & Broome et al. (2007) & Vine. No other information available. \\
\hline & Crantzia cristata & Broome et al. (2007) & $\begin{array}{l}\text { Conspicuous coloured flowers. Probably not } \\
\text { overlooked. }\end{array}$ \\
\hline & $\begin{array}{l}\text { Cybianthus } \\
\text { parasiticus }\end{array}$ & Horwirth \& Lindsay (1999) & $\begin{array}{l}\text { Small plant, probably not easily overlooked. } \\
\text { (http://ecflora.cavehill.uwi.edu/plantdetails.ph } \\
\text { p?pid=1500\&sn=Cybianthus+parasiticus\&cn= } \\
\text { \&gh=shrub) }\end{array}$ \\
\hline & Euphorbia balbissii & Broome et al. (2007) & Remains to be checked. \\
\hline & Guzmania dussii & Broome et al. (2007) & Remains to be checked. \\
\hline & $\begin{array}{l}\text { Illex macfadyenii } \\
\text { ovata }\end{array}$ & Broome et al. (2007) & Remains to be checked \\
\hline & Lobelia circiifolia & Horwirth \& Lindsay (1999) & $\begin{array}{l}\text { A species of flowering plant. Probably } \\
\text { therefore not overlooked. }\end{array}$ \\
\hline & Lobelia stricta & Broome et al. (2007) & See L. circiifolia \\
\hline & $\begin{array}{l}\text { Malpighia } \\
\text { martinicensis }\end{array}$ & Broome et al. (2007) & $\begin{array}{l}\text { Shrub/tree like. Pink/white flowers. Probably } \\
\text { not overlooked because of its size and colours. }\end{array}$ \\
\hline
\end{tabular}


Miconia globuliflora Broome et al. (2007)

var. dominicae

Peperomia dussii

Broome et al. (2007)

Horwirth \& Lindsay (1999)

Peperomia trifolia

Piper dussii

Horwirth \& Lindsay (1999)

Broome et al. (2007)

Pitcairnia bifrons

Broome et al. (2007)

Rubus ferrugineus Broome et al. (2007)

Sapium

Horwirth \& Lindsay (1999)

glandulosum (L.)

Morong (syn.

Sapium

caribaeum)

Schefflera

Horwirth \& Lindsay (1999)

attenuata
Ocotea alpina

No information available.

Tree or tree-like. Probably not overlooked because of its size.

21 other species within the Piperaceae family are present on the SSS islands, hence we estimate that the flora is well studies and that this species is not present.

See Pepromia dussii

5 other Piper species are present in the species register. Therefore it is expected that another one would not have been overlooked. Large plant with red flowers. Would probably not have been overlooked. However, no other Pitcairnia species are registered.

Rose family, probably with berries. No other information was found.

A large tree, $\max 30 \mathrm{~m}$ in height. A tree this size is probably not overlooked by botanists. We estimate that this species is not present on the SSS islands

(http://biogeodb.stri.si.edu/biodiversity/bci/sp ecies/24327)

A tropical plant, probably not easily overlooked. Hence, we expect no new endemic species

(http://ecflora.cavehill.uwi.edu/plantdetails.ph p?pid $=189 \& s n=$ Schefflera + attenuata $\& \mathrm{cn}=$ arali e+montagne $\% 2 \mathrm{C}+$ fidjier $\% 2 \mathrm{C}+$ mapou+blanc $\%$ $2 \mathrm{C}+$ trompette $+\mathrm{a}+$ canon $\% 2 \mathrm{C}+$ trompette+blan $\mathrm{c} \% 2 \mathrm{C}+$ White+elder\&gh $=$ tree + or + tree-like $)$.

\section{Sloanea dentata \\ Horwirth \& Lindsay (1999) (syn.}

S. massoni)

Styrax glaber

Horwirth \& Lindsay (1999)

A large tree, see above.(

http://ecflora.cavehill.uwi.edu/plantdetails.php ?pid $=835 \& s n=$ Sloanea + dentata $\& \mathrm{cn}=\& \mathrm{gh}=$ ) Small plant, probably not easily overlooked (http://ecflora.cavehill.uwi.edu/plantdetails.ph $\mathrm{p}$ ? pid $=2276 \& \mathrm{sn}=$ Styrax + glaber $\& \mathrm{cn}=$ bois + dore $\% 2 \mathrm{C}+$ bois + madame $\% 2 \mathrm{C}+$ crump + wood $\% 2 \mathrm{C}+$ cypre-orange $\% 2 \mathrm{C}+$ Laurier-

caraibe $\% 2 \mathrm{C}+$ laurierorange $\% 2 \mathrm{C}+$ oranger+des + bois $\& \mathrm{gh}=$ tree + or + tree-like)

Ternstroemia Horwirth \& Lindsay (1999) elliptica easily overlooked. (http://www.tropical.theferns.info/viewtropical .php?id=Ternstroemia +elliptica) 


\subsection{Endemic taxa (species and subspecies) per species group}

The most important species groups are discussed in alphabetic order of the taxonomic groups.

\subsubsection{Worms (Annelids-polychaetes)}

35 species of annelids (of which 26 polychaete species) are registered in the Dutch Caribbean Species Register for the SSS islands and Saba Bank. Potentially, one species of polychaetes could be an endemic species, since this taxon has only been described for St. Eustatius and Jamaica (Namanereis sublittoralis Glasby, 1999) (Figure 12), but it was never investigated any further. Reanalysis of the specimen should take place to ensure that this is a genuine endemic or a misidentification (e.g. the distance between St. Eustatius and Jamaica is rather large). For

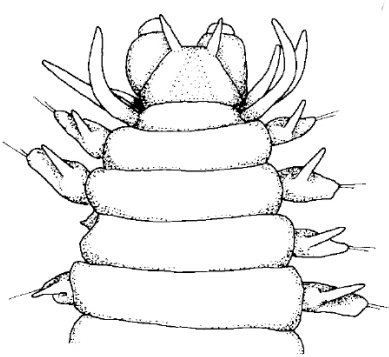

$0.2 \mathrm{~mm}$

Figure 12. Head part of Namanereis sublittoralis (source: Glasby, 1999). now, we have listed this species as endemic however.

\subsubsection{Arthropods (Arthropoda)}

\section{Spiders and scorpions (Arachnida)}

127 species of spiders and scorpions are registered for the SSS islands (see list in Annex 1), of which 4 are endemic to the SSS islands, including 1 spider Stenoonops saba on Saba, and 3 species of pseudoscorpions, one on each island (St. Martin: Amblyolpium martinensis, Saba: Corticochernes sabae; St. Eustatius Pachyolpium confusum). Pseudoscorpions are very small (max a few mm) members of the arachnids with flat pear shaped bodies. No clear illustrations of these species could be found. Key references for this group include the Van den Tooren (2008), BEST (2016) and the World Spider Catalog (2018).

\section{Copepods (Hexanauplia)}

Of the 13 species of Hexanauplia, 2 are endemic to St. Martin. One is the $0.5 \mathrm{~mm}$ harpacticoid copepod Leptocaris faber (Figure 13). It was discovered in 1978 during the West Indian Expeditions of the University of Amsterdam (Fiers, 1986). The other one is Acanthomolgus seticornis.

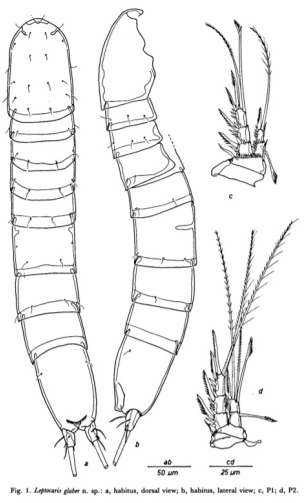

Figure 13. Endemic to St. Martin: the copepod Leptocaris faber $(0.5 \mathrm{~mm})$ (Fiers, 1986). 


\section{Beetles (Insecta - Coleoptera) and true bugs (Insecta - Hemiptera)}

Beetles are one of the most diverse species groups on Earth. In the Lesser Antilles, 2612 recognized species are present (Peck 2016). In the species register, 122 species are present on the SSS islands, with 33 endemic species in total: For St. Martin, 2 island endemics are registered (Phyllophaga stehlei; Solenoptera chalumeaui) and for Saba 1 island endemic, the jewel beetle Chrysobothris sabae (Figure 14). The remaining 30 species are endemic on the level of the Lesser Antilles. Peck (2011) states that 'for the Northern Leeward islands, it is evident that the beetle diversity is markedly understudied, and that the actual number of species is many times higher than now known'. In Peck (2016) estimates are given for potential number of beetles species present on the SSS islands: these are 442 for Saba, 518 for St. Eustatius and 784 for St. Martin. We therefore expect there to be more endemics present on the SSS islands.

One species of true bugs (Hemiptera) is unique to Saba: Lophoscutus geijskesi (Kormilev \& Van Doesburg 1986, via http://Intreasures.com/saba.html) (Figure 15), 2 others are unique to the Lesser Antilles.

Literature used to check the species register for endemics includes Yokoyama (2013) and Peck (2016).

\section{$\underline{\text { Flies (Insecta - Diptera) }}$}

Of the 25 species of flies on the SSS islands, 1 is probably unique to Saba: a moth fly (Alepia apexalba), associated to tank bromeliads (Wagner et al., 2010, via http://Intreasures.com/saba.html). Three species are endemic to the Lesser Antilles and 2 also to the Greater Antilles: the mosquito Aedes busckii, and 2 hoverflies Allograpta limbata (Figure 16) and Ocyptamus cylindricus.

Butterflies and moths (Insecta-Lepidoptera): no island endemics were found, and 6 endemics are present on a larger level. Literature used to check the species register for endemics includes Hill (2012), Yokoyama (2013) and www.butterfliesofamerica.com.

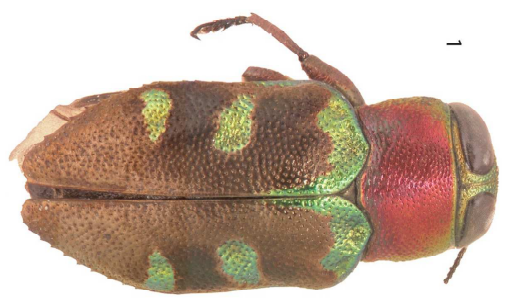

Figure 14. The jewel beetle Chrysobothris sabae, endemic to Saba, and first described in 2013 by Maier \& Ivie (photo: Maier \& Ivie, 2013).

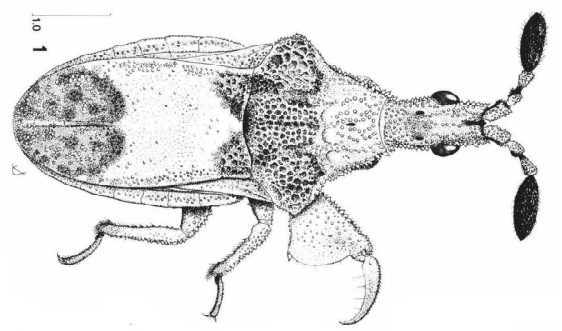

Figure 15. An ambush bug Lophoscutus geijskesi, endemic to Saba, (photo: Kormilev \& Van Doesburg, 1986).

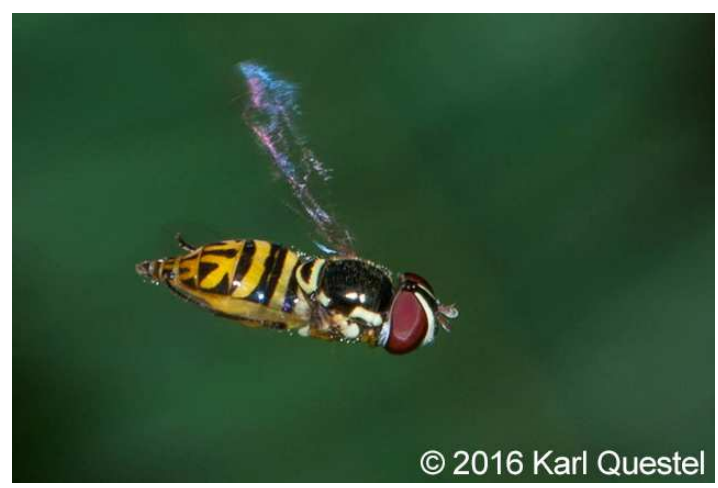

Figure 16. Hoverfly Allograpta limbata, endemic to the Lesser and Greater Antilles (photo: Karl Questel, source http://biodiversiteantilles.blogspot.com/2018/02/allograptalimbata.html). 


\section{Grasshoppers, locusts and crickets (Insecta - Orthoptera)}

In total, 32 species of Orthoptera occur on the SSS islands, with a high total number of 22 endemics: 10 islands endemics, 1 endemic on the level of the Northern Lesser Antilles and 9 on the level of the Lesser Antilles (see Annex 1). Both St. Eustatius ( 5 island endemics) and Saba (4 island endemics) have high numbers of island endemics compared to St. Martin ( 1 species). An example is the Saba endemic cricket Antillicharis sabaensis, first described only a decade ago in 2009. Illustrations could not be found. Literature used to check the species register for endemics includes Otto (2009) and Bland \& Desutter-Grandcolas (2003).

Crabs, lobsters, shrimps (Decapoda)

Of the 227 species of crabs, lobsters and shrimps on the SSS islands, 1 is registered as endemic to the Lesser Antilles: Thersandrus compressus, a small crab species (Figure 17).

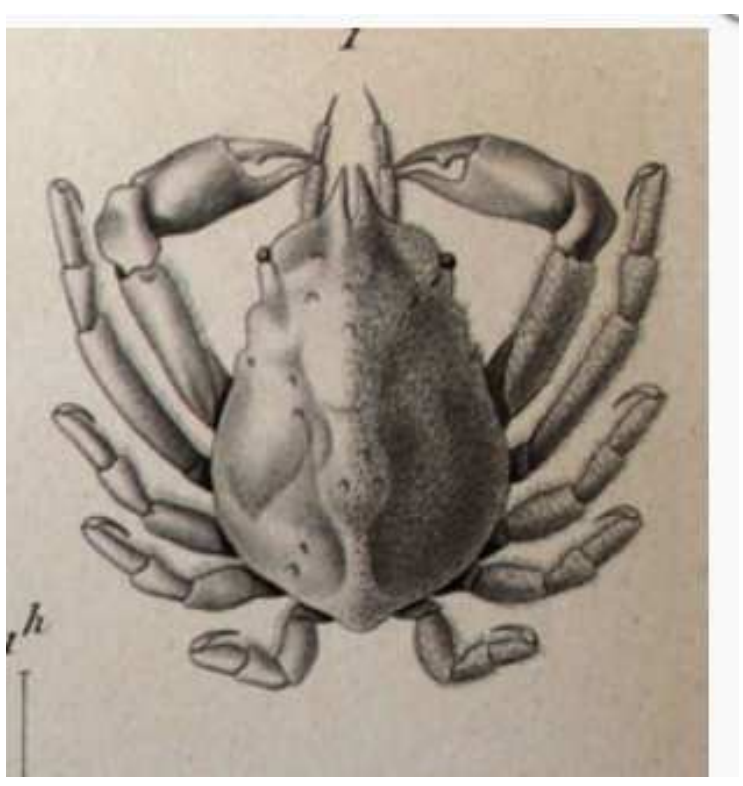

Figure 17. Endemic to the Lesser Antilles: a small crab Thersandrus compressus (source: crustiesoverseas.free.fr photo: Poupin, image by Desbonne \& Schramm, 1867). 


\subsubsection{Bony fish (Chordata - Actinopterygii)}

In total 420 species of bony fish are registered on the SSS islands and Saba Bank, of which 3 endemics to the region: 1 is endemic to Saba Bank: William's blenny (Starksia williamsi) (Figure 18), 1 to Oyster Pond, St. Martin (St. Maarten pejerry Melanorhinus boekei), and 2 species to the Lesser Antilles.

FishBase was used to check the species register

Figure 18. Endemic to Saba Bank: William's blenny, female (Starksia williamsi) (photo: Jeffrey Williams, FishBase). for endemics (Froese \& Pauly 2018).

\subsubsection{Birds (Chordata - Aves)}

In total 232 species of birds are registered for the SSS islands and Saba Bank (Annex 1) of which 23 endemics. No island endemics are present, 2 subspecies of Passerines (Passeriformes) are endemic to the Northern Lesser Antilles (Cinclocerthia ruficauda pavida, Brown Trembler (Figure 19); Loxigilla noctis coryi, Lesser Antillean Bullfinch) and 21

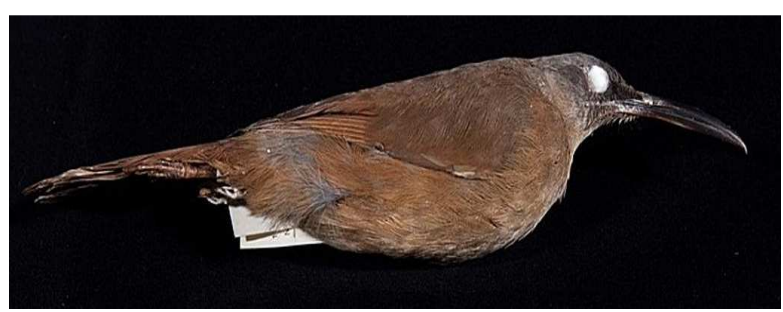

Figure 19. Preserved specimen of Cinclocerthia ruficauda pavida (Naturalis Biodiversity Center). to the Lesser Antilles (see Annex 1). For St. Kitts, a few now-extirpated bird species are described in Horwirth \& Lindsay (1999), including the St. Kitts Bullfinch and an owl species. Literature used in this report to check for endemic species in the species register includes Del Hoyo \& Collar (2014, 2016).

\subsubsection{Amphibians (Chordata - Amphibia)}

In total 4 species of amphibians are present on the SSS islands, 1 of them endemic to the Lesser Antilles, but introduced to the SSS islands (van Buurt et al 2012).

The lesser Antillean whistling frog Eleutherodactylus johnstonei (Figure 20) is originally endemic to the Lesser Antilles, but has been introduced to a much wider area in the Caribbean

(http://www.iucnredlist.org/details/56684/0). A key reference used to check the species

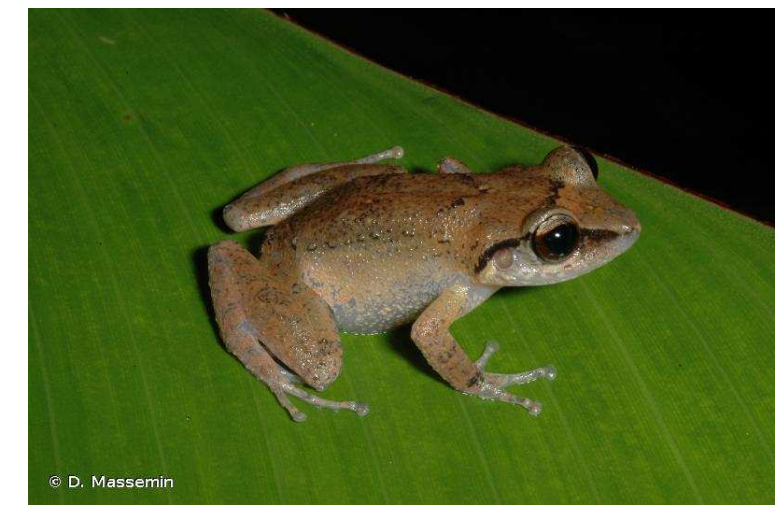
register for endemics is Powell et al (2015). 


\subsubsection{Sharks, rays (Chordata - Chondrichthyes)}

In total 24 species of sharks and rays are present around the SSS islands and Saba Bank of which 1 is endemic to the Lesser and Greater Antilles, the Antilles catshark (Galeus antillensis Springer, 1979), a deep water (293-296 m) species of max $46 \mathrm{~cm}$ length (Heupel, 2009) (Figure 21). FishBase was used to check the species register for endemics (Froese \& Pauly

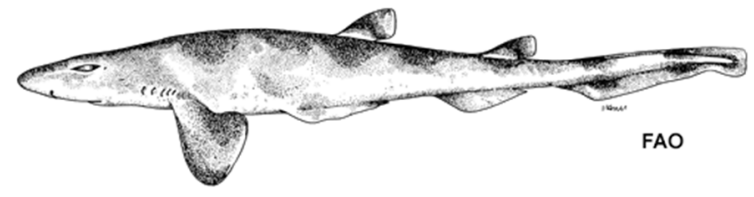

Figure 21. Antilles catshark Galeus antillensis (drawing: $F A O)$. 2018).

\subsubsection{Mammals (Chordata - Mammalia)}

In total 30 species of mammals are present on and around the SSS islands and Saba Bank among which 11 species of bats (Chiroptera), the only group of terrestrial mammals that have not been introduced to the islands. All other terrestrial species such as goats, rats, mongoose have been introduced by man. Furthermore, this group consists of widespread marine mammals. Of the bat species, 5 are endemic to the Lesser Antilles (see Annexes 1 and 2).

\subsubsection{Reptiles (Chordata - Reptilia)}

In total 37 species of reptile species are present on the SSS islands and Saba Bank, according to the Dutch Caribbean Species Register (Annex 1): 30 snake and lizard species (Squamata) and 7 species of turtles. Endemics are listed in Annex 1. The three island endemics are the Saban anole (Anolis sabanus) at Saba (Figure 22), Spondylurus martinae (St. Martin) and Thecadactylus oskrobapreinorum (St. Martin). Furthermore, there is 1 endemic reptile species on the level of the Anguilla Bank, the endangered Anguilla Bank racer (Alsophis rijgersmaei), 1 on the level of the St Kitts bank (Anolis schwartzi), a snake species that is probably extirpated on the island of St. Martin but is present at Anguilla and St. Barths (source: Dutch Caribbean Species Register). In addition, there are 12 endemic reptile species for the Lesser Antilles, such as the endangered Lesser Antillean Iguana (Iguana delicatissima Laurenti, 1768) (Figure 23).

Finally, as described in the Introduction, a melanistic form of $I$. iguana is present on

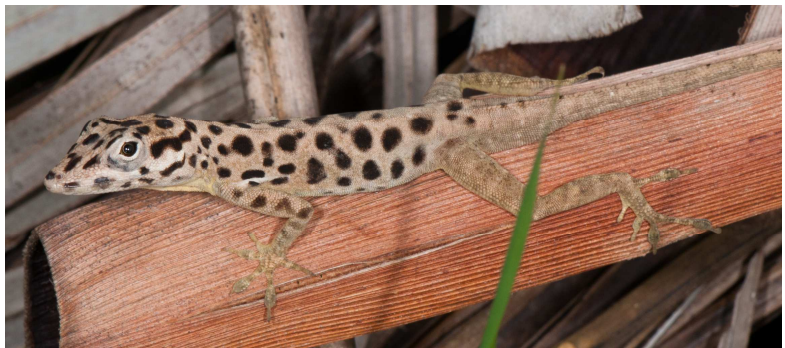

Figure 22. Island endemic to Saba: the Saban anole (Anolis sabanus) (Photo: Mark Yokoyama via Dutch Caribbean Species Register).

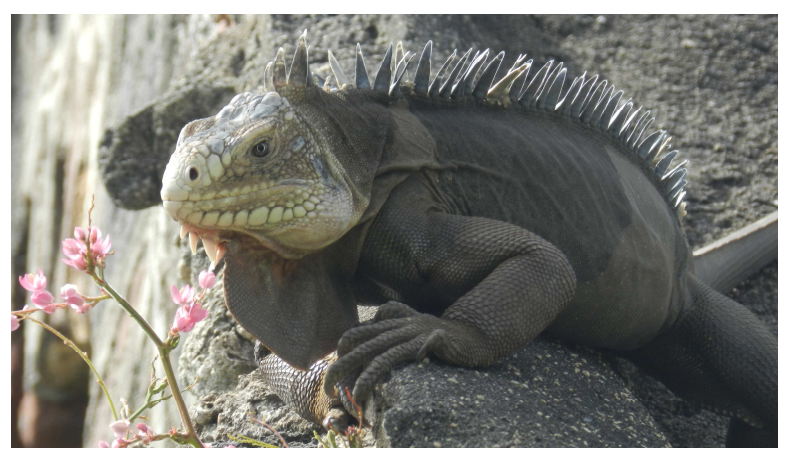

Figure 23. Endemic to the Lesser Antilles: the Lesser Antillean Iguana (Iguana delicatissima) (photo: Frank van Spelde, via www.dutchcaribbeanspecies.org). 
Saba which is considered to be a separate lineage within the green iguana (Brueil 2013, Stephen et al. 2013). Since it is has not yet been described as a separate species or subspecies, it is not considered any further in this report.

Literature used to check the species register for endemics included Powell et al (2015).

\subsubsection{Anemones, hydrozoans, corals and jellyfish (Cnidaria)}

In total, 159 species of Cnidarians are registered for the SSS islands and Saba Bank, of which only 1 species is endemic to the Lesser Antilles (Antillogorgia hummelincki, syn. Pseudopterogorgia hummelincki, a soft coral species) (no illustration found) and 4 species to the Greater Antilles (see Annex 1) (1 soft coral Antillogorgia albatrossae, 2 species of zoanthids Bergia puertoricense and Hydrozoanthus tunicans (Zoantharia) (Figure 24) and a hydrozoan (Heterocoryne caribbensis).

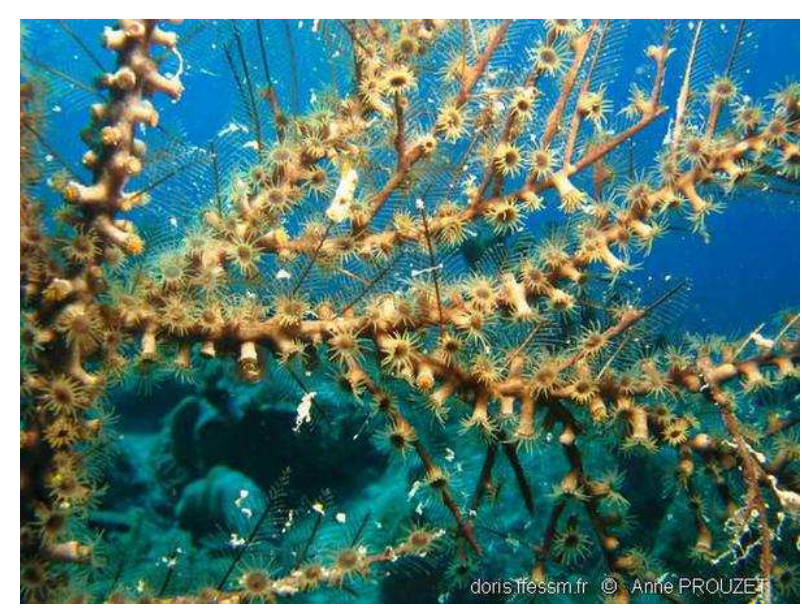

Figure 24. Hydrozoanthus tunicans (photo: Anne Prozet, source : http://doris.ffessm.fr/Especes/Zoanthaires-des-Hydraires3).

\subsubsection{Bivalves, snails, squid, chitons and tusk shells (Mollusca)}

In total, 135 species of bivalves, 507 snails (Gastropoda), 5 squid and octopus species (Cephalopoda), 15 chitons (Polyplacophora) and 5 species of tusk shells (Scaphopoda) are registered for SSS islands and Saba Bank. 33 species of bivalves (5) and gastropods (28) are endemic. There are 3 island endemic gastropod species: Glyphyalus quillensis (St. Estatius, Figure 25), Lyria sabaensis (Saba; Bail, 1993 ; source:

http://Intreasures.com/saba.html) and Conasprella berschaueri (St. Martin). An example of an endemic bivalve on the level of the Lesser Antilles is Parvilucina latens a new species that was found around Guadeloupe (Figure 26). Literature used by the species specialists includes Yokoyama (2013), BEST (2016), Neckheim \& Hovestadt (106) an WoRMS Editorial Board (2018).

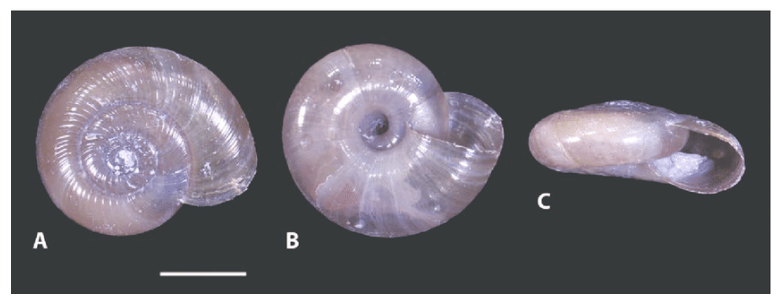

Figure 25. Endemic gastropod to St. Eustatius: Glyphyalus quillensis (photo: Van Leeuwen et al., 2016).

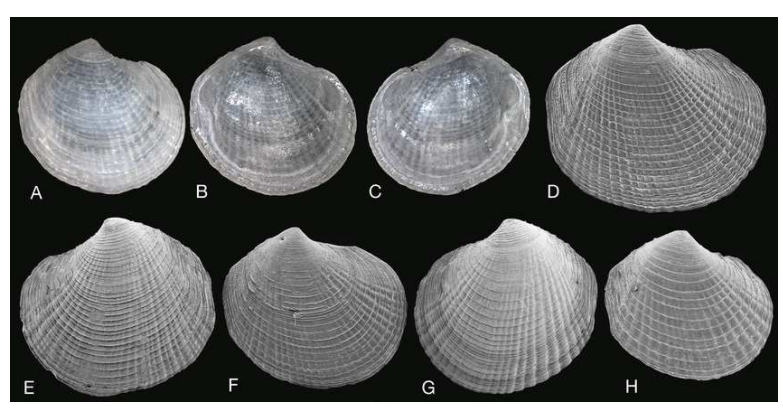

Figure 26. Newly discovered endemic bivalve to the Lesser Antilles: Parvilucina latens (Taylor \& Glover, 2016). 


\subsubsection{Flatworms (Platyhelminthes)}

Of the 5 registered species of flatworms, 1 endemic species is known for the Lesser Antilles: Alloioplana wyona (Du Bois-Reymond Marcus \& Marcus, 1968) (Figure 27). Literature used by the species specialists includes WoRMS Editorial Board (2018).

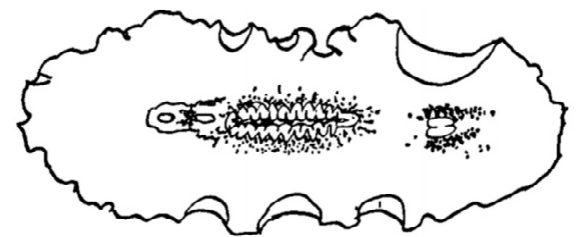

Figure 27. Flatworm endemic to the Lesser Antilles: Alloioplana wyona (source: Du Bois-Reymond Marcus \& Marcus, 1968).

\subsubsection{Sponges (Porifera)}

No sponge species were found to be restricted in known distribution to the islands or Saba Bank nor to a narrow region around this island group.

\subsubsection{Wheel animals (Rotifera)}

Within the 20 species of wheel animals, no endemic species are yet recognized. 


\subsubsection{Red algae, green algae and vascular plants (Plantae)}

Of the 1453 plants species registered for the SSS islands and Saba Bank, 4 species are endemic to the SSS islands, 4 to the Northern Lesser Antilles, 14 to the Lesser Antilles and 4 tot the Antilles (Annexes 1,2). The 4 island endemics include 1 red alga Stichothamnion antillarum for St. Eustatius (Figure 28), 1 terrestrial vascular plants on St. Eustatius: a species of climbing milkweed Gonolobus aloiensis (Figure 29). On St. Martin (Dutch+French part), 2 island endemics are known, but both of which are thought to be extinct at St. Martin (the vine Galactia nummularia, and another flowing plant Calypthranthes boldinghii). Future, more exhaustive research could demonstrate whether this is the case or not. Previous research has taken place with a limited effort (e.g. a limited number of sites). New research has shown that Statia Morning Glory Ipomoea sphenophylla (Figure 30) that was first thought to be an island endemic for St. Eustatius, is also present on Anguilla (hence classified in this report as endemic on the level of the Northern Lesser Antilles) (Axelrod, 2017).
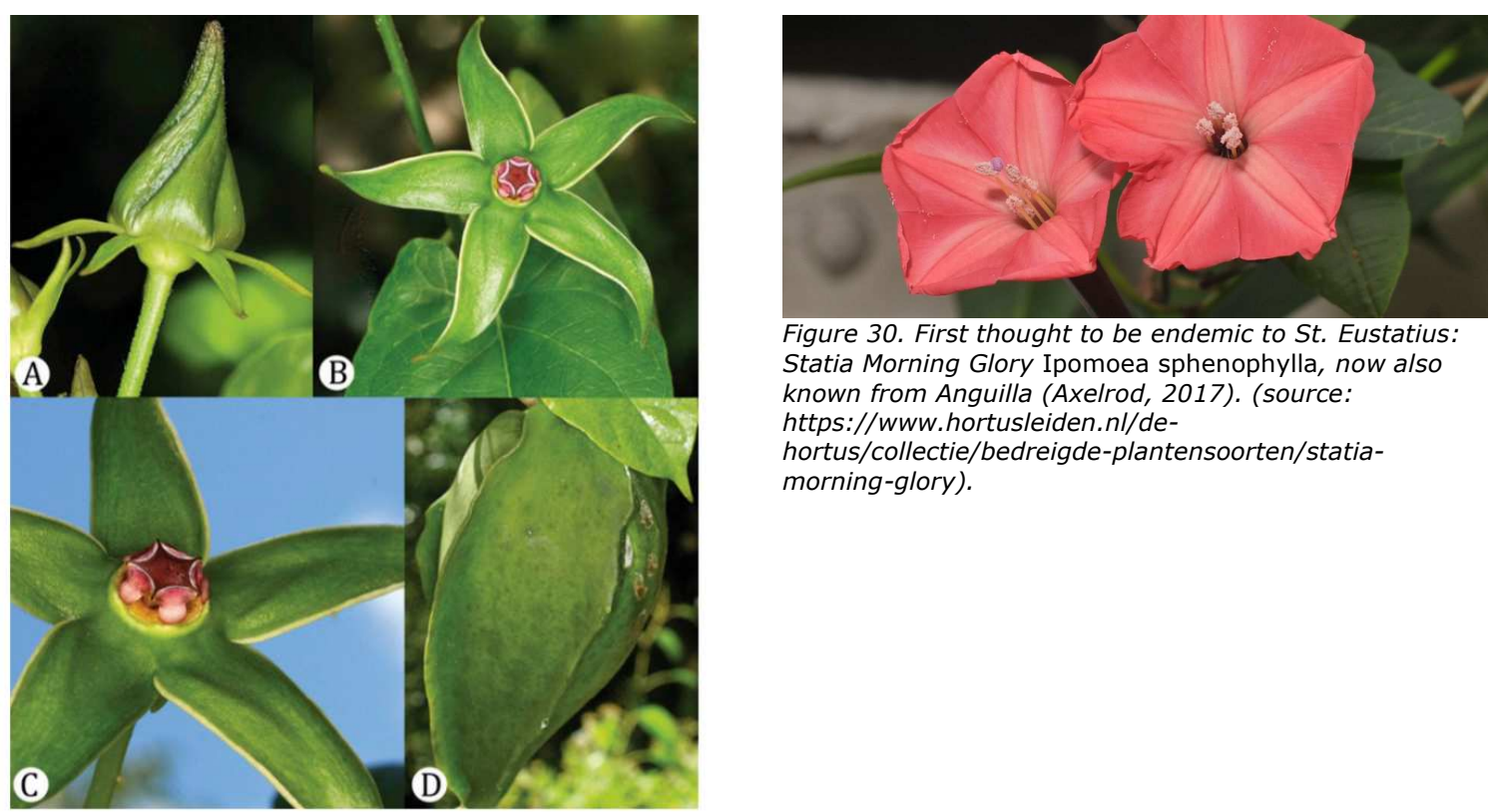

Figure 30. First thought to be endemic to St. Eustatius: Statia Morning Glory Ipomoea sphenophylla, now also known from Anguilla (Axelrod, 2017). (source: https://www.hortusleiden.nl/de-

hortus/collectie/bedreigde-plantensoorten/statiamorning-glory).

Figure 29.Endemic to St. Eustatius: a climbing milkweed Gonolobus aloiensis (source: Krings \& Axelrod, 2013). 


\subsection{IUCN Conservation status}

The list of endemic taxa for the SSS islands and Saba Bank contains 222 (sub)species. Most of these (sub)species are not being monitored by IUCN or other parties, which explains that the IUCN conservation status could only be assessed for 42 of them at species level (none at subspecies level) and all belonging to the phylum Chordata. For 16 taxa at subspecies level the assessment at the species level as shown in Annex 3 is therefore probably not accurate. Only 6 of the assessed species have a threatened or near threatened status according to IUCN (for full list see Annex 3):

- Critically Endangered: Lesser Antillean Iguana (Iguana delicatissima). Within the SSS-islands this iguana species is only present at St. Eustatius, while it's extinct on St. Martin. Its IUCN conservation status has recently (March 2018) been 'upgraded' to Critically Endangered due to increasing occurrence and rate of hybridization and island extirpations.

- Endangered: Anguilla Bank Racer (Alsophis rijgersmaei) and Anguilla Bank Skink (Spondylurus powelli). Within the SSS-islands the snake species Anguilla Bank Racer was only present on St. Martin, where it is extinct now. It is listed as Endangered on the basis that this species currently only survives on five other islands, from which only one (St. Barths) is considered to have a viable population. Within the SSS-islands the Anguilla Bank Skink (Spondylurus powelli) was presumably once present at St. Martin, though extensive searches in suitable rock walls on this island have never recorded it. The species is listed as Endangerd on the basis that it has a restricted extent of occurence (only four islands on the Anguilla Bank) and that it's population is assumed to decline (Hedges et al., 2017).

- Vulnerable: Saba Racer (Alsophis rufiventris) and Anguilla Bank Bush Anole (Anolis pogus). Within the SSS-islands the Saba Racer (also known as Red-bellied Racer) still exists at Saba and St. Eustatius. It is extinct at St. Maarten. This snake species is listed as Vulnerable on the basis of a plausible future threat mainly from mongoose introduction, which has led to its extinction on other islands. The Anguilla Bank Bush Anole (Anolis pogus) is only present at St. Martin. No information is available regarding current threats to this lizard species. In the past, they have occurred on Barthélémy and Anguilla.

- Near threatened: St. Christopher Ameiva (Pholidoscelis erythrocephalus). Within the SSSislands this lizard only exists at St. Eustatius. It is listed as Near Threatened on the basis that the species is restricted to the three islands of the St. Kitts Bank. On St. Kitts and Nevis, it is threatened by mongoose.

It is important to realize that the degree of endangerment of the 223 endemic species and subspecies listed here for the windward Dutch SSS islands is grossly under-represented by the IUCN listings. Many species only survive in small, fragmented populations on few islands and may even already gone extinct. 


\section{Conclusions and recommendations}

This report provides a preliminary checklist of extant endemic animal and plant taxa (species and subspecies) of the SSS islands and Saba Bank. The list is not complete yet, because a number of species groups were left out and not all available information could be thoroughly checked. In addition, an unknown number of endemic species remain to be identified or described. Apart from that, the checklist shows that the SSS islands and Saba Bank are important in terms of biodiversity, because at least 35 island endemic species are present. Island endemics are defined in the report as species that are unique to one (but not more) of the SSS islands or to the Saba Bank and that are thus not found anywhere else in the world. Furthermore, the SSS islands and Saba Bank are part of the range of 188 other Caribbean endemics that also have an otherwise very limited distribution. Species that are limited to a single island or to small unviable populations on a small cluster of islands are extremely vulnerable to being erased from the globe by unfortuitous events like hurricanes or volcanism or by superior competition or predation by invasive species.

As indicated in the introduction, the West Indies are a hotspot of endemism but also a hotspot in terms of extinction threat to this unique biodiversity (Leclerc et al 2018). In addition, local endemics have been typically under-assessed by the IUCN (Leclerc et al. 2018) with as a consequence that few of these most vulnerable species are recognized as being endangered. Hence most conservation effort is actually dedicated to more-widely ranging and less-endemic species. Therefore, research is urgently needed to assess the status of these endemic taxa on the different islands on which they are found.

\subsection{Number of endemics}

In this study 198 endemic animal and 25 plant species were identified, out of the 4114 animal and plant species registered in the Dutch Caribbean Species Register for the SSS islands and Saba Bank. Of the 223 endemics, 35 are considered island endemics (restricted to only one of the SSS islands or Saba Bank) and 188 species are endemic to a larger region. It is expected that these numbers are an underestimation, since several species groups, including Funghi (e.g. mushrooms) and Chromista (e.g. brown algae) were not studied. In this study, the percentage of marine endemics $(2 \%)$ is much lower than of terrestrial endemics ( $8 \%)$. This can be expected on the scale of this study, since the islands are relatively isolated from each other, while the marine environment around the islands is all connected.

Another reason why the numbers of endemics are underestimated is that new species have been found, which may represent (island) endemics. For the fish fauna of Saba Bank, the species accumulation curve of Williams et al. (2010) suggests that another 50-140 species could be present in addition to the 270 species found by those authors. We expect that in addition to the 6 unidentified species of Williams et al. (2010), many more undescribed species are present that also could be endemic. For sponges, diversity was studied during the Saba Bank Expedition 2015 (see Bos et al., 2016), yielding at least one or two undescribed sponge species (Wilting et al. in prep.), within only a few days of diving. More undescribed species are undoubtedly present. Littler et al. (2010) show that Saba Bank is the most diverse area for algae in the Caribbean. They identified 12 undescribed (and possibly endemic) algal species (brown algae, belonging to the kingdom of Chromista, not studied in this study) out of nearly 100 identified species. Based on an estimated 150-200 species likely present (using species area curves), it is therefore almost certain that more species will eventually be described.

For the terrestrial species, we expect that well-visible or easily sampled species such as lizards, snakes, birds, amphibians, and plant species have been well researched and will yield fewer new endemic taxa. For the smaller and less mobile species, such as certain groups of insects, spiders and small snails, we expect that more species could be present than currently registered, since they could 
have easily been overlooked. For example, more endemic beetles may be present, since for the Northern Leeward islands, it is evident that the beetle diversity is markedly understudied, and that the actual number of species is many times higher than now known' (Peck 2011, 2016). Wagner et al. (2010) mention in their description of a new species of moth flies associated with bromeliads (plants) that few entomologists have visited Saba. Also Bland \& Desutter (2003) studying crickets note that compared to St. Eustatius, Saba is far less accessible making it very likely that additional Orthoptera species are present in Saba's dense forests. For spiders, a group which may also be understudied in the SSS islands, in recent years new species were found for the neighbouring island of St. Barthélemy (Table 12). This suggests that additional study may yield more endemic species for the SSS islands.

\subsection{Potential endemics}

For the neighbouring islands, 48 species were found that are absent on the SSS islands and Saba Bank (Table 12). Of these plants, reptiles, beetles, spiders and scorpions, potential endemics are more likely to be found within the groups of beetles, spiders and scorpions species than within reptiles or plants. In this analysis we did not fully assess the number of potential endemics present on the neighbouring islands.

\subsection{IUCN Conservation status}

The IUCN provides the most comprehensive list of endangered species worldwide. The conservation status has only been assessed for a very limited number of (widely occurring) species, but not for most endemics. A generally recognised shortcoming of the IUCN Red List is that small, local endemics are strongly under assessed (Leclerc et al. 2018). Many endemics are ecological specialists, and are confined to specific habitats. The conservation status of habitats of Saba and St. Eustatius (which are generally much better-off than those of overpopulated St. Martin) are all assessed as unfavourable, some of which unfavourable-bad (Debrot et al. 2018), it is expected that many more species are threatened than one could conclude from the IUCN Red List. The conservation status for most endemic species occuring on St. Martin is probably worse, due to the devastating impact of hurricane Irma at the end of 2017 (DCNA Nature 2017), resulting in more fragmented habitats and due to much larger numbers of extremely predatory invasive species such as the mongoose, Herpestes auropunctatus, vervet monkey, Clorocebus pygerythrus, and raccoon, Procyon lotor (van Buurt et al. 2012). Joint regional conservation strategies should be devised to spread extinction risk by enhancing or restoring a number of viable populations for each species. One approach used more and more often is that of reintroduction of species to enhance establishment of multiple viable populations in an effort to "spread" extinction risk. Translocation to establish populations at alternative locations is being used successfully in the Caribbean for endemic lizards (Fitzgerald et al. 2015) and birds (McClure et al. 2017), while the IUCN (2013) has even developed guidelines for reintroductions and translocations for conservation purposes.

\subsection{Research priorities and recommendations}

There is an urgent need for research towards:

- $\quad$ Assessments of the conservation status of the endemic taxa (species and subspecies) on the one or few islands they occur (or once occurred) on.

- Development of a conservation strategy to minimize extinction risk of the endemic species. Strategies to consider could include exchange between islands and populations to bolster genetic viability, and the establishment of satellite populations on neighbouring islands, reintroductions or ex situ captive breeding populations (Legouez et al. 2009, Debrot and 
Boman 2013, Debrot et al. 2013, Grant and Hudson 2015) in order to reduce risk of extinction due to local catastrophic events.

To get a better understanding of the biodiveristy of the SSS islands and Saba Bank, it is clear that:

- $\quad$ Specialised biological surveys should be carried out for species groups less studied or for which more endemics are likely to be present. Recent expeditions to the SSS-islands and the Saba Bank have revealed taxa that are new to the region and probably also new to science, with potential endemics among them. Marine and terrestrial expeditions by Naturalis Biodiversity Center in 2015 resulted for instance in at least 80 new species for St. Eustatius, with some possibly even new to science (NatureToday 2015; Hoeksema 2015). Also the NICO-expedition in 2018, among others to the Saba Bank, resulted in the discovery of new taxa for the area (https://nico-expeditie.nl/blogs/nederlandse-diepzee-fauna-haaien-enreuze-pissebedden-op-de-saba-bank). The results were not yet available for this report.

To improve the list of endemics or find new endemics we suggest to:

- Include the currently lacking species groups in a next version of the list.

- Check the literature for new species descriptions, linked to recent reports on undescribed species.

- Study the geographical range of each species in this list in more detail to come up with more precise specifications of the endemic ranges.

- Consult experts in the region by sending material or exchange descriptions of species with those experts.

- Look for opportunities to join regional genetic analysis of species. This allows for obtaining results relatively easily, but requires a good overview of ongoing research by different institutions.

- Get insight in possible number of new species by looking at predictions of species numbers based on species accumulation curves. 


\section{$5 \quad$ Acknowledgements}

In this assignment we had to consult numerous taxonomic specialists. For their help in this initiative we hereby express our sincere gratitude to the following individuals: Sarah Crews of the California Academy of Sciences; Gerard van Buurt from Curaçao; Tello Neckheim from the Netherlands, Sylvia van Leeuwen of the Stichting ANEMOON; Ad Hovestadt from the Netherlands; K.D. Dijkstra and John Smit of the EIS Kenniscentrum; and Harry ten Hove; Charles Fransen; Ronald Vonk; Pepijn Kamminga; Bert Hoeksema; Jeroen Goud; Nicole de Voogd, Rob van Soest; Willem Prud'homme van Reine, all the latter of Naturalis, The Netherlands.

This work was commissioned to Wageningen Marine Research (A.O. Debrot, project leader) by the Ministry of Agriculture, Nature and Food Quality (LNV) for the purposes of the Policy Support Research Theme "Caribbean Netherlands", under project BO-43-021.04-012 (KD-2018-055) and project number 4318100227. We thank policy officers Hayo Haanstra (LNV, The Hague), Ivo van den Boogaard (LNV, The Hague) and Paul Hoetjes (RCN, Kralendijk Bonaire) for their support. 


\section{Quality Assurance}

Wageningen Marine Research utilises an ISO 9001:2008 certified quality management system (certificate number: 187378-2015-AQ-NLD-RvA). This certificate is valid until 15 December 2018. The organisation has been certified since 27 February 2001. The certification was issued by DNV Certification B.V.

If the quality cannot be guaranteed, appropriate measures are taken. 


\section{References}

Axelrod FS (2017) A Systematic Vademecum to the Vascular Plants of Sint Eustatius. BRIT Press. (http://www.dcbd.nl/document/systematic-vademecum-vascular-plants-sint-eustatius).

Bail P (1993) The genus Lyria Gray, 1847. Part II. Xenophora 64:4-19

Bárrios S \& Samuel CA (2015). Rondeletia anguillensis. The IUCN Red List of Threatened Species 2015. http://dx.doi.org/10.2305/IUCN.UK.2015-2.RLTS.T16757145A16757253.en

BEST (2016) Regional ecosystem profile - Caribbean Region. 2016. EU Outermost Regions and Overseas Countries and Territories, Amandine Vaslet \& Romain Renoux. BEST, Service contract 07.0307.2013/666363/SER/B2, European Commission, 261 pp + 5 Appendices (http://ec.europa.eu/environment/nature/biodiversity/best/pdf/bestecosystem profile carribean 2016.pdf).

Biber E (2002). Patterns of endemic extinctions among island bird species. Ecography 25, 661-676.

Bland RG, Desutter-Grandcolas L (2003) An annotated list of Orthoptera from St. Eustatius and Saba, Dutch West Indies, with descriptions of two new cricket species (Trigonidiidae, Mogoplistidae) (https://doi.org/10.1665/1082-6467(2003)012[0115:AALOOF]2.0.CO;2). Journal of Orthoptera Research 12:115-126

Bos OG, Becking LE, Meesters HWG (2016) Saba Bank: Research 2011-2016 (http://edepot.wur.nl/400225). Wageningen Marine Research

Brace S, Turvey ST, Weksler M, Hoogland ML, \& Barnes I (2015). Unexpected evolutionary diversity in a recently extinct Caribbean mammal radiation. Proc. R. Soc. B, 282(1807), 20142371.

Breuil M. (2013). Caractérisation morphologique de I'iguane commun Iguana iguana (Linnaeus, 1758), de l'iguane des Petites Antilles Iguana delicatissima Laurenti, 1768 et de leurs hybrides. Bull. Soc. Herp. Fr, 147, 309-346.

Broome R, Sabir K, Carrington S (2007) "Plants of the Eastern Caribbean". (http://ecflora.cavehill.uwi.edu/index.html)

Buurt G Van \& Debrot AO (2012). Exotic and invasive terrestrial and freshwater animal species in the Dutch Caribbean (http://edepot.wur.nl/192697). IMARES Report number C001/12. 37 pp.

Clark PU, Mix AC (2002) Ice sheets and sea level of the Last Glacial Maximum. Quarterny Science Reviews 21:1-7

Dávalos L \& Rodriguez A (2008). Ardops nichollsi. The IUCN Red List of Threatened Species 2008: e.T2089A9234725. http://dx.doi.org/10.2305/IUCN.UK.2008.RLTS.T2089A9234725.en. Downloaded on 13 August 2018.

Debrot AO (2006) Preliminary checklist of extant and fossil endemic taxa of the ABC-Islands, Leeward Antilles (http://www.dcbd.nl/sites/www.dcbd.nl/files/documents/Debrot\%25202006\%2520Endemic\%2520 species\%2520checklist\%2520Leewards.pdf). CARMABI Foundation, Curaçao.

Debrot AO and Boman E (2013). The Lesser Antillean Iguana on St. Eustatius: 2012 status update and review of limiting factors (http://library.wur.nl/WebQuery/wurpubs/fulltext/248624). IMARES Report C166/12, 45 pp.

Debrot AO, Boman EB, Madden H (2013). The Lesser Antillean Iguana on St. Eustatius: a 2012 population status update and causes for concern (http://edepot.wur.nl/264502). Reptiles \& Amphibians (IRCS) 20: 44-52.

Debrot AO, van Buurt G, Caballero A, Antczak AA (2006) A historical review of records of the West Indian manatee and the American crocodile in the Dutch Antilles. Caribb J Sci 42:272-280 (http://www.dcbd.nl/document/historical-review-records-west-indian-manatee-and-americancrocodile-dutch-antilles).

Debrot D, Langley J, Vermeij M, Slijkerman D, Jongbloed R, Van Beek I, de Freitas J, Pors L, Jak R, Rockmann C, Cremer JSM (2018) Description of the Outstanding Universal Value (OUV) of the Proposed Marine Nomination Properties of the Bonaire and Curaçao Marine Parks (BCMP). Wageningen Marine Research (University \& Research Centre). Report C003/18.

del Hoyo J, Collar NJ (2014) HBW and Birdlife International Illustrated Checklist of the Birds of the World. Volume 1: Non-passerines. Lynx Edicions, Barcelona. 
del Hoyo J, Collar NJ (2016) HBW and Birdlife International Illustrated Checklist of the Birds of the World. Volume 2: Passerines. Lynx Edicions, Barcelona.

Du Bois-Reymond Marcus E \& Marcus E (1968) Polycladida from Curaçao and faunistically related regions (http://www.repository.naturalis.nl/document/549857). Studies on the Fauna of Curaçao and other Caribbean Islands 26:1-133

Etnoyer PJ, Wirsching HH, Sanchez JA (2010) Rapid Assessment of Octocoral Diversity and Habitat on Saba Bank, Netherlands Antilles (https://doi.org/10.1371/journal.pone.0010668). PLOS one 5:1-9

Fiers F (1986) Harpacticoid copepods from the West Indian Islands: Darcythompsoniidae (Copepoda, Harpacticoida). Bijdragen tot de Dierkunde 56:282-290. (http://www.repository.naturalis.nl/document/548068).

Fitzgerald LA, Treglia ML, Angeli N, Hibbitts TJ, Leavitt DJ, Subalusky AL, ... \& Hillis-Starr Z (2015). Determinants of successful establishment and post-translocation dispersal of a new population of the critically endangered St. Croix ground lizard (Ameiva polops). Restoration Ecology, 23(6), 776786.

Froese R, Pauly D (2018) FishBase. World Wide Web electronic publication. Www.fishbase.org, version (02/2018).

Gascuel F, Laroche F, Bonnet-Lebrun AS \& Rodrigues AS (2016). The effects of archipelago spatial structure on island diversity and endemism: predictions from a spatially-structured neutral model. Evolution, 70(11), 2657-2666.

Glasby CJ (1999). The Namanereidinae (Polychaeta: Nereididae). Part 1. Taxonomy and phylogeny. Records of the Australian Museum, Supplement. 25: 1-129. (http://dx.doi.org/10.3853/j.08127387.25.1999.1354)

Grant TD \& Hudson RD (2015). West Indian iguana Cyclura spp reintroduction and recovery programmes: zoo support and involvement. International zoo yearbook, 49(1), 49-55 (https://zslpublications.onlinelibrary.wiley.com/doi/full/10.1111/izy.12078).

Hedges B, Powell R \& Daltry JC (2017). Spondylurus powelli. The IUCN Red List of Threatened Species 2017: e.T47103288A72240413. (http://dx.doi.org/10.2305/IUCN.UK.2017-

2.RLTS.T47103288A72240413.en.) Downloaded on 30 August 2018.

Heupel MR (2009). Galeus antillensis. The IUCN Red List of Threatened Species 2009:

(http://www.iucnredlist.org/details/161732/0) Downloaded on 13 August 2018.

Hill (2012) Butterflies and moths in the West Indies of the Caribbean. Focus on Nature Tours.

Hoeksema BW (2015). Statia Marine Expedition. BioNews 19:5(https://www.researchgate.net/profile/Bert_Hoeksema/publication/284178993_Statia_Marine _Expedition/links/564e3cfc08ae1ef9296c6f76/Statia-Marine-

Expedition.pdf?origin=publication_detail)

Horwith B, Lindsay K (1999) A biodiversity profile of St. Kitts and Nevis (http://www.globalislands.net/userfiles/nevis 2.pdf). Island Resources Foundation, Eastern Caribbean Biodiversity Programme.

IUCN/SSC (2013). Guidelines for Reintroductions and Other Conservation Translocations. Version 1.0. Gland, Switzerland: IUCN Species Survival Commission, viiii +57 pp.

Kormilev N, Van Doesburg P (1986) Notes on Phymatidae (Heteroptera) (http://www.repository.naturalis.nl/document/149585). Zoologische Mededelingen uitgegeven door het Rijksmuseum van Natuurlijke Historie te Leiden (Ministerie Van Welzijn , Volksgezondheid En Cultuur) 60:113-127.

Kouvari M \& van der Geer AA (2018). Biogeography of extinction: The demise of insular mammals from the Late Pleistocene till today. Palaeogeography, Palaeoclimatology, Palaeoecology 505: 295304(https://doi.org/10.1016/j.palaeo.2018.06.008).

Krings A, Axelrod FS (2013) Gonolobus aloiensis (Apocynaceae, Asclepiadoideae), a New Species from St. Eustatius. Systematic Botany 38:1132-1137

Kyne PM, Carlson JK, Ebert DA, Fordham SV, Bizzarro JJ, Graham RT, Kulka DW, Tewes EE, Harrison LR, Dulvy NK (eds) (2012) The Conservation Status of North American, Central American, and Caribbean Chondrichthyans (https://portals.iucn.org/library/sites/library/files/documents/2012046.pdf). IUCN Species Survival Commission Shark Specialist Group Vancouver, Canada

Leclerc C, Courchamp F \& Bellard C (2018). Insular threat associations within taxa worldwide. Scientific reports, 8(1), 6393 (https://www.nature.com/articles/s41598-018-24733-0).

Leeuwen SJ, Hovestadt A, de Winter T (2016) A new species of Glyphyalus (Gastropoda, Pulmonata, Oxychilidae) from the Dutch Caribbean island of St. Eustatius. Basteria 80:39-46 
Legouez C, Maillard J-F, Arenales Del Campo V, and M Breuil (2009). L'iguane des Petites Antilles: une espèce menacée en Martinique: premières mesures de conservation. Faune Sauvage 284: 60-65 (http://www.oncfs.gouv.fr/IMG/file/outre-mer/fs284_legouez.pdf).

Littler MM, Littler DS, Brooks BL (2010) Marine Macroalgal Diversity Assessment of Saba Bank, Netherlands Antilles (https://doi.org/10.1371/journal.pone.0010677). PLOS one 5:e10677, 10671-10611

Lomolino MV, Riddle BR, Whittaker RJ (2017). Biogeography: Biological Diversity Across Space and Time, 5th ed. Sinauer Associates, Sunderland, Massachusetts.

Maier CA \& Ivie MA (2013). New Species and Records of Chrysobothris Eschscholtz (Coleoptera: Buprestidae) from Montserrat, Saba, and Anguilla, with a Key to the Chrysobothris thoracica Species-Group in the West Indies. The Coleopterists Bulletin 67(2):81-88. 2013 (https://doi.org/10.1649/0010-065X-67.2.81)

McClure CJ, Rolek BW, Hayes TI, Hayes CD, Thorstrom R, Curti M, \& Anderson DL (2017). Successful enhancement of Ridgway's Hawk populations through recruitment of translocated birds. The Condor, 119(4), 855-864

McFarlane DA, Lundberg J, Maincent G (2014) New specimens of Amblyrhiza inundata (Rodentia: Caviomorpha) from the Middle Pleistocene of Saint Barthélemy, French West Indies (http://caribjes.com/CJESpdf/CJES47-03-Macfarlane-rodent.pdf). Caribbean Journal of Earth Science 47:15-19

Min EZ (2013) Nature Policy Plan Caribbean Netherlands. Nature Policy for the Caribbean Netherlands 2013-2017 (http://www.denanature.org/wpcontent/uploads/2013/10/EZ BO NaturePolicyPlan\%20Car.NL ENG 2.pdf).

Min EZ (2013) Natuurbeleidsplan Caribisch Nederland. Natuurbeleid voor Caribisch Nederland 20132017 https://www.rijksoverheid.nl/documenten/rapporten/2013/04/24/natuurbeleidsplancaribisch-nederland-2013-2017).

Myers N, Mittermeier RA, Mittermeier CG, da Fonseca GAB, Kent J (2000) Biodiversity hotspots for conservation priorities (https://www.nature.com/articles/35002501). Nature 403:853

Naturalis Biodiversity Center (2017). Dutch Caribbean Species Register, www.dutchcaribbeanspecies.org. Accessed on 24/07/2018.

Neckheim CM, Hovestadt A (2016) Land- en zoetwatermollusken verzameld op Sint Maarten (Nederlandse Antillen) en St. Martin. Spirula 409:18-24

Otte D, Perez-Gelabert D (2009) Caribbean Crickets The Orthopterists' Society. 792 pp.

Peck SB (2011) The diversity and distributions of the beetles (Insecta: Coleoptera) of the northern Leeward Islands, Lesser Antilles (Anguilla, Antigua, Barbuda, Nevis, Saba, St. Barthélemy, St. Eustatius, St. Kitts, and St. Martin-St. Maarten (http://digitalcommons.unl.edu/cgi/viewcontent.cgi?article $=1677 \&$ context=insectamundi). Insecta Mundi 0159:1-54

Peck SB (2016) The beetles of the Lesser Antilles (Insecta, Coleoptera): diversity and distributions (http://digitalcommons.unl.edu/cgi/viewcontent.cgi?article=1967\&context=insectamundi). Insecta Mundi 0460:1-360

Powell R, Henderson RW (2005) Conservation Status of Lesser Antillean Reptiles (https://www.researchgate.net/profile/Robert_Henderson6/publication/264838520_Conservation_ Status_of_Lesser_Antillean_Reptiles/links/540ee70e0cf2f2b29a3c3f28.pdf). Iguana 12:62-77

Powell R, Henderson RW, Parmerlee JSJ (2015) The Reptiles and Amphibians of the Dutch Caribbean: St. Eustatius, Saba, and St. Maarten. Second Edition, revised and expanded. Nature Guides Series No. 004. Dutch Caribbean Nature Alliance, Bonaire, Dutch Caribbean

Procter D, Fleming LV (eds) (1999) Biodiversity: the UK Overseas Territories. Compiled by S. Oldfield. (http://www.widecast.org/What/Country/Anguilla/Docs/Procter and Fleming \%281999\%29 UKO T Biodiversity.pdf). JNCC, Peterborough

Rojer A (1997a) Biological Inventory of St. Maarten. (http://www.dcbd.nl/document/biologicalinventory-st-maarten). Stichting Carmabi.

Rojer A (1997b) Biological Inventory of Saba (http://www.dcbd.nl/document/biological-inventorysaba). Stichting Carmabi

Rojer A (1997c) Biological Inventory of St. Eustatius (https://pdfs.semanticscholar.org/b28d/1bc97ccbf1b0f2134b2462877d82c21fdfbc.pdf). Stichting Carmabi. 
Stephen, CL, Reynoso, VH, Collett, WS, Hasbun, CR, \& Breinholt, JW (2013). Geographical structure and cryptic lineages within common green iguanas, Iguana iguana. Journal of Biogeography, 40(1), 50-62 (https://doi.org/10.1111/j.1365-2699.2012.02780.x).

Taylor OD, Glover EA (2016) Lucinid bivalves of Guadeloupe: diversity and systematics in the context of the tropical Western Atlantic (Mollusca: Bivalvia: Lucinidae) (http://dx.doi.org/10.11646/zootaxa.4196.3.1). Zootaxa 4196:zootaxa.4196.4193.4191

Teruel R (2008) A new species of Oiclus Simon 1880 (Scorpiones: Scorpionidae: Diplocentrinae) from Saint-Barthélemy, Lesser Antilles (http://seaentomologia.org/Publicaciones/PDF/BOLN43/095 099 BSEA 43 Oiclus questeli.pdf). Boletín Sociedad Entomológica Aragonesa 43:95-99

Teruel R, Questel K (2011a) A new species of Ammotrechella roewer 1934 (Solifugae: Ammotrechidae) from Saint-Barthélemy, Lesser Antilles. Boletín de la Sociedad Entomológica Aragonesa (SEA) (http://sea-entomologiaorg/PDF/BSEA49ARACNO/B49083pdf) 49:83-86

Teruel R, Questel K (2011b) A new species of Charinus Simon 1892 (Amblypygi: Charinidae) from the Leeward Islands, Lesser Antilles (http://sea-entomologia.org/PDF/BSEA49ARACNO/B49015.pdf). Boletín de la Sociedad Entomológica Aragonesa (SEA) (http://seaentomologiaorg/PDF/BSEA49ARACNO/B49083pdf) 49:15-18

Van den Burg M, Breuil M \& Knapp C (2018). Iguana delicatissima. The IUCN Red List of Threatened Species 2018: e.T10800A122936983. (http://dx.doi.org/10.2305/IUCN.UK.20181.RLTS.T10800A122936983.en.). Downloaded on 03 September 2018.

Van den Tooren D (2008) New Neotropical pseudoscorpions (Pseudoscorpiones) from Aruba, Trinidad and Saba (Lesser Antilles), with some new localities of pseudoscoprions from Aruba and Bonaire. Zoologische Mededelingen 82:423-440

Vroman M (1967) A new species of Stichothamnion (Rhodophyta) from the West Indies (http://natuurtijdschriften.nl/download?type=document\&docid=539436). Acta Botanica Neerlandica 15:557-561

Wagner R, Richardson BA, Richardson MJ (2010) A new psychodid species from Saban tank bromeliads (https://doi.org/10.1080/01650521.2010.514800). Studies on Neotropical Fauna and Environment 45:121-127

Williams JT, Carpenter KE, Van Tassell JL, Hoetjes P, Toller W, Etnoyer P, Smith M (2010) Biodiversity Assessment of the Fishes of Saba Bank Atoll, Netherlands Antilles (http://journals.plos.org/plosone/article?id=10.1371/journal.pone.0010676). PLOS ONE 5:e10676

Wilting M, Meesters HWG, De Voogd N, Bos OG, Becking LE (in prep) Sponge diversity of Saba Bank.

World Spider Catalog (2018) World Spider Catalog. Version 19.0. Natural History Museum Bern, online at http://wsc.nmbe.ch, accessed on 01-06-2018. doi: 10.24436/2.

WoRMS Editorial Board (2018). World Register of Marine Species. Available from http://www.marinespecies.org at VLIZ. Accessed 2018-05-01. doi:10.14284/170

Yokoyama M (2013) The Incomplete guide to the wildlife of Saint Martin. Revised and expanded second edition. SXM Wildlife. 131p. 


\section{Justification}

Report: C067/18

Project Number: 4318100227

The scientific quality of this report has been peer reviewed by a colleague scientist and a member of the Management Team of Wageningen Marine Research

Approved: $\quad$ dr. M. van der Geest

researcher

Signature:

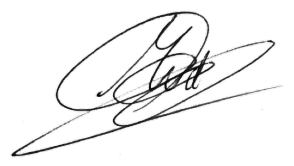

Date:

19-09-2018

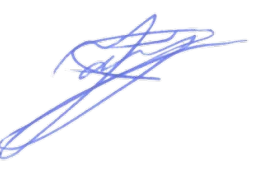

Approved: J. Asjes

Manager integration 


\section{Annex 1: Numbers of endemics of SSS islands and Saba Bank}


Table 14. Total number of animal and plant species for St. Martin, St. Eustatius, Saba and Saba Bank together ('SSS or Saba Bank') and separate, as well as the number of endemics per endemic level with subtotals.

\begin{tabular}{|c|c|c|c|c|c|c|c|c|c|c|c|}
\hline Species group & 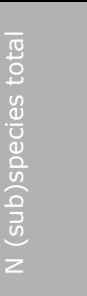 & 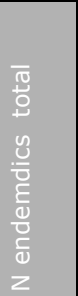 & 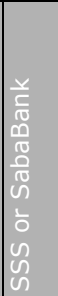 & 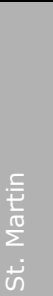 & 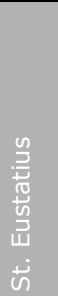 & $\frac{\pi}{80}$ & $\begin{array}{l}\frac{y}{\frac{1}{10}} \\
10 \\
0 \\
10 \\
0 \\
0 \\
0\end{array}$ & 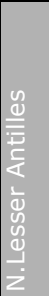 & 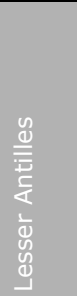 & $\mid \frac{y}{\frac{y}{2}}$ & 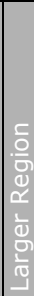 \\
\hline Animalia & 2661 & 198 & 31 & 10 & 8 & 10 & 3 & 11 & 100 & 54 & 3 \\
\hline Annelida & 35 & 1 & 1 & - & 1 & - & - & - & - & - & - \\
\hline Hirudinea & 1 & - & - & - & - & - & - & - & - & - & - \\
\hline Rhynchobdellida & 1 & - & - & - & - & - & - & - & - & - & - \\
\hline Oligochaeta & 8 & - & - & - & - & - & - & - & - & - & - \\
\hline Haplotaxida & 3 & - & - & - & - & - & - & - & - & - & - \\
\hline Opisthophora & 2 & - & - & - & - & - & - & - & - & - & - \\
\hline Tubificida & 3 & - & - & - & - & - & - & - & - & - & - \\
\hline Polychaeta & 26 & 1 & 1 & - & 1 & - & - & - & - & - & - \\
\hline Amphinomida & 1 & - & - & - & - & - & - & - & - & - & - \\
\hline Eunicida & 1 & - & - & - & - & - & - & - & - & - & - \\
\hline Phyllodocida & 8 & 1 & 1 & - & 1 & - & - & - & - & - & - \\
\hline Sabellida & 14 & - & - & - & - & - & - & - & - & - & - \\
\hline Scolecida & 1 & - & - & - & - & - & - & - & - & - & - \\
\hline Terebellida & 1 & - & - & - & - & - & - & - & - & - & - \\
\hline Arthropoda & 874 & 108 & 21 & 6 & 6 & 9 & - & 6 & 41 & 38 & 3 \\
\hline Arachnida & 127 & 23 & 4 & 1 & 1 & 2 & - & 2 & 5 & 12 & - \\
\hline Amblypygi & 1 & 1 & - & - & - & - & - & - & - & 1 & - \\
\hline Araneae & 83 & 17 & 1 & - & - & 1 & - & 2 & 3 & 11 & - \\
\hline Ixodida & 5 & - & - & - & - & - & - & - & - & - & - \\
\hline Pseudoscorpiones & 5 & 3 & 3 & 1 & 1 & 1 & - & - & - & - & - \\
\hline Sarcoptiformes & 30 & - & - & - & - & - & - & - & - & - & - \\
\hline Scorpiones & 3 & 2 & - & - & - & - & - & - & 2 & - & - \\
\hline Branchiopoda & 1 & - & - & - & - & - & - & - & - & - & - \\
\hline Anostraca & 1 & - & - & - & - & - & - & - & - & - & - \\
\hline Chilopoda & 2 & - & - & - & - & - & - & - & - & - & - \\
\hline Scolopendromorpha & 2 & - & - & - & - & - & - & - & - & - & - \\
\hline Diplopoda & 13 & - & - & - & - & - & - & - & - & - & - \\
\hline Polydesmida & 6 & - & - & - & - & - & - & - & - & - & - \\
\hline Polyxenida & 2 & - & - & - & - & - & - & - & - & - & - \\
\hline Polyzoniida & 1 & - & - & - & - & - & - & - & - & - & - \\
\hline Spirobolida & 4 & - & - & - & - & - & - & - & - & - & - \\
\hline Hexanauplia & 13 & 2 & 2 & 2 & - & - & - & - & - & - & - \\
\hline Harpacticoida & 1 & 1 & 1 & 1 & - & - & - & - & - & - & - \\
\hline Lepadiformes & 1 & - & - & - & - & - & - & - & - & - & - \\
\hline Poecilostomatoida & 5 & 1 & 1 & 1 & - & - & - & - & - & - & - \\
\hline Sessilia & 5 & - & - & - & - & - & - & - & - & - & - \\
\hline Siphonostomatoida & 1 & - & - & - & - & - & - & - & - & - & - \\
\hline Insecta & 467 & 78 & 15 & 3 & 5 & 7 & - & 4 & 31 & 26 & 3 \\
\hline Blattodea & 5 & - & - & - & - & - & - & - & - & - & - \\
\hline Coleoptera & 122 & 33 & 3 & 2 & - & 1 & - & - & 16 & 14 & - \\
\hline Dermaptera & 4 & - & - & - & - & - & - & - & - & - & - \\
\hline Diptera & 25 & 4 & 1 & - & - & 1 & - & - & 1 & 2 & - \\
\hline Hemiptera & 64 & 3 & 1 & - & - & 1 & - & - & 1 & - & 1 \\
\hline Hymenoptera & 74 & 3 & - & - & - & - & - & 1 & - & 1 & 1 \\
\hline Lepidoptera & 129 & 12 & - & - & - & - & - & 2 & 7 & 4 & - \\
\hline Neuroptera & 3 & - & - & - & - & - & - & - & - & - & - \\
\hline Odonata & 8 & 1 & - & - & - & - & - & - & 1 & - & - \\
\hline Orthoptera & 32 & 22 & 10 & 1 & 5 & 4 & - & 1 & 5 & 5 & 1 \\
\hline Zygentoma & 1 & - & - & - & - & - & - & - & - & - & - \\
\hline Malacostraca & 242 & 4 & - & - & - & - & - & - & 4 & - & - \\
\hline Amphipoda & 2 & 1 & - & - & - & - & - & - & 1 & - & - \\
\hline Decapoda & 227 & 1 & - & - & - & - & - & - & 1 & - & - \\
\hline Isopoda & 7 & 2 & - & - & - & - & - & - & 2 & - & - \\
\hline Mysida & 4 & - & - & - & - & - & - & - & - & - & - \\
\hline Stomatopoda & 2 & - & - & - & - & - & - & - & - & - & - \\
\hline Ostracoda & 3 & - & - & - & - & - & - & - & - & - & - \\
\hline Podocopida & 3 & - & - & - & - & - & - & - & - & - & - \\
\hline Pycnogonida & 6 & 1 & - & - & - & - & - & - & 1 & - & - \\
\hline Pantopoda & 6 & 1 & - & - & - & - & - & - & 1 & - & - \\
\hline Brachiopoda & 8 & - & - & - & - & - & - & - & - & - & - \\
\hline Rhynchonellata & 8 & - & - & - & - & - & - & - & - & - & - \\
\hline Rhynchonellida & 1 & - & - & - & - & - & - & - & - & - & - \\
\hline Terebratulida & 6 & - & - & - & - & - & - & - & - & - & - \\
\hline Thecideida & 1 & - & - & - & - & - & - & - & - & - & - \\
\hline Chordata & 769 & 50 & 5 & 3 & - & 1 & 1 & 4 & 31 & 9 & - \\
\hline Actinopterygii & 420 & 4 & 2 & 1 & - & - & 1 & - & 1 & 1 & - \\
\hline
\end{tabular}




\begin{tabular}{|c|c|c|c|c|c|c|c|c|c|c|}
\hline Albuliformes & 1 & -1 & - & - & - & $-\quad-1$ & - & - & -1 & - \\
\hline Anguilliformes & 27 & - & - & - & - & $-\quad-1$ & - & - & - & - \\
\hline Atheriniformes & 3 & 1 & 1 & 1 & - & $-\quad-$ & - & - & - & - \\
\hline Aulopiformes & 10 & - & - & - & - & $-\quad-1$ & - & - & - & - \\
\hline Beloniformes & 7 & - & - & - & - & $-\quad-1$ & - & - & - & - \\
\hline Beryciformes & 9 & - & - & - & - & $-\quad-1$ & - & - & - & - \\
\hline Clupeiformes & 7 & - & - & - & - & $-\quad-$ & - & - & - & - \\
\hline Cyprinodontiformes & 3 & - & - & - & - & $-\quad-1$ & - & - & - & - \\
\hline Elopiformes & 1 & - & - & - & - & $-\quad-1$ & - & - & - & - \\
\hline Gadiformes & 8 & - & - & - & - & $-\quad-$ & - & - & - & - \\
\hline Gobiesociformes & 2 & - & - & - & - & $-\quad-$ & - & - & - & - \\
\hline Lophiiformes & 9 & - & - & - & - & $-\quad-1$ & - & - & - & - \\
\hline Notacanthiformes & 1 & - & - & - & - & $-\quad-1$ & - & - & - & - \\
\hline Ophidiiformes & 9 & - & - & - & - & $-\quad-1$ & - & - & - & - \\
\hline Osmeriformes & 1 & - & - & - & - & & - & - & - & - \\
\hline Perciformes & 260 & 3 & 1 & - & - & -1 & - & 1 & 1 & - \\
\hline Pleuronectiformes & 10 & - & - & - & - & $-\quad-$ & - & - & - & - \\
\hline Polymixiiformes & 1 & - & - & - & - & $-\quad-$ & - & - & - & - \\
\hline Scorpaeniformes & 14 & - & - & - & - & $-\quad-1$ & - & - & - & - \\
\hline Syngnathiformes & 9 & - & - & - & - & $-\quad-1$ & - & - & - & - \\
\hline Tetraodontiformes & 26 & - & - & - & - & $-\quad-$ & - & - & - & - \\
\hline Zeiformes & 2 & - & - & - & - & & - & - & - & - \\
\hline Amphibia & 4 & 1 & - & - & - & $-\quad-1$ & - & 1 & - & - \\
\hline Anura & 4 & 1 & - & - & - & $-\quad-1$ & - & 1 & - & - \\
\hline Ascidiacea & 20 & - & - & - & - & $-\quad-$ & - & - & - & - \\
\hline Aplousobranchia & 10 & - & - & - & - & $-\quad-1$ & - & - & - & - \\
\hline Phlebobranchia & 4 & - & - & - & - & $-\quad-1$ & - & - & - & - \\
\hline Stolidobranchia & 6 & - & - & - & - & $-\quad-$ & - & - & - & - \\
\hline Aves & 232 & 23 & - & - & - & $-\quad-$ & 2 & 15 & 6 & - \\
\hline Accipitriformes & 4 & - & - & - & - & $-\quad-1$ & - & - & - & - \\
\hline Anseriformes & 18 & - & - & - & - & $-\quad-1$ & - & - & - & - \\
\hline Apodiformes & 6 & 4 & - & - & - & $-\quad-$ & - & 2 & 2 & - \\
\hline Caprimulgiformes & 2 & - & - & - & - & $-\quad-1$ & - & - & -1 & - \\
\hline Charadriiformes & 60 & - & - & - & - & $-\quad-1$ & - & - & -1 & - \\
\hline Columbiformes & 13 & 3 & - & - & - & $-\quad-1$ & - & 2 & 1 & - \\
\hline Coraciiformes & 1 & - & - & - & - & $-\quad-$ & - & - & - & - \\
\hline Cuculiformes & 3 & - & - & - & - & $-\quad-1$ & - & - & - & - \\
\hline Falconiformes & 5 & 1 & - & - & - & $-\quad-1$ & - & - & 1 & - \\
\hline Galliformes & 2 & - & - & - & - & $-\quad-1$ & - & - & - & - \\
\hline Gruiformes & 7 & - & - & - & - & $-\quad-$ & - & - & - & - \\
\hline Passeriformes & 70 & 14 & - & - & - & $-\quad-1$ & 2 & 11 & 1 & - \\
\hline Pelecaniformes & 21 & - & - & - & - & $-\quad-1$ & - & - & - & - \\
\hline Phaethontiformes & 4 & - & - & - & - & $-\quad-1$ & - & - & - & - \\
\hline Phoenicopteriformes & 1 & - & - & - & - & $-\quad-1$ & - & - & - & - \\
\hline Piciformes & 1 & - & - & - & - & $-\quad-1$ & - & - & - & - \\
\hline Podicipediformes & 3 & 1 & - & - & - & $-\quad-1$ & - & - & 1 & - \\
\hline Procellariiformes & 3 & - & - & - & - & $-\quad-$ & - & - & - & - \\
\hline Psittaciformes & 2 & - & - & - & - & $-\quad-$ & - & - & - & - \\
\hline Suliformes & 6 & - & - & - & - & $-\quad-1$ & - & - & -1 & - \\
\hline Chondrichthyes & 24 & 1 & - & - & - & $-\quad-1$ & - & - & 1 & - \\
\hline Carcharhiniformes & 10 & 1 & - & - & - & $-\quad-1$ & - & - & 1 & - \\
\hline Hexanchiformes (Frill and Cow Sharks) & 1 & - & - & - & - & $-\quad-1$ & - & - & - & - \\
\hline Myliobatiformes & 3 & - & - & - & - & $-\quad-$ & - & - & - & - \\
\hline Orectolobiformes & 2 & - & - & - & - & $-\quad-$ & - & - & - & - \\
\hline Rajiformes & 1 & - & - & - & - & $-\quad-1$ & - & - & - & - \\
\hline Squaliformes & 6 & - & - & - & - & $-\quad-1$ & - & - & - & - \\
\hline Torpediniformes & 1 & - & - & - & - & $-\quad-1$ & - & - & - & - \\
\hline Holocephali & 2 & - & - & - & - & $-\quad-$ & - & - & - & - \\
\hline Chimaeriformes & 2 & - & - & - & - & $-\quad-1$ & - & - & - & - \\
\hline Mammalia & 30 & 5 & - & - & - & $-\quad-1$ & - & 4 & 1 & - \\
\hline Artiodactyla & 4 & - & - & - & - & $-\quad-$ & - & - & - & - \\
\hline Carnivoria & 4 & - & - & - & - & $-\quad-$ & - & - & - & - \\
\hline Cetartiodactyla & 6 & - & - & - & - & $-\quad-1$ & - & - & - & - \\
\hline Chiroptera & 11 & 5 & - & - & - & $-\quad-1$ & - & 4 & 1 & - \\
\hline Perissodactyla & 1 & - & - & - & - & $-\quad-$ & - & - & - & - \\
\hline Primates & 1 & -1 & - & - & - & $-\quad-1$ & - & - & -1 & - \\
\hline Rodentia & 3 & - & - & - & - & $-\quad-1$ & - & - & - & - \\
\hline Reptilia & 36 & 16 & 3 & 2 & - & $1-$ & 3 & 10 & - & - \\
\hline Squamata & 31 & 16 & 3 & 2 & - & $1-$ & 3 & 10 & - & - \\
\hline Testudines Linnaeus, 1758 & 7 & - & - & - & - & $-\quad-1$ & - & - & - & - \\
\hline Cnidaria & 159 & 5 & - & - & - & & - & 1 & 4 & - \\
\hline Anthozoa & 134 & 4 & - & - & - & $-\quad-$ & - & 1 & 3 & - \\
\hline Actiniaria & 8 & - & - & - & - & $-\quad-1$ & - & - & - & - \\
\hline Alyconacea & 48 & 2 & - & - & - & $-\quad-1$ & - & 1 & 1 & - \\
\hline Corallimorpharia & 5 & - & - & - & - & $-\quad-1$ & - & - & - & - \\
\hline Pennatulacea & 1 & - & - & - & - & $-\quad-$ & - & - & - & - \\
\hline Scleractinia & 59 & - & - & - & - & $-\quad-1$ & - & - & - & - \\
\hline Zoantharia & 13 & 2 & - & - & - & $-\quad-1$ & - & - & 2 & - \\
\hline Hydrozoa & 23 & 1 & - & - & - & $-\quad-1$ & - & - & 1 & - \\
\hline Anthoathecata & 9 & 1 & - & - & - & $-\quad-$ & - & - & 1 & - \\
\hline Leptothecata & 14 & - & - & - & - & $-\quad-$ & - & - & - & - \\
\hline Scyphozoa & 2 & - & - & - & - & $-\quad-1$ & - & - & - & - \\
\hline Rhizostomeae & 2 & - & - & - & - & $-\quad-1$ & - & - & - & - \\
\hline
\end{tabular}




\begin{tabular}{|c|c|c|c|c|c|c|c|c|c|c|}
\hline Echinodermata & 17 & - & - & - & - & -- & - & - & - & - \\
\hline Asteroidea & 2 & - & - & - & - & $-\quad-$ & - & - & - & - \\
\hline Valvatida & 2 & - & - & - & - & - & 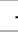 & - & - & - \\
\hline Echinoidea & 5 & - & - & - & - & $-\quad-$ & - & - & - & - \\
\hline Camarodonta & 1 & - & - & - & - & -- & . & - & - & - \\
\hline Cidaroida & 1 & - & - & - & - & - & 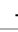 & - & - & - \\
\hline Spatangoida & 3 & - & - & - & - & - & 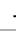 & - & - & - \\
\hline Ophiuroidea & 10 & - & - & - & - & -- & . & - & - & - \\
\hline Ophiurida & 10 & - & - & - & - & - & 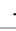 & - & - & - \\
\hline Mollusca & 667 & 33 & 4 & 1 & 1 & -2 & & 26 & 3 & - \\
\hline Bivalvia & 135 & 5 & 1 & - & - & -1 & 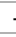 & 3 & 1 & - \\
\hline Anomalodesmata & 14 & 2 & 1 & - & - & -1 & - & 1 & - & - \\
\hline Arcida & 15 & - & - & - & - & $-\quad-$ & - & - & - & - \\
\hline Cardiida & 29 & - & - & - & - & $-\quad-$ & - & - & - & - \\
\hline Carditida & 1 & - & - & - & - & $-\quad-$ & 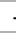 & - & - & - \\
\hline Imparidentia [unassigned] & 10 & - & - & - & - & $-\quad-$ & - & - & - & - \\
\hline Limida & 5 & - & - & - & - & - & 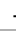 & - & - & - \\
\hline Lucinida & 12 & 2 & - & - & - & $-\quad-$ & 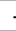 & 1 & 1 & - \\
\hline Mytilida & 4 & - & - & - & - & - & 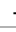 & - & - & - \\
\hline Nuculida & 1 & - & - & - & - & - & 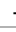 & - & - & - \\
\hline Ostreida & 12 & - & - & - & - & - & 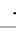 & - & - & - \\
\hline Pectinida & 19 & - & - & - & - & $-\quad-$ & . & - & - & - \\
\hline Venerida & 13 & 1 & - & - & - & $-\quad-$ & 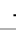 & 1 & - & - \\
\hline Cephalopoda & 5 & - & - & - & - & $-\quad-$ & 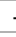 & - & - & - \\
\hline Myopsida & 1 & - & - & - & - & - & 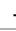 & - & - & - \\
\hline Octopoda & 3 & - & - & - & - & $-\quad-$ & . & - & - & - \\
\hline Spirulida & 1 & - & - & - & - & - & - & - & - & - \\
\hline Gastropoda & 507 & 28 & 3 & 1 & 1 & -1 & re & 23 & 2 & - \\
\hline [unassigned] Caenogastropoda & 40 & - & - & - & - & $-\quad-$ & r. & - & - & - \\
\hline [unassigned] Heterobranchia & 13 & - & - & - & - & $-\quad-$ & re & - & - & - \\
\hline Anaspidea & 5 & - & - & - & - & $-\quad-$ & - & - & - & - \\
\hline Architaenioglossa & 1 & - & - & - & - & $-\quad-$ & r. & - & - & - \\
\hline Cephalaspidea & 17 & - & - & - & - & - & re & - & - & - \\
\hline Cycloneritimorpha & 10 & 3 & - & - & - & $-\quad-$ & re & 3 & - & - \\
\hline Eupulmonata & 7 & - & - & - & - & - & 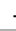 & - & - & - \\
\hline Hygrophila & 7 & - & - & - & - & -- & 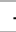 & - & - & - \\
\hline Littorinimorpha & 116 & 4 & - & - & - & $-\quad-$ & 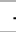 & 4 & - & - \\
\hline NA & 60 & - & - & - & - & - & 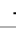 & - & - & - \\
\hline Neogastropoda & 144 & 7 & 2 & 1 & - & -1 & 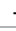 & 5 & - & - \\
\hline Nudibranchia & 20 & - & - & - & - & $-\quad-$ & - & - & - & - \\
\hline Runcinacea & 1 & - & - & - & - & $-\quad-$ & . & - & - & - \\
\hline Sacoglossa & 5 & - & - & - & - & - & . & - & - & - \\
\hline Stylommatophora & 57 & 14 & 1 & - & 1 & - & . & 11 & 2 & - \\
\hline Systellomatophora & 1 & - & - & - & - & - & r. & - & - & - \\
\hline Thecosomata & 3 & - & - & - & - & - & 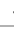 & - & - & - \\
\hline Polyplacophora & 15 & - & - & - & - & $-\quad-$ & r. & - & - & - \\
\hline Chitonida & 15 & - & - & - & - & $-\quad-$ & r. & - & - & - \\
\hline Scaphopoda & 5 & - & - & - & - & $-\quad-$ & r. & - & - & - \\
\hline Dentaliida & 4 & - & - & - & - & $-\quad-$ & r. & - & - & - \\
\hline Gadilida & 1 & - & - & - & - & $-\quad-$ & r. & - & - & - \\
\hline Platyhelminthes & 5 & 1 & - & - & - & $-\quad-$ & . & 1 & - & - \\
\hline Rhabditophora & 5 & 1 & - & - & - & - & re & 1 & - & - \\
\hline Polycladida & 3 & 1 & - & - & - & - & re & 1 & - & - \\
\hline Tricladida & 2 & - & - & - & - & -- & . & - & - & - \\
\hline Porifera & 107 & - & - & - & - & -- & . & - & - & - \\
\hline Calcarea & 2 & - & - & - & - & $-\quad-$ & . & - & - & - \\
\hline Clathrinida & 2 & - & - & - & - & $-\quad-$ & 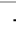 & - & - & - \\
\hline Demospongiae & 102 & - & - & - & - & $-\quad-$ & - & - & - & - \\
\hline Agelasida & 10 & - & - & - & - & $-\quad-$ & 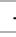 & - & - & - \\
\hline Axinellida & 8 & - & - & - & - & $-\quad-$ & . & - & - & - \\
\hline Biemnida & 1 & - & - & - & - & $-\quad-$ & r. & - & - & - \\
\hline Bubarida & 1 & - & - & - & - & $-\quad-$ & r. & - & - & - \\
\hline Chondrillida & 1 & - & - & - & - & $-\quad-$ & - & - & - & - \\
\hline Clionaida & 7 & - & - & - & - & - & - & - & - & - \\
\hline Dendroceratida & 1 & - & - & - & - & - & re & - & - & - \\
\hline Dictyoceratida & 11 & - & - & - & - & $-\quad-$ & . & - & - & - \\
\hline Haplosclerida & 22 & - & - & - & - & - & . & - & - & - \\
\hline Poecilosclerida & 13 & - & - & - & - & - & . & - & - & - \\
\hline Scopalinida & 2 & - & - & - & - & - & . & - & - & - \\
\hline Suberitida & 5 & - & - & - & - & $-\quad-$ & r. & - & - & - \\
\hline Tethyida & 2 & - & - & - & - & $-\quad-$ & r. & - & - & - \\
\hline Tetractinellida & 8 & - & - & - & - & -- & . & - & - & - \\
\hline Verongiida & 10 & - & - & - & - & - & . & - & - & - \\
\hline Homoscleromorpha & 3 & - & - & - & - & $-\quad-$ & 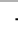 & - & - & - \\
\hline Homosclerophorida & 3 & - & - & - & - & $-\quad-$ & . & - & - & - \\
\hline Rotifera & 20 & - & - & - & - & -- & . & - & - & - \\
\hline Eurotatoria & 20 & - & - & - & - & $-\quad-$ & se & - & - & - \\
\hline Ploima & 20 & - & - & - & - & - & . & - & - & - \\
\hline Plantae & 1453 & 25 & 4 & 2 & 2 & $-\quad-$ & 4 & 11 & 4 & 3 \\
\hline Anthocerotophyta & 4 & - & - & - & - & - - & . & - & - & - \\
\hline Anthocerotopsida & 4 & - & - & - & - & $-\quad-$ & . & - & - & - \\
\hline Anthocerotales & 3 & - & - & - & - & $-\quad-$ & . & - & - & - \\
\hline Dendrocerotales & 1 & - & - & - & - & $-\quad-$ & & - & - & - \\
\hline
\end{tabular}




\begin{tabular}{|c|c|c|c|c|c|c|c|c|c|c|c|}
\hline Chlorophyta & 102 & - & - & - & - & - & - & - & - & -1 & - \\
\hline Ulvophyceae & 102 & - & - & - & - & - & -1 & 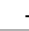 & -1 & -1 & - \\
\hline Bryopsidales & 50 & - & - & - & - & - & - & - & -1 & -1 & - \\
\hline Cladophorales & 31 & - & - & - & - & - & - & & -1 & -1 & - \\
\hline Dasycladales & 10 & - & - & - & - & - & - & & -1 & -1 & - \\
\hline Ulvales & 10 & - & - & - & - & - & - & & -1 & -1 & - \\
\hline Ulvophyceae incerta sedis & 1 & - & - & - & - & - & -1 & & -1 & -1 & - \\
\hline Rhodophyta & 158 & 3 & 1 & - & 1 & - & - & & - & -1 & 2 \\
\hline Florideophyceae & 157 & 3 & 1 & - & 1 & - & -1 & 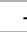 & -1 & -1 & 2 \\
\hline Acrochaetiales & 1 & - & - & - & - & - & -1 & 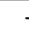 & - & -1 & - \\
\hline Bonnemaisoniales & 1 & - & - & - & - & - & - & 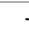 & - & - & - \\
\hline Ceramiales & 80 & 1 & 1 & - & 1 & - & -1 & 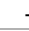 & -1 & -1 & - \\
\hline Colaconematales & 1 & - & - & - & - & - & -1 & 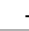 & -1 & -1 & - \\
\hline Corallinales & 16 & - & - & - & - & - & - & 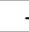 & - & - & - \\
\hline Gelidiales & 4 & - & - & - & - & - & -1 & 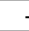 & -1 & -1 & - \\
\hline Gigartinales & 14 & 1 & - & - & - & - & - & - & - & -1 & 1 \\
\hline Gracilariales & 8 & - & - & - & - & - & - & 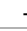 & - & - & - \\
\hline Halymeniales & 4 & - & - & - & - & - & -1 & - & -1 & -1 & - \\
\hline Nemaliales & 14 & - & - & - & - & - & - & - & - & -1 & - \\
\hline Peyssonneliales & 3 & 1 & - & - & - & - & - & - & - & - & 1 \\
\hline Rhodymeniales & 11 & - & - & - & - & - & - & - & - & -1 & - \\
\hline Stylonematophyceae & 1 & - & - & - & - & - & - & - & - & -1 & - \\
\hline Stylonematales & 1 & - & - & - & - & - & -1 & 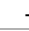 & -1 & -1 & - \\
\hline Tracheophyta & 1189 & 22 & 3 & 2 & 1 & - & - & 4 & 11 & 4 & 1 \\
\hline Cycadopsida & 2 & - & - & - & - & - & - & - & - & - & - \\
\hline Cycadales & 2 & - & - & - & - & - & - & 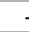 & -1 & -1 & - \\
\hline Lycopodiopsida & 6 & - & - & - & - & - & -1 & - & -1 & -1 & - \\
\hline Lycopodiales & 3 & - & - & - & - & - & - & 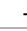 & - & - & - \\
\hline Selaginellales & 3 & - & - & - & - & - & -1 & 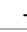 & -1 & -1 & - \\
\hline Magnoliopsida & 1 & - & - & - & - & - & - & - & - & -1 & - \\
\hline Dipsacales & 1 & - & - & - & - & - & -1 & - & -1 & -1 & - \\
\hline Pinopsida & 1 & - & - & - & - & - & -1 & 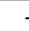 & - & -1 & - \\
\hline Pinales & 1 & - & - & - & - & - & - & - & - & -1 & - \\
\hline Polypodiopsida & 95 & 1 & - & - & - & - & - & - & 1 & -1 & - \\
\hline Cyatheales & 5 & - & - & - & - & - & -1 & 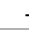 & -1 & -1 & - \\
\hline Gleicheniales & 1 & - & - & - & - & - & -1 & - & -1 & -1 & - \\
\hline Hymenophyllales & 11 & - & - & - & - & - & -1 & 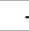 & -1 & -1 & - \\
\hline Polypodiales & 78 & 1 & - & - & - & - & -1 & 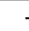 & 1 & -1 & - \\
\hline Psilotopsida & 2 & - & - & - & - & - & - & - & - & - & - \\
\hline Ophioglossales & 1 & - & - & - & - & - & -1 & 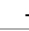 & -1 & -1 & - \\
\hline Psilotales & 1 & - & - & - & - & - & -1 & 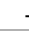 & -1 & -1 & - \\
\hline Spermatopsida & 1082 & 21 & 3 & 2 & 1 & - & - & 4 & 10 & 4 & 1 \\
\hline Alismatales & 19 & - & - & - & - & - & - & - & - & - & - \\
\hline Apiales & 3 & - & - & - & - & - & -1 & - & -1 & -1 & - \\
\hline Aquifoliales & 1 & - & - & - & - & - & -1 & - & - & -1 & - \\
\hline Arecales & 7 & - & - & - & - & - & - & . & - & -1 & - \\
\hline Asparagales & 77 & 4 & - & - & - & - & -1 & 1 & 2 & 1 & - \\
\hline Asterales & 62 & 1 & - & - & - & - & -1 & 1 & -1 & -1 & - \\
\hline Boraginales & 19 & 1 & - & - & - & - & -1 & 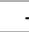 & 1 & -1 & - \\
\hline Brassicales & 21 & - & - & - & - & - & - & 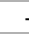 & - & -1 & - \\
\hline Canellales & 1 & - & - & - & - & - & -1 & - & -1 & -1 & - \\
\hline Caryophyllales & 89 & 2 & - & - & - & - & -1 & 1 & -1 & 1 & - \\
\hline Celastrales & 5 & - & - & - & - & - & -1 & 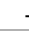 & -1 & -1 & - \\
\hline Commelinales & 8 & - & - & - & - & - & - & - & - & - & - \\
\hline Cucurbitales & 8 & 1 & - & - & - & - & -1 & 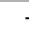 & 1 & -1 & - \\
\hline Dioscoreales & 3 & - & - & - & - & - & -1 & - & - & -1 & - \\
\hline Ericales & 15 & - & - & - & - & - & - & - & - & -1 & - \\
\hline Fabales & 85 & 2 & 1 & 1 & - & - & - & - & 1 & - & - \\
\hline Fagales & 1 & - & - & - & - & - & - & - & - & -1 & - \\
\hline Gentianales & 64 & 3 & - & - & - & - & - & 1 & - & 1 & 1 \\
\hline Lamiales & 69 & 1 & - & - & - & - & -1 & 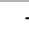 & 1 & -1 & - \\
\hline Laurales & 9 & 1 & - & - & - & - & -1 & 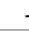 & 1 & - & - \\
\hline Liliales & 2 & - & - & - & - & - & -1 & 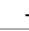 & -1 & - & - \\
\hline Magnoliales & 4 & - & - & - & - & - & -1 & 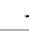 & -1 & - & - \\
\hline Malpighiales & 97 & 1 & - & - & - & - & -1 & 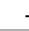 & 1 & - & - \\
\hline Malvales & 59 & - & - & - & - & - & - & - & - & - & - \\
\hline Myrtales & 40 & 2 & 1 & 1 & - & - & - & 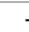 & 1 & - & - \\
\hline Nymphaeales & 1 & - & - & - & - & - & - & . & - & - & - \\
\hline Oxalidales & 5 & - & - & - & - & - & - & 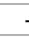 & - & - & - \\
\hline Picramniales & 1 & - & - & - & - & - & -1 & - & -1 & - & - \\
\hline Piperales & 25 & - & - & - & - & - & - & - & - & - & - \\
\hline Poales & 141 & - & - & - & - & - & - & 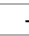 & - & - & - \\
\hline Ranunculales & 3 & - & - & - & - & - & - & - & - & - & - \\
\hline Rosales & 30 & 1 & - & - & - & - & -1 & 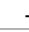 & -1 & 1 & - \\
\hline Santalales & 3 & - & - & - & - & - & -1 & 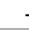 & -1 & - & - \\
\hline Sapindales & 29 & - & - & - & - & - & - & - & -1 & - & - \\
\hline Saxifragales & 4 & - & - & - & - & - & - & & -1 & - & - \\
\hline Solanales & 53 & 1 & 1 & - & 1 & - & - & & 1 & -1 & - \\
\hline Vitales & 3 & - & - & - & - & - & - & & -1 & -1 & - \\
\hline Zingiberales & 11 & - & - & - & - & - & - & - & - & - & - \\
\hline Zygophyllales & 5 & - & - & - & - & - & - & - & - & - & - \\
\hline irand Total & 4114 & 223 & 35 & 12 & 10 & 10 & 3 & 15 & 111 & 58 & 6 \\
\hline
\end{tabular}




\section{Annex 2: Endemic species list of SSS islands and Saba Bank}


Table 15. Endemic animal and plant species for St. Martin, St. Eustatius, Saba and Saba Bank together ('SSS or Saba Bank') and separate, as well as the number of endemics per larger geographical area, with (sub)totals (in grey).

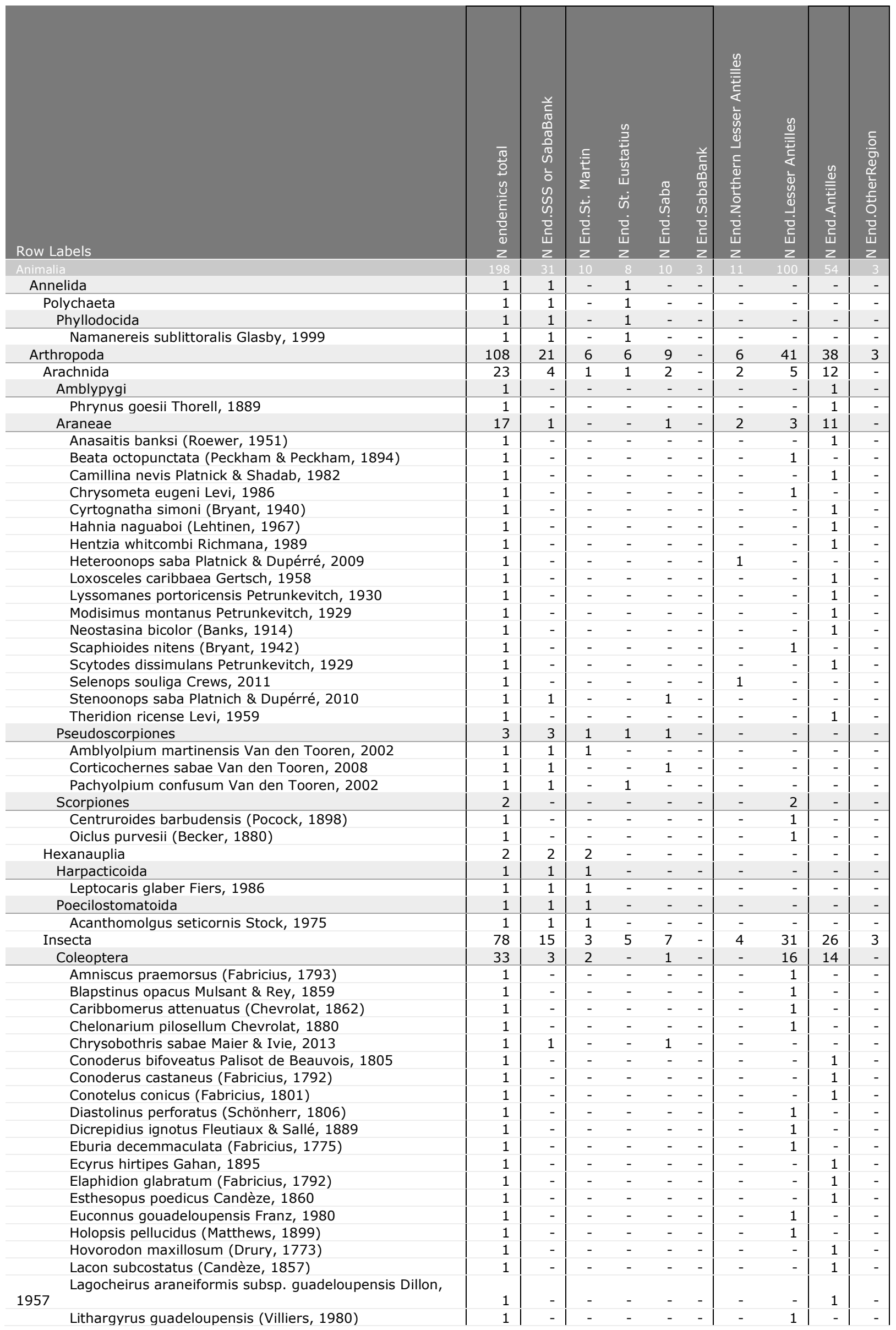


Nemocephalus monilis (Fabricius, 1787)

Neoclytus araneiformis (Olivier, 1795)

Phyllophaga sanbarthensis Chalumeau \& Gruner, 1976

Phyllophaga stehlei Chalumeau, 1985

Psyllobora lineola Fabricius, 1792

Selenophorus parumpunctatus Dejean, 1829

Solenoptera chalumeaui Villiers, 1979

Stethorus caribus Gordon \& Chapin, 1983

Styloleptus inermis (Fabricius, 1801)

Styloleptus posticalis (Gahan, 1895)

Trientoma guadeloupensis Fleutiaux \& Sallé, 1889

Urgleptes cobbeni Gilmour, 1963

Zeadalopus antiguensis Peck \& Cook, 2014

Diptera

Aedes busckii (Coquillett, 1906)

Alepia apexalba Wagner, Richardson \& Richardson, 2010

Allograpta limbata (Fabricius, 1805)

Ocyptamus cylindricus (Fabricius, 1781)

Hemiptera

Chariesterus gracilicornis Stål, 1870

Dysdercus andreae (Linnaeus, 1758)

Lophoscutus geijskesi Kormilev \& van Doesburg, 1986

Hymenoptera

Anthophora eustatiensis Brooks, 1999

Centris smithii Cresson, 1879

Xylocopa mordax Smith, 1874

Lepidoptera

Anaea troglodyta subsp. minor Hall, 1936

Choranthus vitellius (Fabricius, 1793)

Dryas iulia subsp. warneri (Hall, 1936)

Electrostrymon angerona (Godman \& Salvin, 1896)

Glutophrissa drusilla subsp. comstocki (Dillon, 1947)

Glutophrissa punctifera (d'Almeida, 1939)

Leptotes cassius subsp. catilina (Fabricius, 1793)

Phyprosopus tristriga Möschler, 1890

Polygonus savigny subsp. punctus Bell \& Comstock,

1948

Pyrisitia leuce subsp. antillarum (Hall, 1936)

Urbanus obscurus (Hewitson, 1867)

Wallengrenia ophites (Mabille, 1878)

Odonata

Orthemis macrostigma (Rambur, 1842)

Orthoptera

Amphiacusta sanctaecrucis Desutter-Grandcolas, 1997

Antillicharis fulvescens (Saussure, 1878)

Antillicharis naskreckii Otte \& Perez-Gelabert, 2009

Antillicharis sabaensis Otte \& Perez-Gelabert, 2009

Caribacusta saba (Desutter-Grandcolas, 1997)

Carylla proalbifrons (Desutter-Grandcolas, 2003)

Cycloptilum eustatiensis Bland \& Desutter-Grandcolas,

2003

Cyrtoxipha gundlachi (Bland \& Desutter-Grandcolas,

2003)

Cyrtoxipha orientalis (Bland \& Desutter-Grandcolas,

2003)

Lactista eustatia Bland, 2002

Laurellia saba Otte \& Perez-Gelabert, 2009

Laurepa maculata (Desutter-Grandcolas \& Bland, 2003)

Laurepa saba Otte \& Perez-Gelabert, 2009

Microcentrum decoratum Walker, 1869

1878)

Microcentrum incarnatum (Brunner von Wattenwyl,

Nesonotus tricornis (Thunberg, 1815)

Oecanthus allardi Walker \& Gurney, 1960

Orocharis angustus Desutter-Grandcolas, 2003

Orocharis minutus Desutter-Grandcolas, 2003

Phoebolampta caeruleotergum Heads, 2008

Schistocerca nitens subsp. caribbeana Dirsh, 1974

Sphingonotus haitensis (Saussure, 1861)

Malacostraca

Amphipoda

Metaniphargus palpator Stock, 1977

Decapoda

Thersandrus compressus (Desbonne in Desbonne \&

Schramm, 1867)

Isopoda

Gnathia marleyi Farquharson, Smit \& Sikkel, 2012

Microcharon quilli Vonk \& Lau, 2016

Pycnogonida

Pantopoda

Chordata

Tanystylum geminum Stock, 1954

Actinopterygii 
Atheriniformes

Melanorhinus boekei Metzelaar, 1919

Perciformes

Psilotris boehlkei Greenfield, 1993

Starksia melasma Williams \& Mounts, 2003

Starksia williamsi Baldwin \& Castillo, 2011

Amphibia

Anura

Aves

Eleutherodactylus johnstonei Barbour, 1914

Apodiformes

Eulampis holosericeus (Linnaeus, 1758)

Eulampis jugularis (Linnaeus, 1766)

Orthorhyncus cristatus (Linnaeus, 1758)

Orthorhyncus cristatus subsp. exilis (Gmelin, 1788)

Columbiformes

Columbina passerina subsp. nigrirostris (Danforth, 1935)

Columbina passerina subsp. trochila (Bonaparte, 1855)

Geotrygon mystacea (Temminck, 1811)

Falconiformes

Falco sparverius subsp. caribaearum Gmelin, 1788

Passeriformes

Allenia fusca (Müller, 1776)

Cinclocerthia ruficauda (Gould, 1836)

Cinclocerthia ruficauda subsp. pavida Ridgway, 1904

Coereba flaveola subsp. bartholemica (Sparrman, 1788)

Elaenia martinica subsp. martinica (Linnaeus, 1766)

Euphonia musica subsp. flavifrons (Sparrman, 1789)

Loxigilla noctis (Linnaeus, 1766)

Loxigilla noctis subsp. coryi (Ridgway, 1898)

Loxigilla noctis subsp. ridgwayi (Cory, 1892)

Margarops fuscatus subsp. densirostris (Vieillot, 1818)

1879

Quiscalus lugubris subsp. guadeloupensis Lawrence,

1869)

Setophaga petechia subsp. bartholemica (Sundevall,

Tyrannus dominicensis subsp. vorax Vieillot, 1819

Vireo altiloquus subsp. barbadensis (Ridgway, 1874)

Podicipediformes

Podilymbus podiceps subsp. antillarum Bangs, 1913

Chondrichthyes

Carcharhiniformes

Galeus antillensis Springer, 1979

Mammalia

Chiroptera

Ardops nichollsi subsp. montseratensis (Thomas, 1894)

Brachyphylla cavernarum Gray, 1834

Monophyllus plethodon subsp. luciae Miller, 1902

Monophyllus plethodon subsp. plethodon Miller, 1900

Natalus stramineus Gray, 1838

Reptilia

Squamata

Alsophis rijgersmaei Cope, 1869

Alsophis rufiventris Duméril, Bibron \& Duméril, 1854

Anolis bimaculatus (Sparrman, 1784)

Anolis gingivinus Cope, 1864

Anolis pogus Lazell, 1972

Anolis schwartzi (Lazell, 1972)

Anolis sabanus Garman, 1887

Iguana delicatissima Laurenti, 1768

Pholidoscelis erythrocephalus (Shaw, 1802)

Pholidoscelis plei Duméril \& Bibron, 1839

Sphaerodactylus parvus King, 1962

Sphaerodactylus sabanus Cochran, 1938

Sphaerodactylus sputator (Sparrman, 1784)

Spondylurus martinae Hedges \& Conn, 2012

Spondylurus powelli Hedges \& Conn, 2012

Thecadactylus oskrobapreinorum Köhler \& Vesely, 2011 Cnidaria

Anthozoa

Alyconacea

Antillogorgia albatrossae (Bayer, 1961)

Antillogorgia hummelincki (Bayer, 1961)

Zoantharia

Bergia puertoricense (West, 1979)

Hydrozoanthus tunicans (Duerden, 1900)

Hydrozoa

Anthoathecata

Heterocoryne caribbensis Wedler \& Larson, 1986

Mollusca

Bivalvia

Anomalodesmata

Cardiomya saba Knudsen, 1982

\begin{tabular}{|c|c|c|c|c|c|c|c|c|c|}
\hline 1 & 1 & 1 & - & - & - & - & - & - & - \\
\hline 1 & 1 & 1 & - & - & - & - & - & - & - \\
\hline 3 & 1 & - & - & - & 1 & - & 1 & 1 & - \\
\hline 1 & - & - & - & - & - & - & 1 & - & - \\
\hline 1 & - & - & - & - & - & - & - & 1 & - \\
\hline 1 & 1 & - & - & - & 1 & - & - & - & - \\
\hline 1 & - & - & - & - & - & - & 1 & - & - \\
\hline 1 & - & - & - & - & - & - & 1 & - & - \\
\hline 1 & - & - & - & - & - & - & 1 & - & - \\
\hline 23 & - & - & - & - & - & 2 & 15 & 6 & - \\
\hline 4 & - & - & - & - & - & - & 2 & 2 & - \\
\hline 1 & - & - & - & - & - & - & 1 & - & - \\
\hline 1 & - & - & - & - & - & - & 1 & - & - \\
\hline 1 & - & - & - & - & - & - & - & 1 & - \\
\hline 1 & - & - & - & - & - & - & - & 1 & - \\
\hline 3 & - & - & - & - & - & - & 2 & 1 & - \\
\hline 1 & - & - & - & - & - & - & 1 & - & - \\
\hline 1 & - & - & - & - & - & - & 1 & - & - \\
\hline 1 & - & - & - & - & - & - & - & 1 & - \\
\hline 1 & - & - & - & - & - & - & - & 1 & - \\
\hline 1 & - & - & - & - & - & - & - & 1 & - \\
\hline 14 & - & - & - & - & - & 2 & 11 & 1 & - \\
\hline 1 & - & - & - & - & - & - & 1 & - & - \\
\hline 1 & - & - & - & - & - & - & 1 & - & - \\
\hline 1 & - & - & - & - & - & 1 & - & - & - \\
\hline 1 & - & - & - & - & - & - & 1 & - & - \\
\hline 1 & - & - & - & - & - & - & 1 & - & - \\
\hline 1 & - & - & - & - & - & - & 1 & - & - \\
\hline 1 & - & - & - & - & - & - & 1 & - & - \\
\hline 1 & - & - & - & - & - & 1 & - & - & - \\
\hline 1 & - & - & - & - & - & - & 1 & - & - \\
\hline 1 & - & - & - & - & - & - & 1 & - & - \\
\hline 1 & - & - & - & - & - & - & 1 & - & - \\
\hline 1 & - & - & - & - & - & - & - & 1 & - \\
\hline 1 & - & - & - & - & - & - & 1 & - & - \\
\hline 1 & - & - & - & - & - & - & 1 & - & - \\
\hline 1 & - & - & - & - & - & - & - & 1 & - \\
\hline 1 & - & - & - & - & - & - & - & 1 & - \\
\hline 1 & - & - & - & - & - & - & - & 1 & - \\
\hline 1 & - & - & - & - & - & - & - & 1 & - \\
\hline 1 & - & - & - & - & - & - & - & 1 & - \\
\hline 5 & - & - & - & - & - & - & 4 & 1 & - \\
\hline 5 & - & - & - & - & - & - & 4 & 1 & - \\
\hline 1 & - & - & - & - & - & - & 1 & - & - \\
\hline 1 & - & - & - & - & - & - & - & 1 & - \\
\hline 1 & - & - & - & - & - & - & 1 & - & - \\
\hline 1 & - & - & - & - & - & - & 1 & - & - \\
\hline 1 & - & - & - & - & - & - & 1 & - & - \\
\hline 16 & 3 & 2 & - & 1 & - & 3 & 10 & - & - \\
\hline 16 & 3 & 2 & - & 1 & - & 3 & 10 & - & - \\
\hline 1 & - & - & - & - & - & 1 & - & - & - \\
\hline 1 & - & - & - & - & - & - & 1 & - & - \\
\hline 1 & - & - & - & - & - & - & 1 & - & - \\
\hline 1 & - & - & - & - & - & - & 1 & - & - \\
\hline 1 & - & - & - & - & - & - & 1 & - & - \\
\hline 1 & - & - & - & - & - & 1 & - & - & - \\
\hline 1 & 1 & - & - & 1 & - & - & - & - & - \\
\hline 1 & - & - & - & - & - & - & 1 & - & - \\
\hline 1 & - & - & - & - & - & - & 1 & - & - \\
\hline 1 & - & - & - & - & - & - & 1 & - & - \\
\hline 1 & - & - & - & - & - & - & 1 & - & - \\
\hline 1 & - & - & - & - & - & 1 & - & - & - \\
\hline 1 & - & - & - & - & - & - & 1 & - & - \\
\hline 1 & 1 & 1 & - & - & - & - & - & - & - \\
\hline 1 & - & - & - & - & - & - & 1 & - & - \\
\hline 1 & 1 & 1 & - & - & - & - & - & - & - \\
\hline 5 & - & - & - & - & - & - & 1 & 4 & - \\
\hline 4 & - & - & - & - & - & - & 1 & 3 & - \\
\hline 2 & - & - & - & - & - & - & 1 & 1 & - \\
\hline 1 & - & - & - & - & - & - & - & 1 & - \\
\hline 1 & - & - & - & - & - & - & 1 & - & - \\
\hline 2 & - & - & - & - & - & - & - & 2 & - \\
\hline 1 & - & - & - & - & - & - & - & 1 & - \\
\hline 1 & - & - & - & - & - & - & - & 1 & - \\
\hline 1 & - & - & - & - & - & - & - & 1 & - \\
\hline 1 & - & - & - & - & - & - & - & 1 & - \\
\hline 1 & - & - & - & - & - & - & - & 1 & - \\
\hline 33 & 4 & 1 & 1 & - & 2 & - & 26 & 3 & - \\
\hline 5 & 1 & - & - & - & 1 & - & 3 & 1 & - \\
\hline 2 & 1 & - & - & - & 1 & - & 1 & - & - \\
\hline 1 & 1 & - & - & & 1 & - & - & - & - \\
\hline
\end{tabular}


Cetomya umbonata (Knudsen, 1982) Lucinida

Parvilucina latens Taylor \& Glover, 2016

Pleurolucina hendersoni Britton, 1972

Venerida

Transennella gerrardi Abbott, 1958

Gastropoda

Cycloneritimorpha

Lucidella plicatula (Pfeiffer, 1849)

Lucidella plicatula subsp. christofori (Pilsbry, 1897)

Lucidella plicatula subsp. plicatula (Pfeiffer, 1849)

Littorinimorpha

Caecum donmoorei Mitchell-Tapping, 1979

Chondropoma ignea Reeve, 1863

Diplopoma crenulatum (Férussac, 1821)

Simulamerelina didyma (Watson, 1886)

Neogastropoda

Aesopus gracilis Faber, 2004

Buchema bellula (Smith, 1882)

Canalispira hoffi (Moolenbeek \& Faber, 1991)

Conasprella berschaueri (Petuch \& Myers, 2014)

Crassispira affinis (Reeve, 1846)

Lyria sabaensis Bail, 1993

Vasum globulus (Lamarck, 1816)

Stylommatophora

Amphibulima patula (Bruguière, 1792)

Brachypodella antiperversa (Férussac, 1832)

Bulimulus diaphanus (Pfeiffer,1855)

Bulimulus diaphanus subsp. diaphanus (Pfeiffer, 1855)

Bulimulus diaphanus subsp. fraterculus (Potiez \&

Michaud, 1835)

Bulimulus lehmanni (Pfeiffer, 1865)

Bulimulus limnoides (Férussac, 1832)

Glyphyalus quillensis de Winter, van Leeuwen \&

Hovestadt, 2016

Hyalosagda subaquila (Shuttleworth, 1854)

Obeliscus swiftianus (Pfeiffer, 1852)

Opeas octogyrum subsp. plicatellum (Guppy, 1868)

Pellicula depressa (Rang, 1835)

Pleurodonte guadeloupensis (Pilsbry, 1889)

Pleurodonte Iychnuchus (Müller, 1774)

Platyhelminthes

Rhabditophora

Polycladida

Alloioplana wyona (Marcus \& Marcus, 1968)

Rhodophyta

Florideophyceae

Ceramiales

Stichothamnion antillarum Vroman

Gigartinales

Flahaultia tegetiformans W.R.Taylor

Peyssonneliales

Peyssonnelia flavescens D.L.Ballant. \& H.Ruiz

Tracheophyta

Polypodiopsida

Polypodiales

Ctenitis meridionalis (Poir.) Ching

Spermatopsida

Asparagales

Epidendrum difforme Jacq.

Epidendrum pallidiflorum Hook.

Psychilis correllii Sauleda

Tolumnia urophylla (Lodd. ex Lindl.) Braem

Asterales

Chromolaena macrantha (Sw.) R.M.King \& H.Rob.

Boraginales

Cordia nesophila I.M.Johnst.

Caryophyllales

Alternanthera crucis (Moq.) Bold.

Coccoloba boxii Sandwith

Cucurbitales

Begonia retusa O.E.Schulz

Fabales

Galactia longiflora Arn.

Galactia nummularia Urb.

Gentianales

Gonolobus aloiensis Krings \& F.S.Axelrod

Mitracarpus polycladus Urb.

Spermacoce bahamensis (Britton) Howard

Lamiales

Justicia eustachiana Jacq.

Laurales 
Cinnamomum falcatum (Mez) R. Howard Malpighiales

Clusia major L.

Myrtales

Calyptranthes boldinghii Urb.

Tetrazygia discolor (L.) DC.

Rosales

Prunus pleuradenia Griseb.

Solanales

Ipomoea sphenophylla Urb.

\begin{tabular}{|r|r|rrrr|rr|r|r|}
1 & - & - & - & - & - & - & 1 & - & - \\
1 & - & - & - & - & - & - & 1 & - & - \\
1 & - & - & - & - & - & - & 1 & - & - \\
2 & 1 & 1 & - & - & - & - & 1 & - & - \\
\hline 1 & 1 & 1 & - & - & - & - & - & - & - \\
1 & - & - & - & - & - & - & 1 & - & - \\
1 & - & - & - & - & - & - & - & 1 & - \\
\hline 1 & - & - & - & - & - & - & - & 1 & - \\
1 & 1 & - & - & - & - & - & 1 & - & - \\
\hline 1 & 1 & - & - & - & - & - & 1 & - & - \\
\hline 223 & $\mathbf{3 5}$ & $\mathbf{1 2}$ & $\mathbf{1 0}$ & $\mathbf{1 0}$ & $\mathbf{3}$ & $\mathbf{1 5}$ & $\mathbf{1 1 1}$ & $\mathbf{5 8}$ & $\mathbf{6}$ \\
\hline
\end{tabular}




\section{Annex 3: Conservation status of species of the SSS islands and Saba Bank}

Table 16. IUCN Conservation status of endemic animal and plant species for St. Martin, St. Eustatius, Saba and Saba Bank together ('SSS or Saba Bank').

\begin{tabular}{|c|c|c|c|c|c|}
\hline Taxa & 章 & 2 & $\begin{array}{l}\tilde{y} \\
\bar{y} \\
y \\
y \\
0 \\
0 \\
0 \\
0 \\
0 \\
0 \\
0\end{array}$ & $\frac{5}{\frac{0}{4}}$ & Justification \\
\hline \multicolumn{6}{|l|}{ Animalia } \\
\hline \multicolumn{6}{|l|}{ Chordata } \\
\hline \multicolumn{6}{|l|}{ Actinopterygii } \\
\hline \multicolumn{6}{|l|}{ Perciformes } \\
\hline Psilotris boehlkei Greenfield, 1993 & $\begin{array}{l}\text { Yellowspot } \\
\text { Goby }\end{array}$ & LC & $\begin{array}{l}2008- \\
06-30\end{array}$ & 3.1 & $\begin{array}{l}\text { Listed as Least Concern in view of its abundance within } \\
\text { its restricted distribution, its presumed large population, } \\
\text { and because its habitat is unlikely to be declining fast } \\
\text { enough to qualify for listing in a more threatened } \\
\text { category. }\end{array}$ \\
\hline Starksia melasma Williams \& Mounts, 2003 & $\begin{array}{l}\text { Black Spot } \\
\text { Blenny }\end{array}$ & LC & \begin{tabular}{|l|l|}
$18-$ \\
102007
\end{tabular} & 3.1 & $\begin{array}{l}\text { This species is known from Desecheo Island (Puerto } \\
\text { Rico, USA) and Buck Island Reef National Monument (St. } \\
\text { Croix, US Virgin Islands) (Williams and Mount 2003). It } \\
\text { has no major threats. It is listed as Least Concern. }\end{array}$ \\
\hline Starksia williamsi Baldwin \& Castillo, 2011 & NA & LC & \begin{tabular}{|l|l|}
$2015-$ \\
$08-07$ \\
\end{tabular} & 3.1 & $\begin{array}{l}\text { This reef species is widely distributed with no known } \\
\text { major threats. Therefore, it is listed as Least Concern. }\end{array}$ \\
\hline \multicolumn{6}{|r|}{ 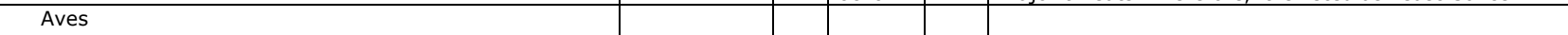 } \\
\hline \multicolumn{6}{|l|}{ Apodiformes } \\
\hline Eulampis holosericeus (Linnaeus, 1758) & $\begin{array}{l}\text { Green- } \\
\text { throated } \\
\text { Carib }\end{array}$ & LC & $\begin{array}{l}2016- \\
10-01\end{array}$ & 3.1 & $\begin{array}{l}\text { Although this species may have a small range, it is not } \\
\text { believed to approach the thresholds for vulnerable under } \\
\text { the range size criterion (Extent of Occurrence }<20,000 \\
\text { km2 combined with a declining or fluctuating range size, } \\
\text { habitat extent/quality, or population size and a small } \\
\text { number of locations or severe fragmentation). The } \\
\text { population trend is not known, but the population is not } \\
\text { believed to be decreasing sufficiently rapidly to approach } \\
\text { the thresholds under the population trend criterion } \\
\text { ( }>30 \% \text { decline over ten years or three generations). The } \\
\text { population size has not been quantified, but it is not } \\
\text { believed to approaach the thresholds for Vulnerable under } \\
\text { the population size criterion ( }<10,000 \text { mature } \\
\text { individuals with a continuing decline estimated to be } \\
>10 \% \text { in ten years or three generations, or with a } \\
\text { specified population structure). For these reasons the } \\
\text { species is evaluated as Least Concern. }\end{array}$ \\
\hline Eulampis jugularis (Linnaeus, 1766) & $\begin{array}{l}\text { Purple- } \\
\text { throated } \\
\text { Carib }\end{array}$ & LC & $\begin{array}{l}2016- \\
10-01\end{array}$ & 3.1 & $\begin{array}{l}\text { Although this species may have a small range, it is not } \\
\text { believed to approach the thresholds for vulnerable under } \\
\text { the range size criterion (Extent of Occurrence }<20,000 \\
\mathrm{~km} 2 \text { combined with a declining or fluctuating range size, } \\
\text { habitat extent/quality, or population size and a small } \\
\text { number of locations or severe fragmentation). The } \\
\text { population trend is not known, but the population is not } \\
\text { believed to be decreasing sufficiently rapidly to approach } \\
\text { the thresholds under the population trend criterion } \\
\text { ( }>30 \% \text { decline over ten years or three generations). The } \\
\text { population size has not been quantified, but it is not } \\
\text { believed to approach the thresholds for vulnerable under } \\
\text { the population size criterion ( }<10,000 \text { mature } \\
\text { individuals with a continuing decline estimated to be } \\
>10 \% \text { in ten years or three generations, or with a } \\
\text { specified population structure). For these reasons the } \\
\text { species is evaluated as Least Concern. }\end{array}$ \\
\hline Orthorhyncus cristatus (Linnaeus, 1758) & $\begin{array}{l}\text { Antillean } \\
\text { Crested } \\
\text { Hummingbir } \\
\text { d }\end{array}$ & LC & $\begin{array}{l}2016- \\
10-01\end{array}$ & 3.1 & $\begin{array}{l}\text { (Subsecies level has not been assessed!) Although this } \\
\text { species may have a small range, it is not believed to } \\
\text { approach the thresholds for Vulnerable under the range } \\
\text { size criterion (Extent of Occurrence }<20,000 \mathrm{~km} 2 \\
\text { combined with a declining or fluctuating range size, } \\
\text { habitat extent/quality, or population size and a small } \\
\text { number of locations or severe fragmentation). The } \\
\text { population trend is not known, but the population is not } \\
\text { believed to be decreasing sufficiently rapidly to approach } \\
\text { the thresholds under the population trend criterion } \\
\text { ( }>30 \% \text { decline over ten years or three generations). The } \\
\text { population size has not been quantified, but it is not } \\
\text { believed to approach the thresholds for Vulnerable under } \\
\text { the population size criterion ( }<10,000 \text { mature } \\
\text { individuals with a continuing decline estimated to be } \\
>10 \% \text { in ten years or three generations, or with a } \\
\text { specified population structure). For these reasons the } \\
\text { species is evaluated as Least Concern. }\end{array}$ \\
\hline Orthorhyncus cristatus subsp. exilis (Gmelin, 1788) & \begin{tabular}{|l|} 
Antillean \\
Crested \\
Hummingbir \\
$d$
\end{tabular} & LC & $\begin{array}{l}2016- \\
10-01\end{array}$ & 3.1 & $\begin{array}{l}\text { (Subspecies level has not been assessed!) Although this } \\
\text { species may have a small range, it is not believed to } \\
\text { approach the thresholds for Vulnerable under the range } \\
\text { size criterion (Extent of Occurrence }<20,000 \mathrm{~km} 2\end{array}$ \\
\hline
\end{tabular}




\begin{tabular}{|c|c|c|c|c|c|}
\hline & & & & & $\begin{array}{l}\text { combined with a declining or fluctuating range size, } \\
\text { habitat extent/quality, or population size and a small } \\
\text { number of locations or severe fragmentation). The } \\
\text { population trend is not known, but the population is not } \\
\text { believed to be decreasing sufficiently rapidly to approach } \\
\text { the thresholds under the population trend criterion } \\
\text { ( }>30 \% \text { decline over ten years or three generations). The } \\
\text { population size has not been quantified, but it is not } \\
\text { believed to approach the thresholds for Vulnerable under } \\
\text { the population size criterion ( }<10,000 \text { mature } \\
\text { individuals with a continuing decline estimated to be } \\
>10 \% \text { in ten years or three generations, or with a } \\
\text { specified population structure). For these reasons the } \\
\text { species is evaluated as Least Concern. }\end{array}$ \\
\hline \multicolumn{6}{|l|}{ Columbiformes } \\
\hline 1935) Columbina passerina subsp. nigrirostris (Danforth, & $\begin{array}{l}\text { Common } \\
\text { Ground Dove }\end{array}$ & LC & $\begin{array}{l}2016- \\
10-01\end{array}$ & 3.1 & $\begin{array}{l}\text { (Subspecies level has not been assessed!) This species } \\
\text { has an extremely large range, and hence does not } \\
\text { approach the thresholds for Vulnerable under the range } \\
\text { size criterion (Extent of Occurrence }<20,000 \mathrm{~km} 2 \\
\text { combined with a declining or fluctuating range size, } \\
\text { habitat extent/quality, or population size and a small } \\
\text { number of locations or severe fragmentation). Despite } \\
\text { the fact that the population trend appears to be } \\
\text { decreasing, the decline is not believed to be sufficiently } \\
\text { rapid to approach the thresholds for Vulnerable under } \\
\text { the population trend criterion ( }>30 \% \text { decline over ten } \\
\text { years or three generations). The population size is } \\
\text { extremely large, and hence does not approach the } \\
\text { thresholds for Vulnerable under the population size } \\
\text { criterion ( }<10,000 \text { mature individuals with a continuing } \\
\text { decline estimated to be }>10 \% \text { in ten years or three } \\
\text { generations, or with a specified population structure). } \\
\text { For these reasons the species is evaluated as Least } \\
\text { Concern. }\end{array}$ \\
\hline 1855) Columbina passerina subsp. trochila (Bonaparte, & $\begin{array}{l}\text { Common } \\
\text { Ground Dove }\end{array}$ & LC & $\begin{array}{l}2016- \\
10-01\end{array}$ & 3.1 & $\begin{array}{l}\text { (Subspecies level has not been assessed!) This species } \\
\text { has an extremely large range, and hence does not } \\
\text { approach the thresholds for Vulnerable under the range } \\
\text { size criterion (Extent of Occurrence }<20,000 \mathrm{~km} 2 \\
\text { combined with a declining or fluctuating range size, } \\
\text { habitat extent/quality, or population size and a small } \\
\text { number of locations or severe fragmentation). Despite } \\
\text { the fact that the population trend appears to be } \\
\text { decreasing, the decline is not believed to be sufficiently } \\
\text { rapid to approach the thresholds for Vulnerable under } \\
\text { the population trend criterion ( }>30 \% \text { decline over ten } \\
\text { years or three generations). The population size is } \\
\text { extremely large, and hence does not approach the } \\
\text { thresholds for Vulnerable under the population size } \\
\text { criterion ( }<10,000 \text { mature individuals with a continuing } \\
\text { decline estimated to be }>10 \% \text { in ten years or three } \\
\text { generations, or with a specified population structure). } \\
\text { For these reasons the species is evaluated as Least } \\
\text { Concern. }\end{array}$ \\
\hline Geotrygon mystacea (Temminck, 1811) & $\begin{array}{l}\text { Bridled } \\
\text { Quail-Dove }\end{array}$ & LC & $\begin{array}{l}2016- \\
10-01\end{array}$ & 3.1 & $\begin{array}{l}\text { Although this species may have a small range, it is not } \\
\text { believed to approach the thresholds for Vulnerable under } \\
\text { the range size criterion (Extent of Occurrence }<20,000 \\
\mathrm{~km} 2 \text { combined with a declining or fluctuating range size, } \\
\text { habitat extent/quality, or population size and a small } \\
\text { number of locations or severe fragmentation). Despite } \\
\text { the fact that the population trend appears to be } \\
\text { decreasing, the decline is not believed to be sufficiently } \\
\text { rapid to approach the thresholds for Vulnerable under } \\
\text { the population trend criterion ( }>30 \% \text { decline over ten } \\
\text { years or three generations). The population size has not } \\
\text { been quantified, but it is not believed to approach the } \\
\text { thresholds for Vulnerable under the population size } \\
\text { criterion ( }<10,000 \text { mature individuals with a continuing } \\
\text { decline estimated to be }>10 \% \text { in ten years or three } \\
\text { generations, or with a specified population structure). } \\
\text { For these reasons the species is evaluated as Least } \\
\text { Concern. }\end{array}$ \\
\hline \multicolumn{6}{|l|}{ Falconiformes } \\
\hline Falco sparverius subsp. caribaearum Gmelin, 1788 & $\begin{array}{l}\text { American } \\
\text { Kestrel }\end{array}$ & LC & $\begin{array}{l}2016- \\
10-01\end{array}$ & 3.1 & $\begin{array}{l}\text { (Subspecies level has not been assessed!) This species } \\
\text { has an extremely large range, and hence does not } \\
\text { approach the thresholds for Vulnerable under the range } \\
\text { size criterion (Extent of Occurrence }<20,000 \mathrm{~km} 2 \\
\text { combined with a declining or fluctuating range size, } \\
\text { habitat extent/quality, or population size and a small } \\
\text { number of locations or severe fragmentation). The } \\
\text { population trend appears to be stable, and hence the } \\
\text { species does not approach the thresholds for Vulnerable } \\
\text { under the population trend criterion ( }>30 \% \text { decline over } \\
\text { ten years or three generations). The population size is } \\
\text { extremely large, and hence does not approach the } \\
\text { thresholds for Vulnerable under the population size } \\
\text { criterion ( }<10,000 \text { mature individuals with a continuing } \\
\text { decline estimated to be }>10 \% \text { in ten years or three } \\
\text { generations, or with a specified population structure). } \\
\text { For these reasons the species is evaluated as Least } \\
\text { Concern. }\end{array}$ \\
\hline \multicolumn{6}{|l|}{ Passeriformes } \\
\hline Allenia fusca (Müller, 1776) & $\begin{array}{l}\text { Scaly- } \\
\text { breasted } \\
\text { Thrasher }\end{array}$ & LC & $\begin{array}{l}2016- \\
10-01\end{array}$ & 3.1 & $\begin{array}{l}\text { Although this species may have a small range, it is not } \\
\text { believed to approach the thresholds for Vulnerable under } \\
\text { the range size criterion (Extent of Occurrence }<20,000 \\
\mathrm{~km} 2 \text { combined with a declining or fluctuating range size, } \\
\text { habitat extent/quality, or population size and a small } \\
\text { number of locations or severe fragmentation). The } \\
\text { population trend is not known, but the population is not } \\
\text { believed to be decreasing sufficiently rapidly to approach }\end{array}$ \\
\hline
\end{tabular}




\begin{tabular}{|c|c|c|c|c|c|}
\hline & & & & & $\begin{array}{l}\text { the thresholds under the population trend criterion } \\
\text { ( }>30 \% \text { decline over ten years or three generations). The } \\
\text { population size has not been quantified, but it is not } \\
\text { believed to approach the thresholds for Vulnerable under } \\
\text { the population size criterion ( }<10,000 \text { mature } \\
\text { individuals with a continuing decline estimated to be } \\
>10 \% \text { in ten years or three generations, or with a } \\
\text { specified population structure). For these reasons the } \\
\text { species is evaluated as Least Concern. }\end{array}$ \\
\hline Cinclocerthia ruficauda (Gould, 1836) & $\begin{array}{l}\text { Brown } \\
\text { Trembler }\end{array}$ & LC & $\begin{array}{l}2016- \\
10-01\end{array}$ & 3.1 & $\begin{array}{l}\text { Although this species may have a small range, it is not } \\
\text { believed to approach the thresholds for Vulnerable under } \\
\text { the range size criterion (Extent of Occurrence }<20,000 \\
\mathrm{~km} 2 \text { combined with a declining or fluctuating range size, } \\
\text { habitat extent/quality, or population size and a small } \\
\text { number of locations or severe fragmentation). The } \\
\text { population trend is not known, but the population is not } \\
\text { believed to be decreasing sufficiently rapidly to approach } \\
\text { the thresholds under the population trend criterion } \\
\text { ( }>30 \% \text { decline over ten years or three generations). The } \\
\text { population size has not been quantified, but it is not } \\
\text { believed to approach the thresholds for Vulnerable under } \\
\text { the population size criterion ( }<10,000 \text { mature } \\
\text { individuals with a continuing decline estimated to be } \\
>10 \% \text { in ten years or three generations, or with a } \\
\text { specified population structure). For these reasons the } \\
\text { species is evaluated as Least Concern. }\end{array}$ \\
\hline Cinclocerthia ruficauda subsp. pavida Ridgway, 1904 & $\begin{array}{l}\text { Brown } \\
\text { Trembler }\end{array}$ & LC & $\begin{array}{l}2016- \\
10-01\end{array}$ & 3.1 & $\begin{array}{l}\text { (Subspecies level has not been assessed!) Although this } \\
\text { species may have a small range, it is not believed to } \\
\text { approach the thresholds for Vulnerable under the range } \\
\text { size criterion (Extent of Occurrence }<20,000 \mathrm{~km} 2 \\
\text { combined with a declining or fluctuating range size, } \\
\text { habitat extent/quality, or population size and a small } \\
\text { number of locations or severe fragmentation). The } \\
\text { population trend is not known, but the population is not } \\
\text { believed to be decreasing sufficiently rapidly to approach } \\
\text { the thresholds under the population trend criterion } \\
\text { ( }>30 \% \text { decline over ten years or three generations). The } \\
\text { population size has not been quantified, but it is not } \\
\text { believed to approach the thresholds for Vulnerable under } \\
\text { the population size criterion ( }<10,000 \text { mature } \\
\text { individuals with a continuing decline estimated to be } \\
>10 \% \text { in ten years or three generations, or with a } \\
\text { specified population structure). For these reasons the } \\
\text { species is evaluated as Least Concern. }\end{array}$ \\
\hline 1788) Coereba flaveola subsp. bartholemica (Sparrman, & Bananaquit & LC & $\begin{array}{l}2016- \\
10-01\end{array}$ & 3.1 & $\begin{array}{l}\text { (Subspecies level has not been assessed!) This species } \\
\text { has an extremely large range, and hence does not } \\
\text { approach the thresholds for Vulnerable under the range } \\
\text { size criterion (Extent of Occurrence }<20,000 \mathrm{~km} 2 \\
\text { combined with a declining or fluctuating range size, } \\
\text { habitat extent/quality, or population size and a small } \\
\text { number of locations or severe fragmentation). The } \\
\text { population trend appears to be stable, and hence the } \\
\text { species does not approach the thresholds for Vulnerable } \\
\text { under the population trend criterion ( }>30 \% \text { decline over } \\
\text { ten years or three generations). The population size is } \\
\text { extremely large, and hence does not approach the } \\
\text { thresholds for Vulnerable under the population size } \\
\text { criterion ( }<10,000 \text { mature individuals with a continuing } \\
\text { decline estimated to be }>10 \% \text { in ten years or three } \\
\text { generations, or with a specified population structure). } \\
\text { For these reasons the species is evaluated as Least } \\
\text { Concern. }\end{array}$ \\
\hline Elaenia martinica subsp. martinica (Linnaeus, 1766) & $\begin{array}{l}\text { Caribbean } \\
\text { Elaenia }\end{array}$ & LC & $\begin{array}{l}2016- \\
10-01\end{array}$ & 3.1 & $\begin{array}{l}\text { (Subspecies level has not been assessed!) Although this } \\
\text { species may have a restricted range, it is not believed to } \\
\text { approach the thresholds for Vulnerable under the range } \\
\text { size criterion (Extent of Occurrence }<20,000 \mathrm{~km} 2 \\
\text { combined with a declining or fluctuating range size, } \\
\text { habitat extent/quality, or population size and a small } \\
\text { number of locations or severe fragmentation). The } \\
\text { population trend is not known, but the population is not } \\
\text { believed to be decreasing sufficiently rapidly to approach } \\
\text { the thresholds under the population trend criterion } \\
\text { ( }>30 \% \text { decline over ten years or three } \\
\text { generations). The population size may be moderately } \\
\text { small to large, but it is not believed to approach the } \\
\text { thresholds for Vulnerable under the population size } \\
\text { criterion ( }<10,000 \text { mature individuals with a continuing } \\
\text { decline estimated to be }>10 \% \text { in ten years or three } \\
\text { generations, or with a specified population } \\
\text { structure). For these reasons the species is evaluated } \\
\text { as Least Concern. }\end{array}$ \\
\hline Euphonia musica subsp. flavifrons (Sparrman, 1789) & $\begin{array}{l}\text { Lesser } \\
\text { Antillean } \\
\text { Euphonia }\end{array}$ & LC & $\begin{array}{l}2016- \\
10-01\end{array}$ & 3.1 & $\begin{array}{l}\text { (Subspecies level has not been assessed!) This species } \\
\text { has a very large range, and hence does not approach } \\
\text { the thresholds for Vulnerable under the range size } \\
\text { criterion (Extent of Occurrence }<20,000 \mathrm{~km} 2 \text { combined } \\
\text { with a declining or fluctuating range size, habitat } \\
\text { extent/quality, or population size and a small number of } \\
\text { locations or severe fragmentation). The population trend } \\
\text { appears to be stable, and hence the species does not } \\
\text { approach the thresholds for Vulnerable under the } \\
\text { population trend criterion ( }>30 \% \text { decline over ten years } \\
\text { or three generations). The population size has not been } \\
\text { quantified, but it is not believed to approach the } \\
\text { thresholds for Vulnerable under the population size } \\
\text { criterion ( }<10,000 \text { mature individuals with a continuing } \\
\text { decline estimated to be }>10 \% \text { in ten years or three } \\
\text { generations, or with a specified population structure). } \\
\text { For these reasons the species is evaluated as Least } \\
\text { Concern. }\end{array}$ \\
\hline Loxigilla noctis (Linnaeus, 1766) & \begin{tabular}{|l|} 
Lesser \\
Antillean \\
Bullfinch \\
\end{tabular} & LC & $\begin{array}{l}2016- \\
10-01\end{array}$ & 3.1 & $\begin{array}{l}\text { Although this species may have a small range, it is not } \\
\text { believed to approach the thresholds for Vulnerable under } \\
\text { the range size criterion (extent of occurrence }<20,000\end{array}$ \\
\hline
\end{tabular}




\begin{tabular}{|c|c|c|c|c|c|}
\hline & & & & & $\begin{array}{l}\mathrm{km}^{2} \text { combined with a declining or fluctuating range size, } \\
\text { habitat extent/quality, or population size and a small } \\
\text { number of locations or severe fragmentation). The } \\
\text { population trend appears to be stable, and hence the } \\
\text { species does not approach the thresholds for Vulnerable } \\
\text { under the population trend criterion ( }>30 \% \text { decline over } \\
\text { ten years or three generations). The population size has } \\
\text { not been quantified, but it is not believed to approach } \\
\text { the thresholds for Vulnerable under the population size } \\
\text { criterion ( }<10,000 \text { mature individuals with a continuing } \\
\text { decline estimated to be }>10 \% \text { in ten years or three } \\
\text { generations, or with a specified population structure). } \\
\text { For these reasons the species is evaluated as Least } \\
\text { Concern. }\end{array}$ \\
\hline Loxigilla noctis subsp. coryi (Ridgway, 1898) & $\begin{array}{l}\text { Lesser } \\
\text { Antillean } \\
\text { Bullfinch }\end{array}$ & LC & $\begin{array}{l}2016- \\
10-01\end{array}$ & 3.1 & $\begin{array}{l}\text { (Subspecies level has not been assessed!) Although this } \\
\text { species may have a small range, it is not believed to } \\
\text { approach the thresholds for Vulnerable under the range } \\
\text { size criterion (extent of occurrence }<20,000 \\
\mathrm{~km}^{2} \text { combined with a declining or fluctuating range size, } \\
\text { habitat extent/quality, or population size and a small } \\
\text { number of locations or severe fragmentation). The } \\
\text { population trend appears to be stable, and hence the } \\
\text { species does not approach the thresholds for Vulnerable } \\
\text { under the population trend criterion ( }>30 \% \text { decline over } \\
\text { ten years or three generations). The population size has } \\
\text { not been quantified, but it is not believed to approach } \\
\text { the thresholds for Vulnerable under the population size } \\
\text { criterion ( }<10,000 \text { mature individuals with a continuing } \\
\text { decline estimated to be }>10 \% \text { in ten years or three } \\
\text { generations, or with a specified population structure). } \\
\text { For these reasons the species is evaluated as Least } \\
\text { Concern. }\end{array}$ \\
\hline Loxigilla noctis subsp. ridgwayi (Cory, 1892) & $\begin{array}{l}\text { Lesser } \\
\text { Antillean } \\
\text { Bullfinch }\end{array}$ & LC & $\begin{array}{l}2016- \\
10-01\end{array}$ & 3.1 & $\begin{array}{l}\text { (Subspecies level has not been assessed!) Although this } \\
\text { species may have a small range, it is not believed to } \\
\text { approach the thresholds for Vulnerable under the range } \\
\text { size criterion (extent of occurrence }<20,000 \\
\mathrm{~km}^{2} \text { combined with a declining or fluctuating range size, } \\
\text { habitat extent/quality, or population size and a small } \\
\text { number of locations or severe fragmentation). The } \\
\text { population trend appears to be stable, and hence the } \\
\text { species does not approach the thresholds for Vulnerable } \\
\text { under the population trend criterion ( }>30 \% \text { decline over } \\
\text { ten years or three generations). The population size has } \\
\text { not been quantified, but it is not believed to approach } \\
\text { the thresholds for Vulnerable under the population size } \\
\text { criterion ( }<10,000 \text { mature individuals with a continuing } \\
\text { decline estimated to be }>10 \% \text { in ten years or three } \\
\text { generations, or with a specified population structure). } \\
\text { For these reasons the species is evaluated as Least } \\
\text { Concern. }\end{array}$ \\
\hline 1818) Margarops fuscatus subsp. densirostris (Vieillot, & $\begin{array}{l}\text { Pearly-eyed } \\
\text { Thrasher }\end{array}$ & LC & $\begin{array}{l}2016- \\
10-01\end{array}$ & 3.1 & $\begin{array}{l}\text { Although this species may have a restricted range, it is } \\
\text { not believed to approach the thresholds for Vulnerable } \\
\text { under the range size criterion (Extent of Occurrence } \\
<20,000 \mathrm{~km} 2 \text { combined with a declining or fluctuating } \\
\text { range size, habitat extent/quality, or population size and } \\
\text { a small number of locations or severe fragmentation). } \\
\text { The population trend appears to be stable, and hence } \\
\text { the species does not approach the thresholds for } \\
\text { Vulnerable under the population trend criterion ( }>30 \% \\
\text { decline over ten years or three generations). The } \\
\text { population size has not been quantified, but it is not } \\
\text { believed to approach the thresholds for Vulnerable under } \\
\text { the population size criterion ( }<10,000 \text { mature } \\
\text { individuals with a continuing decline estimated to be } \\
>10 \% \text { in ten years or three generations, or with a } \\
\text { specified population structure). For these reasons the } \\
\text { species is evaluated as Least Concern. }\end{array}$ \\
\hline 1879 Quiscalus lugubris subsp. guadeloupensis Lawrence, & $\begin{array}{l}\text { Carib } \\
\text { Grackle }\end{array}$ & LC & $\begin{array}{l}2016- \\
10-01\end{array}$ & 3.1 & $\begin{array}{l}\text { (Subspecies level has not been assessed!) This species } \\
\text { has a very large range, and hence does not approach } \\
\text { the thresholds for Vulnerable under the range size } \\
\text { criterion (Extent of Occurrence }<20,000 \mathrm{~km} 2 \text { combined } \\
\text { with a declining or fluctuating range size, habitat } \\
\text { extent/quality, or population size and a small number of } \\
\text { locations or severe fragmentation). The population trend } \\
\text { appears to be stable, and hence the species does not } \\
\text { approach the thresholds for Vulnerable under the } \\
\text { population trend criterion ( }>30 \% \text { decline over ten years } \\
\text { or three generations). The population size has not been } \\
\text { quantified, but it is not believed to approach the } \\
\text { thresholds for Vulnerable under the population size } \\
\text { criterion ( }<10,000 \text { mature individuals with a continuing } \\
\text { decline estimated to be }>10 \% \text { in ten years or three } \\
\text { generations, or with a specified population structure). } \\
\text { For these reasons the species is evaluated as Least } \\
\text { Concern. }\end{array}$ \\
\hline $\begin{array}{l}\text { Setophaga petechia subsp. bartholemica (Sundevall, } \\
\text { 1869) }\end{array}$ & $\begin{array}{l}\text { Mangrove } \\
\text { Warbler }\end{array}$ & LC & $\begin{array}{l}2016- \\
10-01\end{array}$ & 3.1 & $\begin{array}{l}\text { (Subspecies level has not been assessed!) This species } \\
\text { has an extremely large range, and hence does not } \\
\text { approach the thresholds for Vulnerable under the range } \\
\text { size criterion (Extent of Occurrence }<20,000 \mathrm{~km} 2 \\
\text { combined with a declining or fluctuating range size, } \\
\text { habitat extent/quality, or population size and a small } \\
\text { number of locations or severe fragmentation). The } \\
\text { population trend appears to be stable, and hence the } \\
\text { species does not approach the thresholds for Vulnerable } \\
\text { under the population trend criterion ( }>30 \% \text { decline over } \\
\text { ten years or three generations). The population size is } \\
\text { extremely large, and hence does not approach the } \\
\text { thresholds for Vulnerable under the population size } \\
\text { criterion ( }<10,000 \text { mature individuals with a continuing } \\
\text { decline estimated to be }>10 \% \text { in ten years or three } \\
\text { generations, or with a specified population structure). }\end{array}$ \\
\hline
\end{tabular}




\begin{tabular}{|c|c|c|c|c|c|}
\hline & & & & & $\begin{array}{l}\text { For these reasons the species is evaluated as Least } \\
\text { Concern. }\end{array}$ \\
\hline Tyrannus dominicensis subsp. vorax Vieillot, 1819 & $\begin{array}{l}\text { Grey } \\
\text { Kingbird }\end{array}$ & LC & $\begin{array}{l}2016- \\
10-01\end{array}$ & 3.1 & $\begin{array}{l}\text { This species has a very large range, and hence does not } \\
\text { approach the thresholds for Vulnerable under the range } \\
\text { size criterion (Extent of Occurrence }<20,000 \mathrm{~km} 2 \\
\text { combined with a declining or fluctuating range size, } \\
\text { habitat extent/quality, or population size and a small } \\
\text { number of locations or severe fragmentation). The } \\
\text { population trend appears to be stable, and hence the } \\
\text { species does not approach the thresholds for Vulnerable } \\
\text { under the population trend criterion ( }>30 \% \text { decline over } \\
\text { ten years or three generations). The population size is } \\
\text { very large, and hence does not approach the thresholds } \\
\text { for Vulnerable under the population size criterion } \\
\text { ( }<10,000 \text { mature individuals with a continuing decline } \\
\text { estimated to be }>10 \% \text { in ten years or three generations, } \\
\text { or with a specified population structure). For these } \\
\text { reasons the species is evaluated as Least Concern. }\end{array}$ \\
\hline Vireo altiloquus subsp. barbadensis (Ridgway, 1874) & $\begin{array}{l}\text { Barbados } \\
\text { Black- } \\
\text { whiskered } \\
\text { Vireo }\end{array}$ & LC & $\begin{array}{l}2016- \\
10-01\end{array}$ & 3.1 & $\begin{array}{l}\text { (Subspecies level has not been assessed!) This species } \\
\text { has a very large range, and hence does not approach } \\
\text { the thresholds for Vulnerable under the range size } \\
\text { criterion (Extent of Occurrence }<20,000 \mathrm{~km} 2 \text { combined } \\
\text { with a declining or fluctuating range size, habitat } \\
\text { extent/quality, or population size and a small number of } \\
\text { locations or severe fragmentation). The population trend } \\
\text { is not known, but the population is not believed to be } \\
\text { decreasing sufficiently rapidly to approach the } \\
\text { thresholds under the population trend criterion ( }>30 \% \\
\text { decline over ten years or three generations). The } \\
\text { population size is very large, and hence does not } \\
\text { approach the thresholds for Vulnerable under the } \\
\text { population size criterion ( }<10,000 \text { mature individuals } \\
\text { with a continuing decline estimated to be }>10 \% \text { in ten } \\
\text { years or three generations, or with a specified } \\
\text { population structure). For these reasons the species is } \\
\text { evaluated as Least Concern. }\end{array}$ \\
\hline \multicolumn{6}{|l|}{ Podicipediformes } \\
\hline Podilymbus podiceps subsp. antillarum Bangs, 1913 & $\begin{array}{l}\text { Pied-billed } \\
\text { Grebe }\end{array}$ & LC & $\begin{array}{l}2016- \\
10-01\end{array}$ & 3.1 & $\begin{array}{l}\text { This species has an extremely large range, and hence } \\
\text { does not approach the thresholds for Vulnerable under } \\
\text { the range size criterion (Extent of Occurrence }<20,000 \\
\mathrm{~km} 2 \text { combined with a declining or fluctuating range size, } \\
\text { habitat extent/quality, or population size and a small } \\
\text { number of locations or severe fragmentation). The } \\
\text { population trend appears to be stable, and hence the } \\
\text { species does not approach the thresholds for Vulnerable } \\
\text { under the population trend criterion ( }>30 \% \text { decline over } \\
\text { ten years or three generations). The population size is } \\
\text { very large, and hence does not approach the thresholds } \\
\text { for Vulnerable under the population size criterion } \\
\text { ( }<10,000 \text { mature individuals with a continuing decline } \\
\text { estimated to be }>10 \% \text { in ten years or three generations, } \\
\text { or with a specified population structure). For these } \\
\text { reasons the species is evaluated as Least Concern. }\end{array}$ \\
\hline \multicolumn{6}{|l|}{ Chondrichthyes } \\
\hline \multicolumn{6}{|l|}{ Carcharhiniformes } \\
\hline Galeus antillensis Springer, 1979 & $\begin{array}{l}\text { Antilles } \\
\text { Catshark }\end{array}$ & $\mathrm{DD}$ & $\begin{array}{l}2004- \\
06-16\end{array}$ & 3.1 & $\begin{array}{l}\text { The Antilles Catshark (Galeus antillensis) is a member of } \\
\text { the western Atlantic Galeus arae species complex. } \\
\text { Information for this species is currently limited but it } \\
\text { appears to have a relatively restricted distribution in the } \\
\text { western central Atlantic (Florida Straits, Hispaniola, } \\
\text { Puerto Rico and the Lesser Antilles). Its distribution may } \\
\text { not be completely documented due in part to confusion } \\
\text { with its congeners. This species is found in depths of } \\
293-695 \mathrm{~m} \text { and reaches a maximum size of } \sim 46 \mathrm{~cm} \\
\text { total length, but virtually nothing is known of its biology. } \\
\text { Very little information is available on fisheries that may } \\
\text { take this species as bycatch and no catch data are } \\
\text { available. At present there is not enough information on } \\
\text { catches, biology, or population to assess the species } \\
\text { beyond Data Deficient. The limited distribution of this } \\
\text { species may make it vulnerable to depletion and } \\
\text { therefore any catches require monitoring. }\end{array}$ \\
\hline \multicolumn{6}{|l|}{ Mammalia } \\
\hline \multicolumn{6}{|l|}{ Chiroptera } \\
\hline 1894) Ardops nichollsi subsp. montseratensis (Thomas, & $\begin{array}{l}\text { Antillean } \\
\text { Tree Bat }\end{array}$ & LC & $\begin{array}{l}2008- \\
06-30\end{array}$ & 3.1 & $\begin{array}{l}\text { (Subspecies level has not been assessed!) Listed as } \\
\text { Least Concern in view of its abundance within its } \\
\text { restricted distribution, its presumed large population, } \\
\text { and because its habitat is unlikely to be declining fast } \\
\text { enough to qualify for listing in a more threatened } \\
\text { category }\end{array}$ \\
\hline Brachyphylla cavernarum Gray, 1834 & \begin{tabular}{|l} 
Antillean \\
Fruit-eating \\
Bat
\end{tabular} & LC & $\begin{array}{l}2008- \\
06-30\end{array}$ & 3.1 & $\begin{array}{l}\text { Listed as Least Concern in view of its abundance within } \\
\text { its restricted distribution, its presumed large population, } \\
\text { occurrence in a number of protected areas, tolerance to } \\
\text { some degree of habitat modification, and because its } \\
\text { habitat is unlikely to be declining fast enough to qualify } \\
\text { for listing in a more threatened category. }\end{array}$ \\
\hline Monophyllus plethodon subsp. luciae Miller, 1902 & \begin{tabular}{|l|} 
Insular \\
Single-leaf \\
Bat
\end{tabular} & LC & $\begin{array}{l}2008- \\
06-30\end{array}$ & 3.1 & $\begin{array}{l}\text { (Subspecies level has not been assessed!) Listed as } \\
\text { Least Concern because its presumed large population, } \\
\text { and because its habitat is unlikely to be declining fast } \\
\text { enough to qualify for listing in a more threatened } \\
\text { category. }\end{array}$ \\
\hline 1900 Monophyllus plethodon subsp. plethodon Miller, & \begin{tabular}{|l} 
Insular \\
Single-leaf \\
Bat
\end{tabular} & LC & $\begin{array}{l}2008- \\
06-30\end{array}$ & 3.1 & $\begin{array}{l}\text { (Subspecies level has not been assessed!) Listed as } \\
\text { Least Concern because its presumed large population, } \\
\text { and because its habitat is unlikely to be declining fast } \\
\text { enough to qualify for listing in a more threatened } \\
\text { category. }\end{array}$ \\
\hline
\end{tabular}




\begin{tabular}{|c|c|c|c|c|c|}
\hline Natalus stramineus Gray, 1838 & $\begin{array}{l}\text { Greater } \\
\text { Funnel-eared } \\
\text { Bat }\end{array}$ & LC & \begin{tabular}{|l|}
$2016-$ \\
$07-09$
\end{tabular} & 3.1 & $\begin{array}{l}\text { Listed as Least Concern in view of its abundance within } \\
\text { its restricted distribution, its presumed large population, } \\
\text { and because its habitat is unlikely to be declining fast } \\
\text { enough to qualify for listing in a more threatened catego }\end{array}$ \\
\hline \multicolumn{6}{|r|}{ 年 } \\
\hline \multicolumn{6}{|l|}{ Squamata } \\
\hline Alsophis rijgersmaei Cope, 1869 & $\begin{array}{l}\text { Anguilla } \\
\text { Bank Racer }\end{array}$ & EN & \begin{tabular}{|l|}
$2015-$ \\
$07-20$
\end{tabular} & 3.1 & $\begin{array}{l}\text { Listed as Endangered on the basis that this species has } \\
\text { an extent of occurrence little over } 1,000 \mathrm{~km}^{2} \text { and is } \\
\text { known to survive on only five islands, each of which is } \\
\text { considered a single location based on widespread } \\
\text { threats from development, including the likely } \\
\text { eradication of the population from Scrub Island following } \\
\text { planned development. The population on St. Barths is } \\
\text { however presently viable and probably subject to at } \\
\text { most localized threats, and while threats to Anguilla are } \\
\text { severe it is not yet clear how severe declines have been. }\end{array}$ \\
\hline Alsophis rufiventris Duméril, Bibron \& Duméril, 1854 & Saba Racer & VU & \begin{tabular}{|l|}
$2015-$ \\
$07-21$
\end{tabular} & 3.1 & $\begin{array}{l}\text { Listed as Vulnerable on the basis of a plausible future } \\
\text { threat mainly from mongoose introduction, which has } \\
\text { led to this species being lost from the majority of its } \\
\text { historical range and would rapidly drive this species } \\
\text { (known from subpopulations on two small islands with a } \\
\text { combined area, and so a maximum area of occupancy, } \\
\text { of } 34 \mathrm{~km}^{2} \text { ), a risk that is increasing due to increasing } \\
\text { traffic between these islands and larger nearby islands } \\
\text { on which this invasive predator is established. There is a } \\
\text { lesser potential threat from increases in cat populations } \\
\text { as the human population expands, and feral cats are } \\
\text { now established on one of the two islands, however at } \\
\text { present the snake remains abundant with an apparently } \\
\text { stable population. }\end{array}$ \\
\hline Anolis bimaculatus (Sparrman, 1784) & $\begin{array}{l}\text { Green Tree } \\
\text { Lizard }\end{array}$ & LC & $\begin{array}{l}2009- \\
06-30\end{array}$ & 3.1 & $\begin{array}{l}\text { Anolis bimaculatus is listed as Least Concern. Although } \\
\text { this species has a restricted range, it is not currently } \\
\text { impacted by any major threat processes, has been } \\
\text { noted as abundant, and is unlikely to be undergoing } \\
\text { population declines. However, as this species has a } \\
\text { restricted range, monitoring is recommended to ensure } \\
\text { that population numbers do not decline in the future. }\end{array}$ \\
\hline Anolis pogus Lazell, 1972 & $\begin{array}{l}\text { Anguilla } \\
\text { Bank Bush } \\
\text { Anole }\end{array}$ & VU & $\begin{array}{l}2009- \\
06-30\end{array}$ & 3.1 & $\begin{array}{l}\text { This species has been assessed as Vulnerable as it is } \\
\text { restricted to one small island. Although no information is } \\
\text { available regarding current threats to this species, it is } \\
\text { obvious from its past extinctions from other islands that } \\
\text { they do exist. Therefore more research and monitoring } \\
\text { should be conducted to ensure that this species does not } \\
\text { decline, triggering assignment to a higher threat } \\
\text { category. }\end{array}$ \\
\hline Iguana delicatissima Laurenti, 1768 & $\begin{array}{l}\text { Lesser } \\
\text { Antillean } \\
\text { Iguana }\end{array}$ & $\mathrm{CR}$ & \begin{tabular}{|l|}
$2018-$ \\
$03-03$
\end{tabular} & 3.1 & 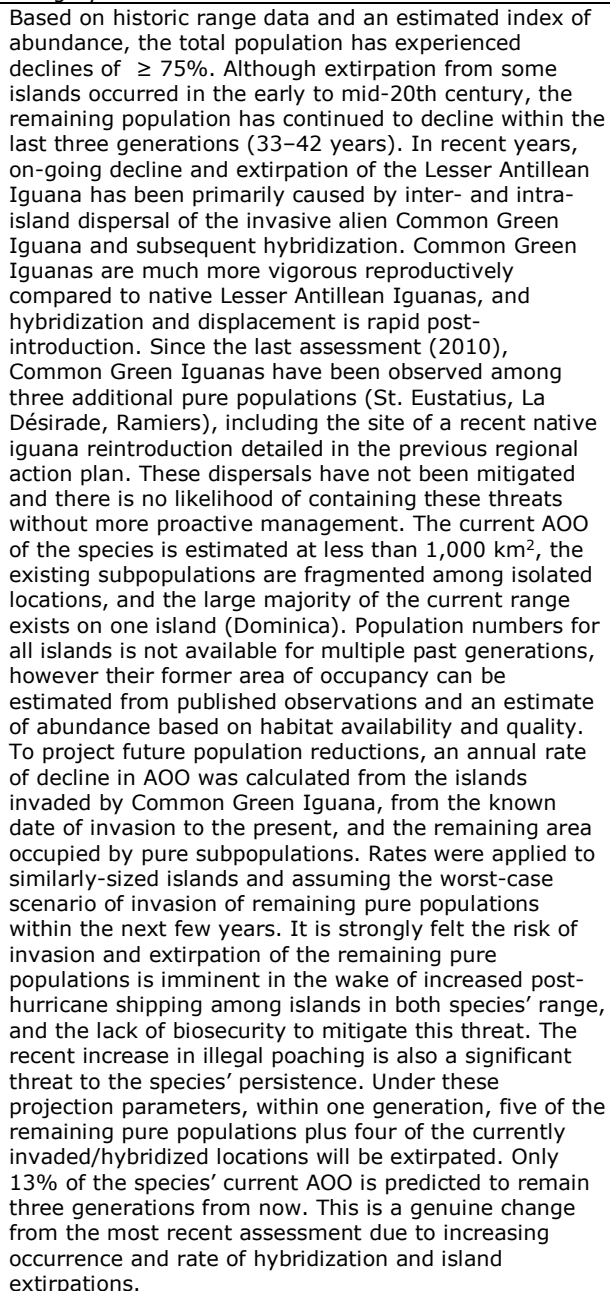 \\
\hline Pholidoscelis erythrocephalus (Shaw, 1802) & $\begin{array}{l}\text { St. } \\
\text { Christopher } \\
\text { Ameiva }\end{array}$ & NT & \begin{tabular}{|l|}
$2015-$ \\
$07-23$
\end{tabular} & 3.1 & $\begin{array}{l}\text { Listed as Near Threatened on the basis that this species } \\
\text { is restricted to St. Christopher Bank, on three islands } \\
\text { each of which is considered a single location based on } \\
\text { an ongoing or potential threat from invasive mammals. }\end{array}$ \\
\hline
\end{tabular}




\begin{tabular}{|c|c|c|c|c|c|}
\hline & & & & & $\begin{array}{l}\text { Remnant subpopulations on St. Kitts and Nevis may } \\
\text { qualify as severely fragmented, although their long-term } \\
\text { survival suggests that these subpopulations are viable. } \\
\text { It is however not clear whether the species is subject to } \\
\text { ongoing declines in any area where it survives, and } \\
\text { while there is a potential risk from mongoose should the } \\
\text { species arrive on Sint Eustatius the lizard's long } \\
\text { persistence on the larger islands, where mongoose have } \\
\text { been present for more than a century, suggests that it is } \\
\text { unlikely to be driven to extinction. }\end{array}$ \\
\hline Pholidoscelis plei Duméril \& Bibron, 1839 & $\begin{array}{l}\text { Anguilla } \\
\text { Bank Ameiva }\end{array}$ & LC & $\begin{array}{l}2015- \\
07-23\end{array}$ & 3.1 & $\begin{array}{l}\text { Listed as Least Concern in spite of its somewhat } \\
\text { restricted distribution, constrained further on Sint } \\
\text { Martin/Saint Martin by the action of invasive species, on } \\
\text { the basis that this species is somewhat widespread on } \\
\text { several islands where mongoose are not established and } \\
\text { it is not subject to major threats. Although populations } \\
\text { are thought to be depressed in the presence of invasive } \\
\text { mammals, particularly rats, the species' long co- } \\
\text { existence with this species throughout its range } \\
\text { suggests that it is not at any particular risk of extinction. }\end{array}$ \\
\hline Sphaerodactylus sabanus Cochran, 1938 & $\begin{array}{l}\text { Saba Dwarf } \\
\text { Gecko }\end{array}$ & LC & $\begin{array}{l}2015- \\
07-23\end{array}$ & 3.1 & $\begin{array}{l}\text { Listed as Least Concern on the basis that this species is } \\
\text { cosmopolitan and often abundant on Sint Eustatius and } \\
\text { in areas of Saba with at least some leaf litter, and while } \\
\text { threats are poorly-known it is not thought be subject to } \\
\text { major threats at present. Little is known of the species' } \\
\text { status on the larger islands St. Kitts and Nevis, however } \\
\text { the fact of its survival on these highly degraded islands } \\
\text { suggests that the species is highly resilient in the face of } \\
\text { human impacts and pressures from invasive species. }\end{array}$ \\
\hline Sphaerodactylus sputator (Sparrman, 1784) & $\begin{array}{l}\text { Least Island } \\
\text { Gecko }\end{array}$ & LC & $\begin{array}{l}2015- \\
07-23\end{array}$ & 3.1 & $\begin{array}{l}\text { Listed as Least Concern as this species is rather } \\
\text { widespread on two island banks in the Lesser Antilles, it } \\
\text { is adaptable and sometimes common, and there are not } \\
\text { thought to be any major threats. There are early } \\
\text { indications that the species may be in decline on } \\
\text { Anguilla, and monitoring here is recommended to clarify } \\
\text { whether declines are occurring and to identify the } \\
\text { causes if so, but there appears to be no evidence of } \\
\text { more widespread declines. }\end{array}$ \\
\hline Spondylurus powelli Hedges \& Conn, 2012 & NA & EN & $\begin{array}{l}2015- \\
07-24\end{array}$ & 3.1 & $\begin{array}{l}\text { Provisionally listed as Endangered on the basis that this } \\
\text { species has a restricted extent of occurrence, it is known } \\
\text { from only four islands each treated here as a separate } \\
\text { location (and hypothesized that it once occurred on a } \\
\text { fifth), its extent of occurrence is } 855 \mathrm{~km}^{2} \text {, and there are } \\
\text { anecdotal reports of declines on Anguilla, the largest } \\
\text { island within its range. The threats to this species, which } \\
\text { is confined to islands from which mongoose are absent, } \\
\text { are however, poorly-understood, it is not known to be } \\
\text { subject to any threats on Tentemerre or St. Barths and } \\
\text { research is needed to confirm whether a genuine decline } \\
\text { is underway on Anguilla to confirm that this listing is } \\
\text { justified. }\end{array}$ \\
\hline Grand Total & & & & & 42 \\
\hline
\end{tabular}


Wageningen Marine Research

T +31(0)317480900

E: marine-research@wur.nl

www.wur.eu/marine-research

Visitors' address

- Ankerpark 271781 AG Den Helder

- Korringaweg 7, 4401 NT Yerseke

- Haringkade 1, 1976 CP IJmuiden
Wageningen Marine Research is the Netherlands research institute established to provide the scientific support that is essential for developing policies and innovation in respect of the marine environment, fishery activities, aquaculture and the maritime sector.

\section{Wageningen University \& Research:}

is specialised in the domain of healthy food and living environment.

\section{The Wageningen Marine Research vision}

'To explore the potential of marine nature to improve the quality of life'

\section{The Wageningen Marine Research mission}

- To conduct research with the aim of acquiring knowledge and offering advice on the sustainable management and use of marine and coastal areas.

- Wageningen Marine Research is an independent, leading scientific research institute

Wageningen Marine Research is part of the international knowledge organisation Wageningen UR (University \& Research centre). Within Wageningen UR, nine specialised research institutes of the Stichting Wageningen Research Foundation have joined forces with Wageningen University to help answer the most important questions in the domain of healthy food and living environment. 